\title{
The Sanders Site (41LR2): A Middle to Historic Caddo Settlement and Mound Center on the Red River in Lamar County, Texas
}

Timothy K. Perttula

Heritage Research Center, Stephen F. Austin State University

Bo Nelson

Heritage Research Center, Stephen F. Austin State University

Mark Walters

Heritage Research Center, Stephen F. Austin State University

Robert Z. Selden Jr.

Heritage Research Center, Stephen F. Austin State University

Follow this and additional works at: https://scholarworks.sfasu.edu/ita

Part of the American Material Culture Commons, Archaeological Anthropology Commons, Environmental Studies Commons, Other American Studies Commons, Other Arts and Humanities Commons, Other History of Art, Architecture, and Archaeology Commons, and the United States History Commons

Tell us how this article helped you.

This Article is brought to you for free and open access by the Center for Regional Heritage Research at SFA ScholarWorks. It has been accepted for inclusion in Index of Texas Archaeology: Open Access Gray Literature from the Lone Star State by an authorized editor of SFA ScholarWorks. For more information, please contact cdsscholarworks@sfasu.edu. 


\section{The Sanders Site (41LR2): A Middle to Historic Caddo Settlement and Mound}

Center on the Red River in Lamar County, Texas

\section{Creative Commons License}

\section{(c) (1) \&}

This work is licensed under a Creative Commons Attribution-NonCommercial 4.0 International License 


\title{
The Sanders Site (41LR2): A Middle to Historic Caddo Settlement and Mound Center on the Red River in Lamar County, Texas
}

\author{
Timothy K. Perttula, Bo Nelson, Mark Walters, and Robert Z. Selden Jr.
}

\section{INTRODUCTION}

The T. M. Sanders site (41LR2) is one of the more important (although still not well known or intensively studied) ancestral Caddo sites known in East Texas (Figure 1), primarily because of its two earthen mounds (Figure 2) and the well-preserved mortuary features of Caddo elite persons buried in Mound No. 1 (the East Mound). Archaeological work began at the site in 1931 by The University of Texas at Austin (Chelf 1939; Jackson et al. 2000; Pearce and Jackson 1931), with sporadic work by members of the Dallas Archeological Society in the 1940s and 1950s (Hanna 1950; Harris 1953; Housewright 1940; Wilson 1948; Wilson and Housewright 1941). Archaeological and bioarchaeological interpretations of the findings from this work at the Sanders site began with Krieger's analyses $(1946,2000,2009)$ of the burial features and associated funerary objects (including marine shell gorgets, shell beads, arrow points, and ceramic vessels). These analyses and studies continue to the present day, and rely upon the reanalysis and reinterpretation of the archaeological (Bruseth et al. 1995; Hamilton 1997; Jurney and Young 1995; Perttula 1997, 2013; Schambach 1995, 1999, 2000a, 2000b) and bioarchaeological (Maples 1962; Wilson 1993, 1994, 1995, 1997; Wilson and Cargill 1993; Wilson and Derrick 1996) materials recovered in the Pearce and Jackson (1931) and Jackson et al. (2000) work.

Although the Sanders site is not dated by radiocarbon analyses, the general consensus is that the main Caddo occupation took place around ca. A.D. 1100-1300 (see Bruseth 1998), contemporaneous with related sites downstream along the Red River near its confluence with the Kiamichi River, and other sites in the Sabine River basin (see Krieger 1946, 2009). A late 17th-early 18th century Caddo occupation is also present at the Sanders site, but remains poorly known (e.g., Bell et al. 1967:Figure 1; Harris et al. 1965:288; Harris and Harris 1967:131). Harris and Harris (1967:131) commented that European "trade material is exceptionally scarce" at the Sanders site, but they do note that 478 glass beads had been found at the site. Harris (1953:20) had previously stated that several Caddo burials with European trade goods had been found along Bois d'Arc Creek south of Mound No. 2, the larger or West Mound (see Figure 2).

According to Edward B. Jelks (personal communication, May 25, 2014), an Historic Caddo area investigated by Lester Wilson (an avocational archaeologist from Wylie, Texas) was about $100 \mathrm{~m}$ south of the two mounds at the Sanders site. This may be one of the areas identified by Jackson (n.d.:74) between ca. 90-150 m south of the mounds where he noted concentrations of triangular arrow points, small end scrapers, flint awls, and other stone tools. A 1971 map in the TARL files drawn by Dee Ann Story locates the historic Caddo settlement east of Bois d'Arc Creek and south of Mound No. 2.

\section{SETTING}

The Sanders site is located on a broad alluvial terrace just south of the confluence of Bois d'Arc Creek and the Red River. The terrace has Caspiana silt loam soils (Ressel 1979:52), which have a shallow dark brown silt loam A-horizon overlying thick B- and C-horizons that range from dark reddish-brown, reddish-brown, dark brown, to yellowish-red in color. These soils formed in loamy alluvial sediments of the Red River. 


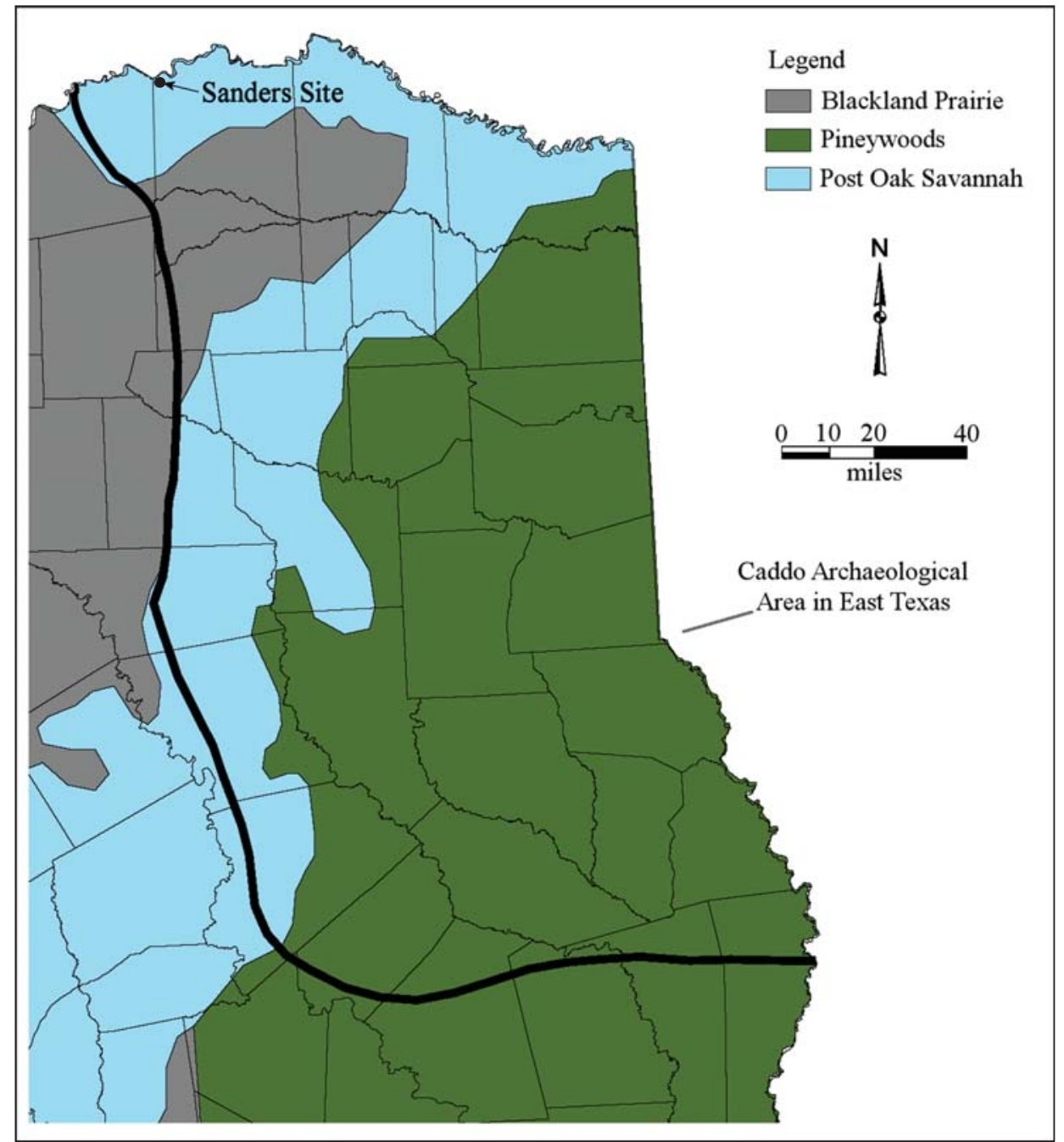

Figure 1. The location of the Sanders site (41LR2) in Lamar County in East Texas.

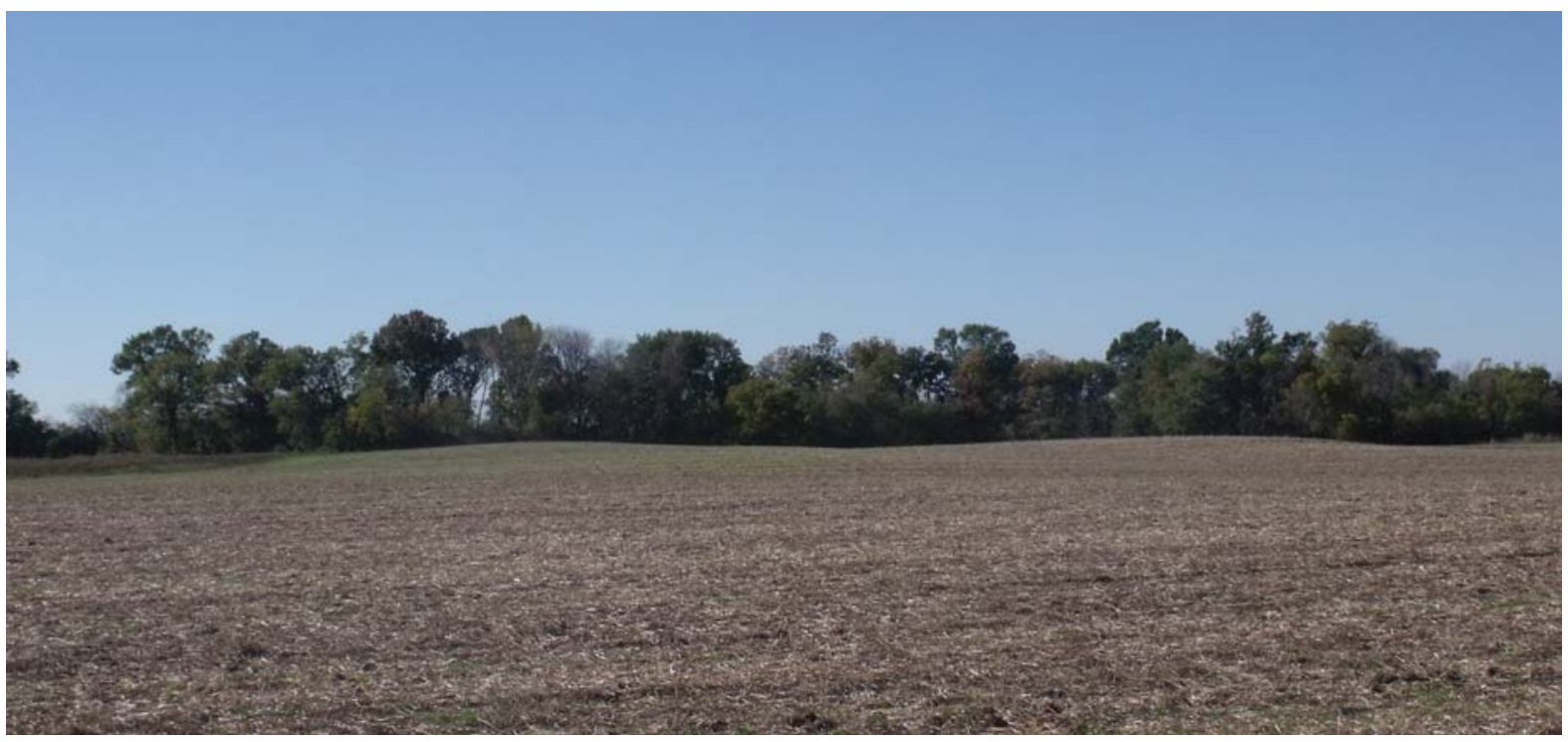

Figure 2. Looking north at Mound No. 1 (east) and Mound No. 2 (west) in November 2013. 


\section{CURRENT ARCHAEOLOGICAL INVESTIGATIONS}

The archaeological investigations at the Sanders site that we report on were conducted in March 2014, just before crops were planted across the lands owned by Julia Trigg Crawford. No work was conducted on the portion of the Sanders site owned by the Sanders family.

The Crawford lands were plowed at the time of the archaeological investigations, with excellent surface visibility (Figure 3). This dictated the nature of the archaeological work, which focused on the recognition and delineation of clusters of prehistoric artifacts on the surface of the site, and the obtaining of samples of artifacts from each of the defined surface clusters/surface collection areas. It had been planned that shovel tests would be excavated in each of the defined surface collection areas, but the soils were much too wet to effectively excavate and screen the soil matrix in the few shovel tests that were completed during the work.

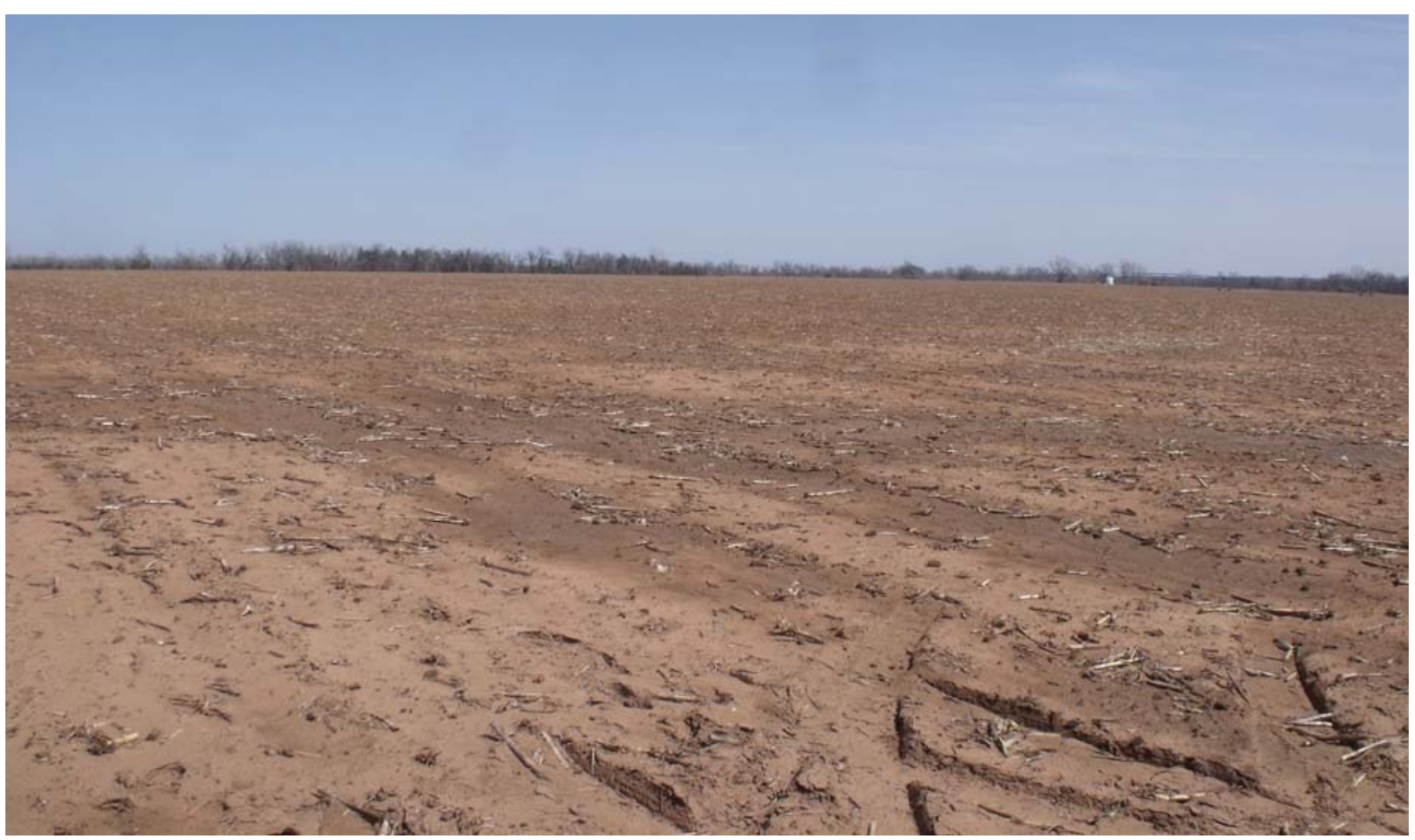

Figure 3. Looking east across the Crawford property, March 2014.

Due to the very wet and muddy conditions in the fields, the surface investigations were confined to the higher portions of the site where we documented areas of concentrations of surface artifacts. The method of documentation consisted of walking along until several artifacts were observed on the surface, and at that point, a flag was placed at the artifacts, and a GPS reading was taken. Once a flag was placed, artifacts were collected as far as the extent of visible material was present. Usually, the artifactual materials would extend from 10 to $30 \mathrm{~m}$ from the flag before becoming sparse to no artifacts being observed on the surface. The process was repeated until an artificial or natural boundary was reached in the fields. Basically, all observable surface artifacts were collected within an area.

The areas and artifacts collected were the higher portions of the fields at an elevation of approximately $450 \mathrm{ft}$ amsl. The higher areas contained soils of Caspiana silt loams surrounded by Redlake clays. The artifacts did not seem to extend into the clay soils. The northern portion of the fields near the intersection of Bois D'Arc Creek and the Red River contain some areas of silt loam and very fine sandy loam soils, and these were examined, but no surface artifacts were observed. These northern soils may be too recent in age, and subject to flooding episodes, to have surface artifacts. 
Future plans for archaeological investigations at the Sanders site include the excavation of shovel tests in each of the surface collection areas when the sediments are drier and can be more easily screened through 1/4-inch mesh. In conjunction with this will be a geophysical survey of the extensive habitation areas at the Sanders site to identify structural anomalies and other cultural features.

\section{Surface Collection Areas}

Clusters of artifacts were located during the surface inspection of the Sanders site, and the extent and spatial centroids of these surface collection areas was established with a GPS. A total of 33 surface collection areas have been established at the Sanders site, three on the Sanders family part of the site (Surface Collection Area 3 and the East [Mound No. 1] and West [Mound No. 2] Mounds) and 30 on the Crawford part of the site (Figure 4).

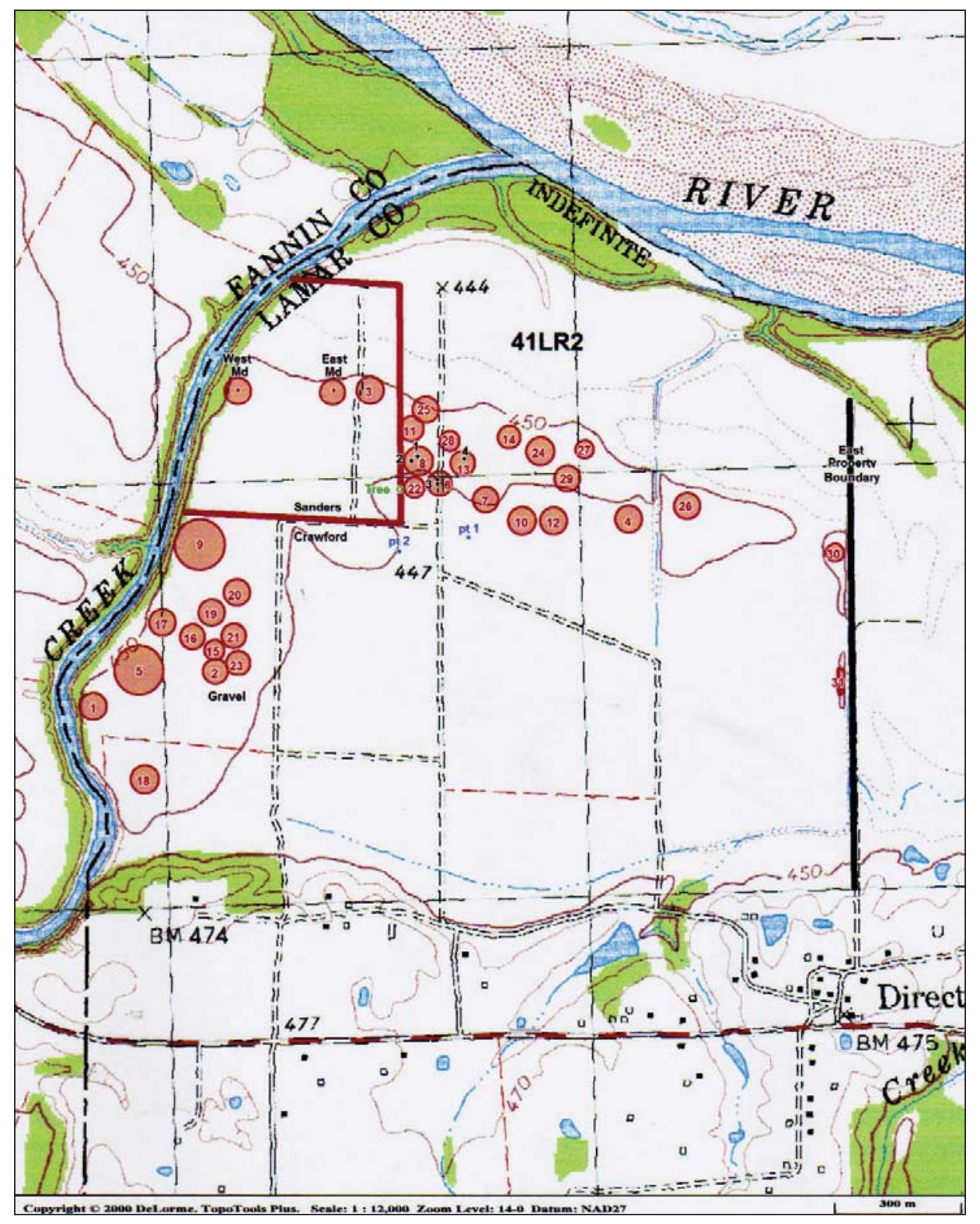

Figure 4. Surface collection areas on the Sanders site. 
These surface collection areas are situated on an alluvial terrace of the Red River that sits at 450 feet amsl. They are distributed both south and east of the East and West Mounds, extending approximately 1260 $\mathrm{m}$ east from the East Mound and approximately $960 \mathrm{~m}$ south of the West Mound (Figure 5), an area of approximately 470 acres, with distinctive clusters of surface collected artifacts beginning close to both mounds. This extensive distribution of artifacts indicates that there is an extensive ancestral Caddo settlement at the site, not just two earthen mounds and a midden area between them (see Krieger 1946:Figure 9).

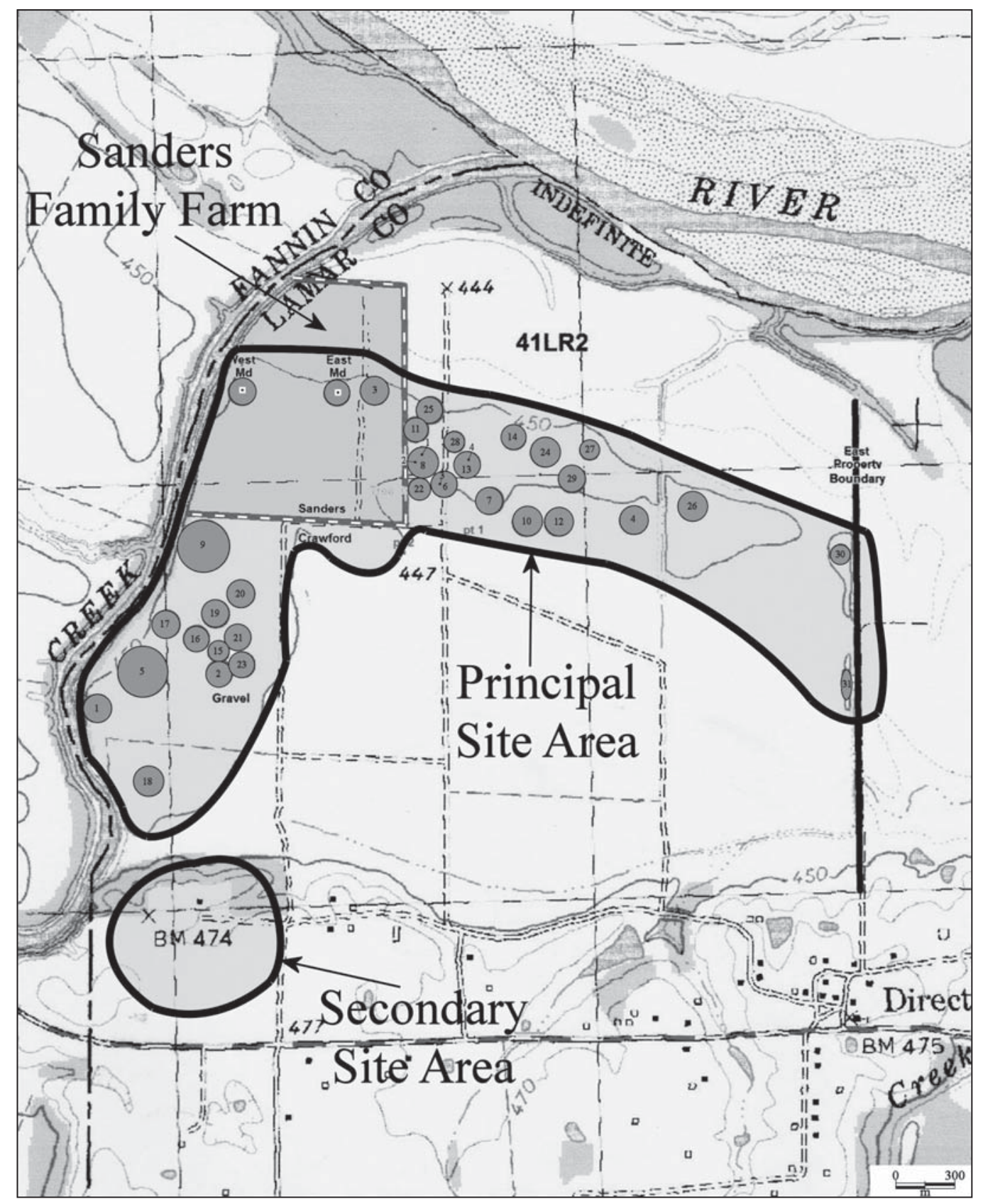

Figure 5. Principal site area of the Sanders site.

There is a small secondary area of the Sanders site on a higher alluvial terrace (474 ft. amsl) that overlooks the principal site area (see Perttula and Marceaux 2011; Peyton 2013) (see Figure 5). Ancestral Caddo ceramic sherds and other artifacts occur in low densities on this landform. 


\section{Shovel Tests}

Four shovel tests were excavated at the Sanders site during the most recent archaeological investigations at the site, including ST 1 and ST 2 in Surface Collection Area 8, ST 3 in Surface Collection Area 6, and ST 4 in Surface Collection 13 (see Figure 4). Midden deposits were encountered in each of the shovel tests. Shovel tests \#1 and ST 2 were excavated where darker soils, animal bone pieces, and mussel shell fragments were present on the surface within Area 8. Shovel tests \#3 and ST 4 were excavated within adjacent surface collection areas.

The A-horizon silt loam with midden deposits (Figure 6) ranges from $23-45 \mathrm{~cm}$ in thickness, with the thickest deposits in ST 1 in Surface Collection Area 8. The A-horizon overlies either a reddish-brown silt loam or a dark yellowish-brown silt loam. The shovel tests contain moderate densities of ceramic sherds, lithic debris, animal bone, and mussel shell fragments (Table 1), along with flecks of charcoal. Artifact densities average 6.75 sherds per shovel test (ca. 54 sherds per square meter), 0.75 lithic tools per shovel test (ca. 6.0 tools per square meter), 3.5 pieces of lithic debris per shovel test (ca. 28 pieces of lithic debris per square meter), and 5.0 pieces of animal bone/mussel shell per shovel test (ca. 40 pieces per square meter). The total mean artifact density per shovel test is 16.0, or ca. 128 artifacts per square meter in these Surface Collection areas; the highest artifact densities are in ST $1(n=23)$ and ST $4(n=19)$.

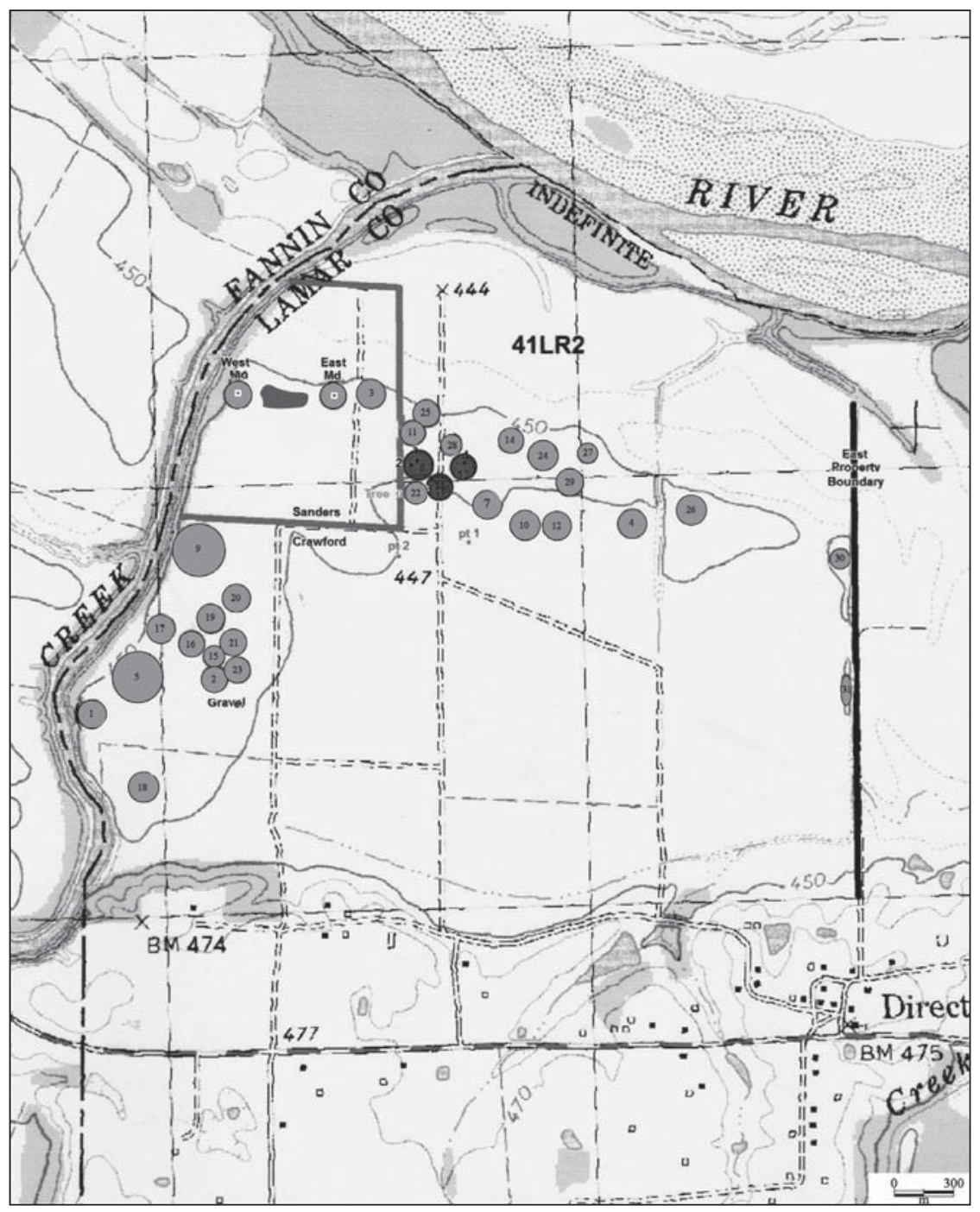

Figure 6. Known midden areas (shaded in black) at the Sanders site. 
Table 1. Artifacts recovered in the 2014 shovel tests at the Sanders site.

\begin{tabular}{lcccc}
\hline $\begin{array}{l}\text { ST and depth } \\
\text { (cm bs) }\end{array}$ & Sherds & $\begin{array}{c}\text { Lithic } \\
\text { tools }\end{array}$ & $\begin{array}{c}\text { Lithic } \\
\text { debris }\end{array}$ & $\begin{array}{c}\text { Animal/mussel } \\
\text { bone/shell }\end{array}$ \\
\hline ST 1, 0-20 & 2 & - & 6 & 2 \\
ST 1, 20-40 & 5 & - & - & 2 \\
ST 1, 40-60 & 1 & - & 1 & 4 \\
Subtotal & 8 & - & 7 & 8 \\
ST 2, 0-20 & 9 & - & 4 & 2 \\
ST 2, 20-40 & - & - & 1 & - \\
Subtotal & 9 & - & 5 & 1 \\
ST3, 0-20 & - & - & 2 & 2 \\
ST 3, 20-40 & 2 & - & - & - \\
Subtotal & 2 & 1 & - & 8 \\
ST 4, 0-20 & 3 & 2 & - & 20 \\
ST 4, 20-40 & 5 & 3 & 14 & \\
Subtotal & 8 & 3 & & \\
\hline Totals & 27 & & & \\
\hline
\end{tabular}

A soil probe was used in the approximate center of Area 5 in an area of some darker surface soils, and at 23-44 cm bs, a lens of possible midden soils was encountered. A shovel test was not attempted at the time, because of the wet soils, but will be a possible location for future shovel tests.

\section{ARTIFACT ASSEMBLAGE}

The recovered artifact assemblage from the 2014 shovel testing and surface collection investigations include both ancestral Caddo ceramic and lithic artifacts. Our 2014 collections include 1689 ceramic sherdsabout 10 percent of which have decorative elements - 151 chipped stone tools (primarily expedient flake tools, scrapers, and arrow points), lithic debris ( $\mathrm{n}=513$ from both shovel tests and surface collection areas), a possible gunflint, a ground stone celt, and animal bones/mussel shell fragments $(n=32)$.

\section{Ceramic Sherds}

A total of 1689 ceramic sherds were collected from four shovel tests and numerous surface collection areas (Table 2). The surface collection areas with the highest numbers of sherds are concentrated east and southeast of the East Mound, and ca. 300 m south of the West Mound, overlooking Bois d'Arc Creek (Figure 7). 
Table 2. Ceramic Sherds by 2014 Surface Collection Areas and Shovel Tests.

\begin{tabular}{|c|c|c|c|c|}
\hline Provenience & $\begin{array}{c}\text { Grog- } \\
\text { tempered }\end{array}$ & $\begin{array}{l}\text { Bone- } \\
\text { tempered }\end{array}$ & $\begin{array}{c}\text { Shell- } \\
\text { tempered }\end{array}$ & $\mathrm{N}$ \\
\hline ST 1 & 1 & 1 & 4 & 6 \\
\hline ST 2 & 8 & - & 1 & 9 \\
\hline ST 3 & 2 & - & - & 2 \\
\hline ST 4 & 4 & 3 & 1 & 8 \\
\hline Area 4 & 6 & - & - & 6 \\
\hline Area 5 & 40 & 1 & 3 & 44 \\
\hline Area 6 & 115 & 25 & 27 & 167 \\
\hline Area 7 & 121 & 10 & 39 & 170 \\
\hline Area 8 & 210 & 12 & 30 & 252 \\
\hline Area 9 & 314 & 48 & 60 & 422 \\
\hline Area 10 & 49 & 6 & 4 & 59 \\
\hline Area 11 & 36 & 3 & 14 & 53 \\
\hline Area 12 & 41 & 1 & - & 42 \\
\hline Area 13 & 75 & 20 & 12 & 107 \\
\hline Area 14 & 35 & 6 & 1 & 42 \\
\hline Area 15 & 7 & 1 & - & 8 \\
\hline Area 16 & 33 & 2 & 2 & 37 \\
\hline Area 17 & 4 & - & - & 4 \\
\hline Area 18 & 4 & 2 & 1 & 7 \\
\hline Area 19 & 10 & 3 & 2 & 15 \\
\hline Area 20 & 15 & 4 & 5 & 24 \\
\hline Area 21 & 21 & 1 & 3 & 25 \\
\hline Area 22 & 17 & 1 & 5 & 23 \\
\hline Area 23 & 17 & - & 7 & 24 \\
\hline Area 24 & 29 & 8 & 7 & 44 \\
\hline Area 25 & 15 & 5 & 2 & 22 \\
\hline Area 26 & 17 & 14 & 1 & 32 \\
\hline Area 27 & 1 & - & 3 & 4 \\
\hline Area 28 & 3 & - & 2 & 5 \\
\hline Area 29 & 14 & 1 & - & 15 \\
\hline Area 30 & 5 & 2 & 1 & 8 \\
\hline Area 31 & 3 & - & - & 3 \\
\hline Totals & 1272 & 180 & 237 & 1689 \\
\hline
\end{tabular}

About 75 percent of the sherds are from vessels tempered with grog. Another 11 percent are from bonetempered vessels, and the remaining 14 percent are from shell-tempered vessels (see Table 2). The surface collection areas with the highest proportion of grog-tempered sherds are both east-southeast ca. 250-500 $\mathrm{m}$ from the East Mound and ca. 480-720 m south of the West Mound, near Bois d'Arc Creek (Figure 8). The bone-tempered sherds have a similar distribution, although one surface collection area with a higher proportion of bone-tempered sherds is ca. $840 \mathrm{~m}$ southeast of the East Mound (Figure 9). The surface collection areas with the highest proportion of shell-tempered sherds are in the areas east and southeast of the East Mound and well south of the West Mound near Bois d'Arc Creek (Figure 10). 


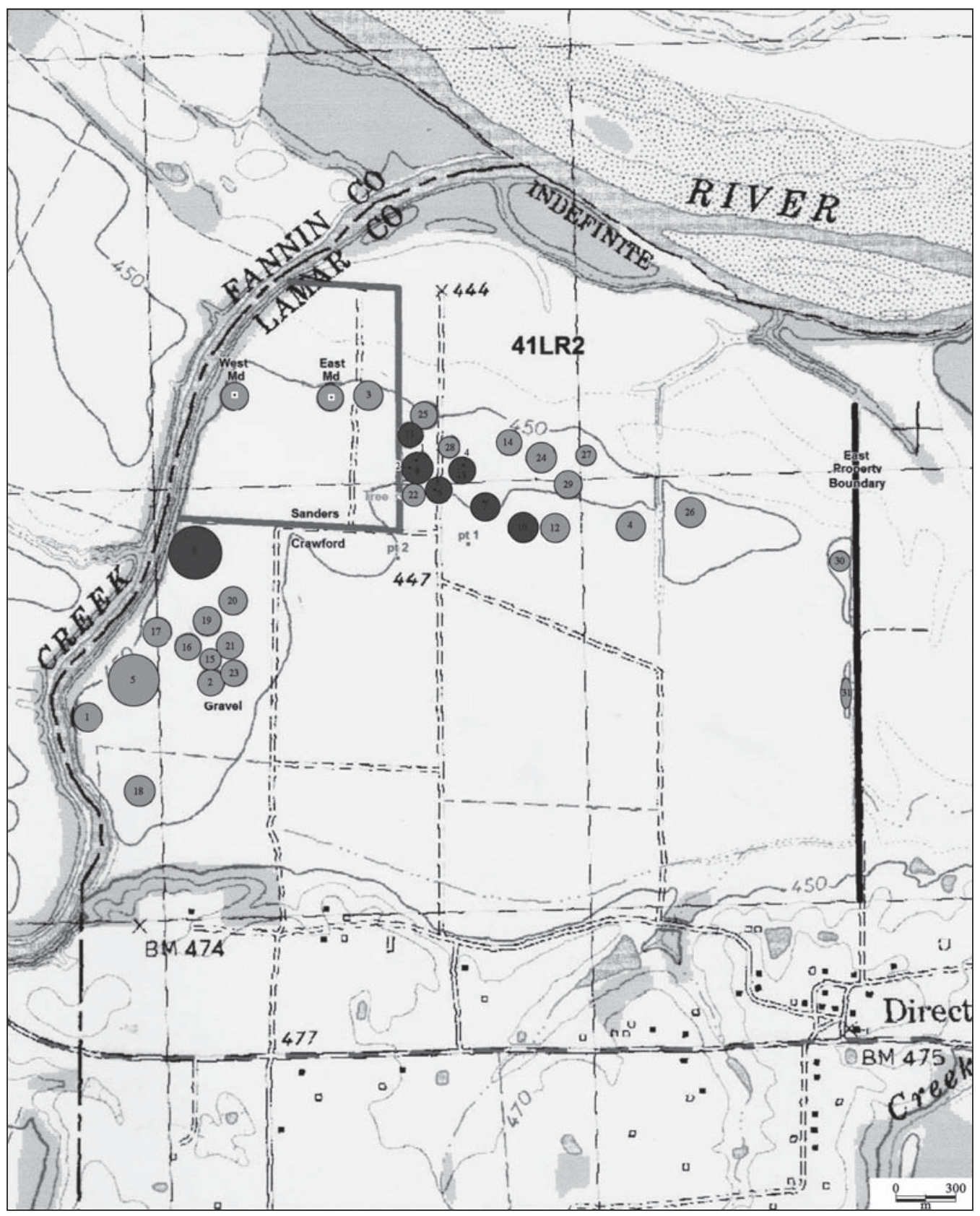

Figure 7. Surface collection areas with the highest numbers of Caddo ceramic sherds, shaded in black.

Although the seven surface collection areas with the highest proportion of shell-tempered sherds are clustered in two parts of the site (see Figure 10), the overall distribution of shell-tempered sherds is far from clustered. In fact, sherds from shell-tempered vessels occur in almost every surface collection area, and are widely distributed across the site: on the mounds, east and southeast of the East Mound, and well south of the West Mound, alongside Bois d'Arc Creek (Figure 11).

Only 10 percent of the sherds from the Sanders site have decorations (Table 3 ). The site's overall plain to decorated ratio is a very high 8.94 , indicating that plain wares are very well-represented in the ceramic assemblage. Between 11-12 percent of the grog- and bone-tempered sherds are decorated, compared to only 4 percent of the shell-tempered sherds. This difference suggests not only that the three distinct tempered 


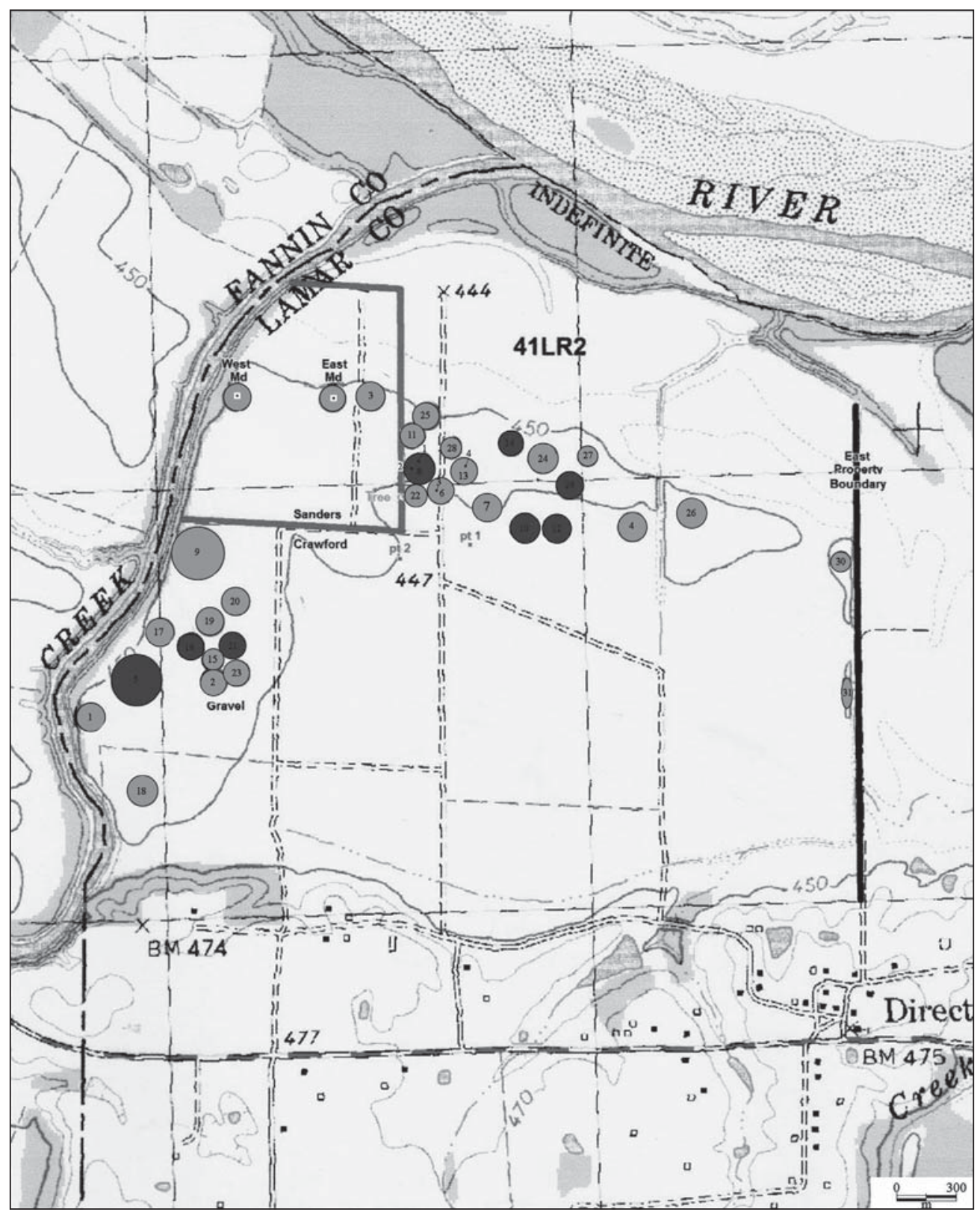

Figure 8. Distribution of surface collection areas at the Sanders site with the highest proportion of grog-tempered sherds, shaded in black.

wares are represented by different proportions of plain versus decorated vessels, but also by differences in the frequency with which decoration of vessels occurs on their rim and/or body sections.

Utility ware sherds (i.e., those with wet paste decorations, such as brushed, incised, punctated, etc.) comprise only 33 percent of the decorated sherd assemblage (see Table 3). This proportion varies from 31 percent for grog-tempered sherds, 40 percent for shell-tempered sherds, and 45 percent for bone-tempered sherds. The most common utility ware sherds have incised, appliqued, fingernail punctated, and neck banded decorative elements.

Fine ware sherds (i.e., those decorated after the vessel was leather hard or fired, such as engraved and red-slipped; trailed sherds are included because the design element indicates it is from a Keno Trailed vessel 


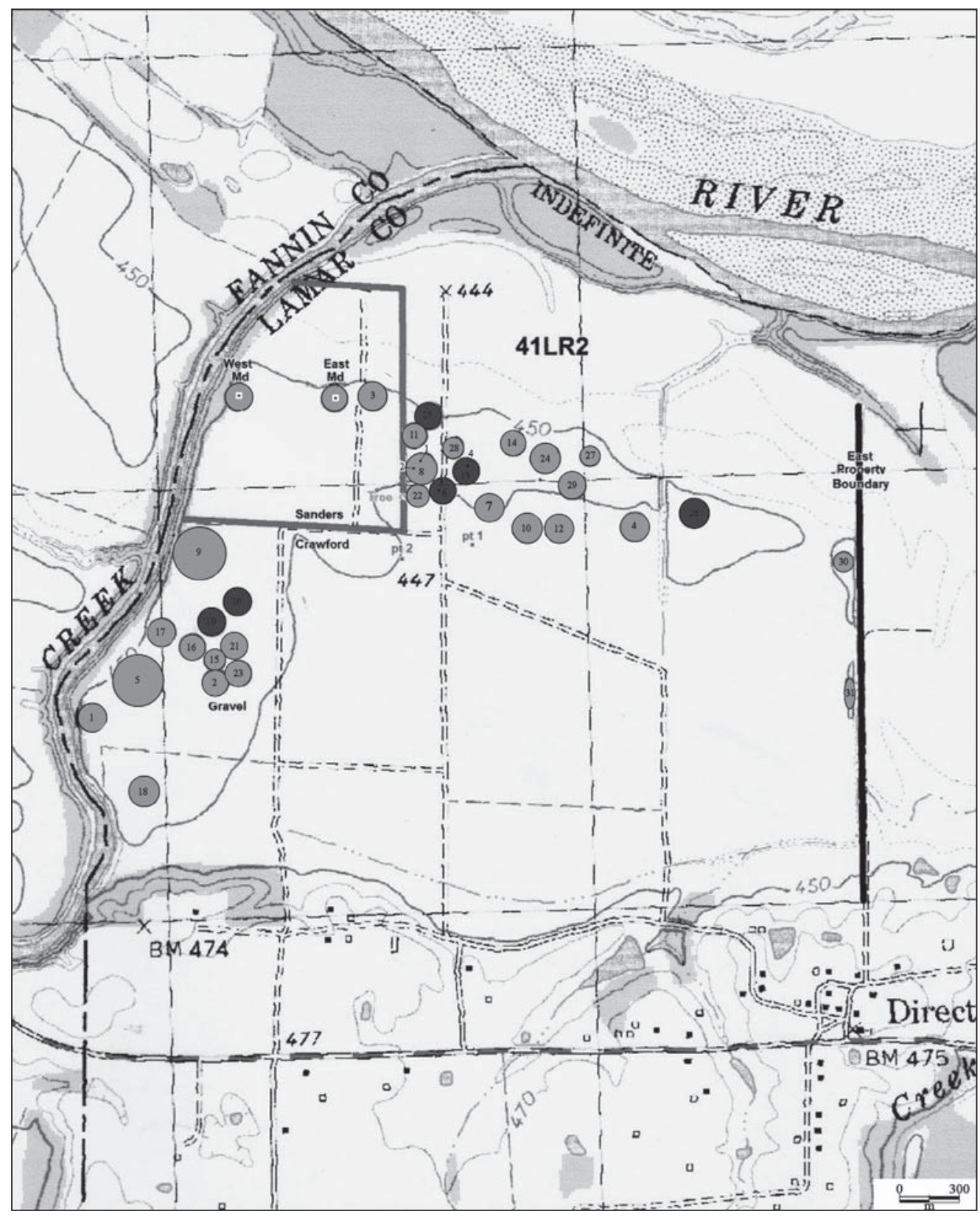

Figure 9. Distribution of surface collection areas at the Sanders site with the highest proportion of bone-tempered sherds, shaded in black.

with a fine ware shape) comprise an impressive 67 percent of all the decorated sherds (see Table 3), with proportions ranging from 55 percent for bone-tempered sherds, 60 percent for shell-tempered sherds, and 69 percent for grog-tempered sherds. The sherds with engraved decorative elements account for 76 percent of the fine wares; 0.9 percent of the fine wares are engraved-punctated; 22 percent are red-slipped; and 0.9 percent are trailed (Keno Trailed).

There is a wide variety of decorative elements in the utility wares from the 2014 surface collection at the Sanders site (Table 4). These include appliqued (14.3 percent), brushed (3.6 percent), incised (44.6 percent), neck banded ( 8.9 percent), and punctated ( 26.8 percent) decorative methods. 


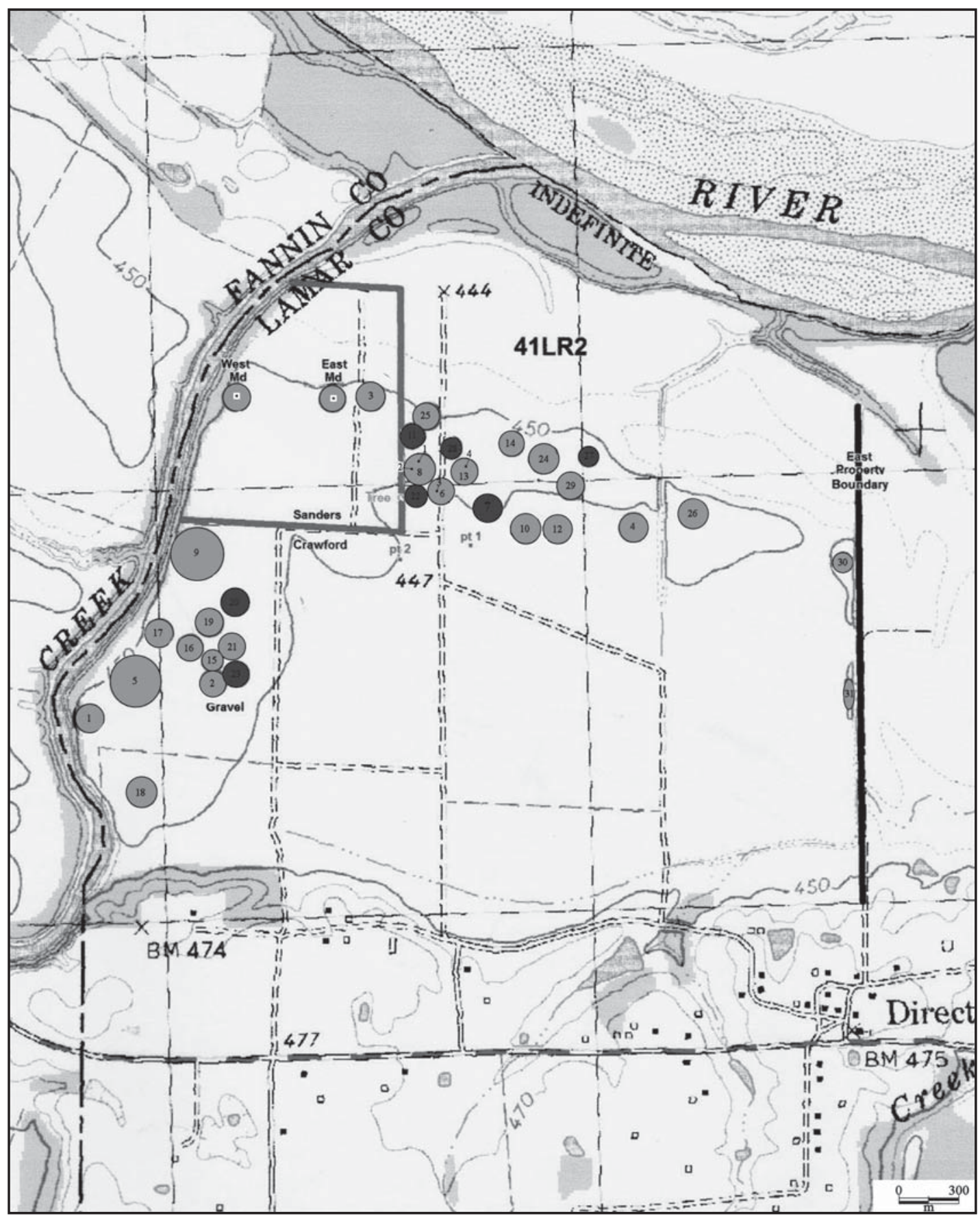

Figure 10. Distribution of surface collection areas at the Sanders site with the highest proportion of shell-tempered sherds, shaded in black.

The appliqued body sherds have either nodes or fillets/ridges (see Table 4). These may be from McKinney Plain jars (see Suhm and Jelks 1962:97), but it is more likely they are body decorative elements on grog- and shell-tempered varieties of Nash Neck Banded (see Krieger 2000:141-142) ${ }^{1}$. The two grog-tempered brushed sherds in the utility ware sherds are probably from Bullard Brushed vessels made by Middle or Late Caddo potters in the upper Sabine and upper Cypress stream basins, as brushed utility wares do not appear to be a characteristic of the ceramics made at the Sanders site (see Krieger 1946, 2000). 


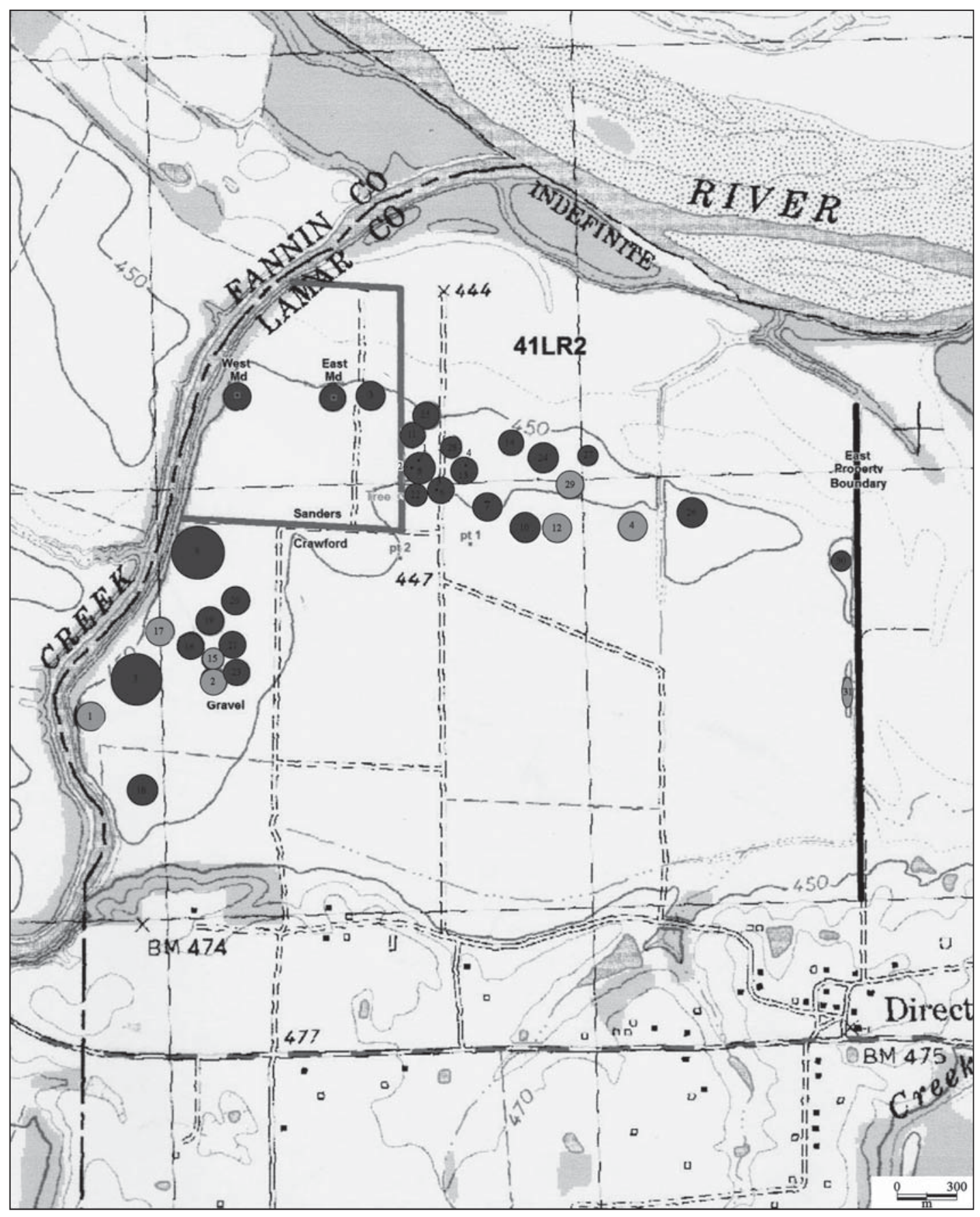

Figure 11. Distribution of surface collection areas with shell-tempered sherds at the Sanders site, shaded in black.

The 24 grog- and bone-tempered incised rim and body sherds are probably from Canton Incised vessels, except for the bowl rim with horizontal incised lines (see Table 4). These latter sherds are probably from Davis Incised or Dunkin Incised vessels. The other incised decorative elements represented include cross-hatched lines (see Suhm and Jelks 1962:Plate 12c), diagonal opposed lines (Figure 12a; see Suhm and Jelks 1962:Plate 12f-g), horizontal and diagonal opposed lines, horizontal and vertical lines (Figure 12b), and opposed lines (see Suhm and Jelks 1962:Plate 12a). 
Table 3. Decorated sherds by decorative method and temper classes in the 2014 surface collection.

\begin{tabular}{|c|c|c|c|c|}
\hline Decorative method & $\begin{array}{c}\text { Grog- } \\
\text { tempered }\end{array}$ & $\begin{array}{c}\text { Bone- } \\
\text { tempered }\end{array}$ & $\begin{array}{c}\text { Shell- } \\
\text { tempered }\end{array}$ & $\mathrm{N}$ \\
\hline \multicolumn{5}{|l|}{ Utility ware } \\
\hline Appliqued & 5 & 1 & 3 & 9 \\
\hline Brushed & 1 & 1 & - & 2 \\
\hline Incised & 19 & 5 & 1 & 25 \\
\hline Neck banded & 4 & 1 & - & 5 \\
\hline Punctated, cane & 1 & - & - & 1 \\
\hline Punctated, circular & 3 & - & - & 3 \\
\hline Punctated, fingernail & 6 & 1 & - & 7 \\
\hline Punctated, tool & 3 & 1 & - & 4 \\
\hline Subtotal & 42 & 10 & 4 & 56 \\
\hline \multicolumn{5}{|l|}{ Fine ware } \\
\hline Engraved & 72 & 10 & 3 & 85 \\
\hline Engraved-punctated & 1 & - & - & 1 \\
\hline Red-slipped & 20 & 2 & 3 & 25 \\
\hline Trailed & 1 & - & - & 1 \\
\hline Subtotal & 94 & 12 & 6 & 112 \\
\hline Totals & 136 & 22 & 10 & 168 \\
\hline
\end{tabular}

Table 4. Decorative elements in utility wares from the Sanders site 2014 surface collection.

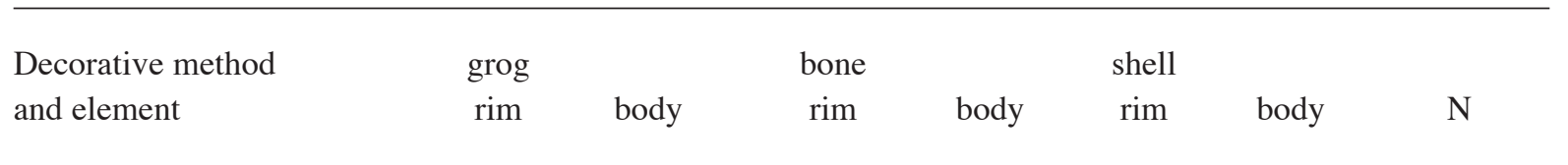

\section{Appliqued}

nodes

parallel fillets

parallel ridges

straight fillet

straight ridge

Subtotal

$\begin{array}{lll}- & - & - \\ - & 1 \\ - & 1 \\ - & 2 \\ - & 1 \\ - & 5\end{array}$

-
-
-
-
-
-

1
-
-
-
-
1

-
-
-
-
-

2

3

\section{Brushed}

horizontal and diagonal

1

brushing marks

parallel brushing marks

Subtotal

$-$

Incised

cross-hatched lines

curvilinear line

diagonal opposed lines

$\begin{array}{ll}- & 1 \\ - & 1 \\ - & 3\end{array}$

$-$

$-$

$-$

-
-
-

-
-
-

$\begin{array}{ll}- & 1 \\ - & 1 \\ - & 3\end{array}$


Table 4. Decorative elements in utility wares from the Sanders site 2014 surface collection, cont.

\begin{tabular}{|c|c|c|c|c|c|c|c|}
\hline $\begin{array}{l}\text { Decorative method } \\
\text { and element }\end{array}$ & $\begin{array}{l}\text { grog } \\
\text { rim }\end{array}$ & body & $\begin{array}{l}\text { bone } \\
\text { rim }\end{array}$ & body & $\begin{array}{l}\text { shell } \\
\text { rim }\end{array}$ & body & $\mathrm{N}$ \\
\hline horizontal line & 1 & - & - & - & - & - & 1 \\
\hline $\begin{array}{l}\text { horizontal and diagonal } \\
\text { opposed lines }\end{array}$ & - & 1 & - & - & - & - & 1 \\
\hline $\begin{array}{l}\text { horizontal and vertical } \\
\text { lines }\end{array}$ & 1 & - & - & - & - & - & 1 \\
\hline opposed lines & - & 1 & - & 1 & - & - & 2 \\
\hline parallel lines & - & 9 & - & 2 & - & 1 & 12 \\
\hline straight line & - & 1 & - & 2 & - & - & 3 \\
\hline Subtotal & 2 & 17 & - & 5 & - & 1 & 25 \\
\hline \multicolumn{8}{|l|}{ Neck Banded } \\
\hline horizontal bands & 2 & - & - & - & - & - & 2 \\
\hline parallel neck bands & - & 2 & - & 1 & - & - & 3 \\
\hline Subtotal & 2 & 2 & - & 1 & - & - & 5 \\
\hline \multicolumn{8}{|l|}{ Punctated } \\
\hline cane punctated rows & - & 1 & - & - & - & - & 1 \\
\hline circular punctated row & - & 3 & - & - & - & - & 3 \\
\hline fingernail punctated row & 1 & 4 & - & 1 & - & - & 6 \\
\hline fingernail punctate, single & - & 1 & - & - & - & - & 1 \\
\hline linear tool punctated row & - & 1 & - & - & - & - & 1 \\
\hline tool punctated row & - & 1 & - & - & - & - & 1 \\
\hline tool punctate, single & - & 1 & - & 1 & - & - & 2 \\
\hline Subtotal & 1 & 12 & - & 2 & - & - & 15 \\
\hline Totals & 6 & 37 & - & 9 & - & 4 & 56 \\
\hline
\end{tabular}

One incised body sherd with parallel lines is from a shell-tempered vessel (see Table 4). It may be from the body of a Late to Historic Caddo Emory Punctated-Incised jar. When incising is present on these vessels, "it usually consists of straight to slightly curved lines extending from below the rim to the base or to about the middle of the body. Punctations are often combined with either incising or brushing" (Story et al. 1967:137).

The few grog- and bone-tempered neck banded sherds have horizontal rows of neck bands on the rim of utility ware jars. These sherds are from non-shell-tempered varieties of Nash Neck Banded. According to Krieger (2000:141), about 57 percent of the neck banded sherd/vessel batches in the Sanders site he analyzed had grog, sand/tuff, or bone temper; the remaining 43 percent had a fine shell temper. None of the neck banded vessel batches were recovered in the Mound No. 1 burials (Krieger 2000:Table 50), and apparently are from non-mound midden deposits trenched by UT in 1931.

The sherds with punctated decorative elements are from grog- and bone-tempered vessels that have one or more rows of punctations on the rim and/or the body of utility ware jars (see Table 4). This includes cane (7 percent), large circular tool (20 percent), fingernail (47 percent), and tool/dowel (27 percent) punctations. 


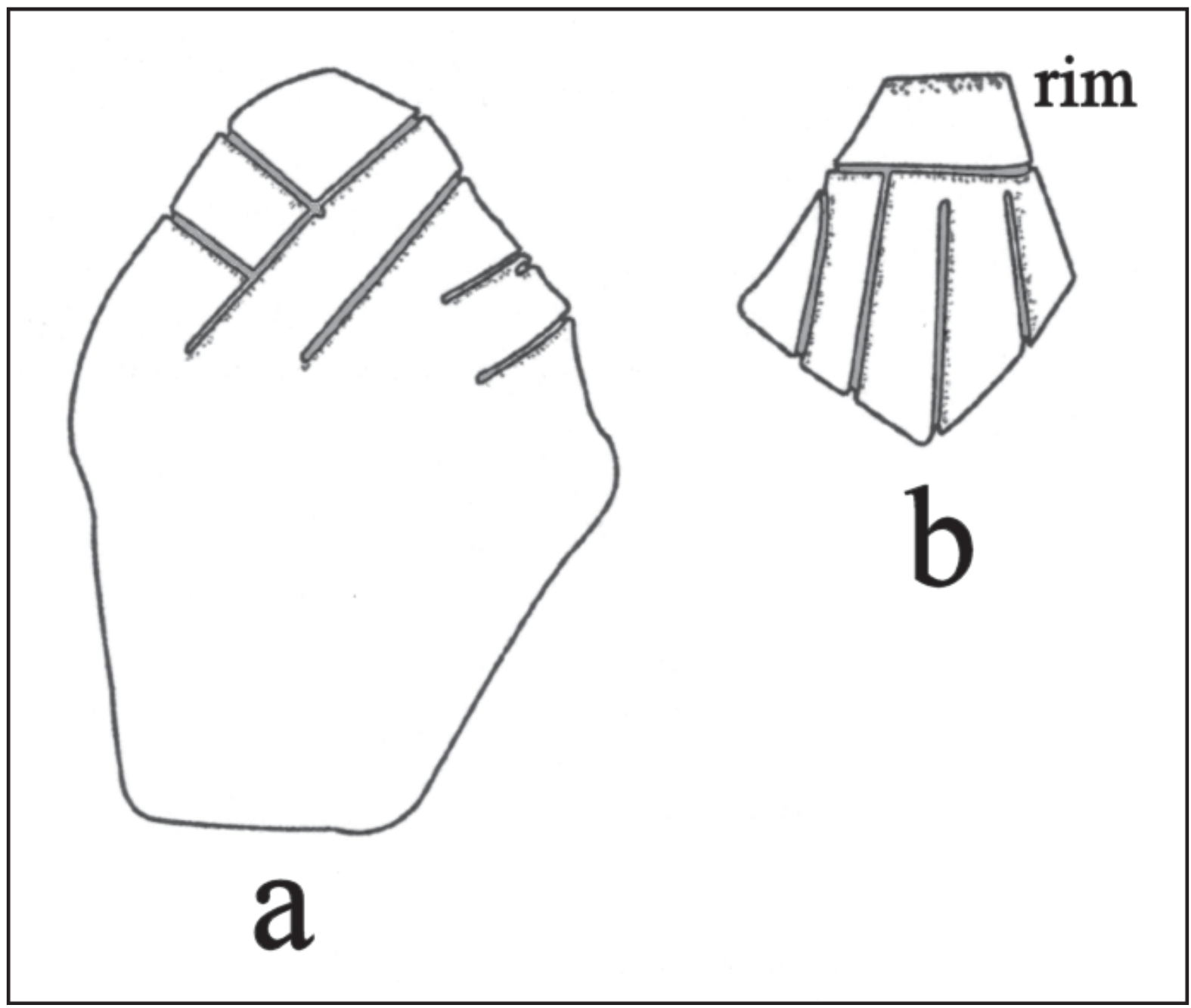

Figure 12. Incised rim and body sherds from the Sanders site: a, Area 6; b, Area 8.

The fingernail punctated rim and body sherds are from Monkstown Fingernail Impressed jars (see Suhm and Jelks 1962:Plate 55). The other punctated sherds may be from undefined punctated wares in the assemblage, or varieties of Monkstown where the punctations are executed with wood or cane tools rather than fingernail impressions.

The many decorative elements represented in the fine wares from the 2014 surface collection areas at the Sanders site are listed in Table 5. About 95 percent of the fine ware sherds are from grog- and bonetempered vessels.

Table 5. Decorative elements in fine wares from the Sanders site 2014 surface collection.

\begin{tabular}{|c|c|c|c|c|c|c|c|}
\hline \multirow{2}{*}{$\begin{array}{l}\text { Decorative method } \\
\text { and element }\end{array}$} & \multicolumn{2}{|c|}{ grog } & \multicolumn{2}{|c|}{ bone } & \multicolumn{2}{|c|}{ shell } & \multirow[b]{2}{*}{$\mathrm{N}$} \\
\hline & rim & body & rim & body & rim & body & \\
\hline \multicolumn{8}{|l|}{ Engraved } \\
\hline cross-hatched zone & - & 4 & 1 & - & - & - & 5 \\
\hline cross-hatched lines & - & $3 *$ & - & 1 & - & - & 4 \\
\hline
\end{tabular}


Table 5. Decorative elements in fine wares from the Sanders site 2014 surface collection, cont.

\begin{tabular}{|c|c|c|c|c|c|c|c|}
\hline \multirow{2}{*}{$\begin{array}{l}\text { Decorative method } \\
\text { and element }\end{array}$} & \multicolumn{2}{|c|}{ grog } & \multicolumn{2}{|c|}{ bone } & \multicolumn{2}{|c|}{ shell } & \multirow[b]{2}{*}{$\mathrm{N}$} \\
\hline & rim & body & rim & body & rim & body & \\
\hline curvilinear lines & - & 4 & - & 1 & - & - & 5 \\
\hline $\begin{array}{l}\text { curvilinear lines and } \\
\text { circle el. }\end{array}$ & - & 1 & - & - & - & - & 1 \\
\hline $\begin{array}{l}\text { curvilinear line and } \\
\text { hatched zone }\end{array}$ & - & 1 & - & - & - & - & 1 \\
\hline $\begin{array}{l}\text { curvilinear lines with } \\
\text { tick marks }\end{array}$ & - & 3 & - & - & - & - & 3 \\
\hline $\begin{array}{l}\text { curvilinear lines with } \\
\text { tick marks and cross- } \\
\text { hatched zone }\end{array}$ & - & 1 & - & - & - & - & 1 \\
\hline curvilinear hatched zone & - & 1 & - & - & - & - & 1 \\
\hline $\begin{array}{l}\text { curvilinear cross-hatched } \\
\text { zone }\end{array}$ & - & 1 & - & - & - & - & 1 \\
\hline diagonal lines & - & 1 & - & - & - & - & 1 \\
\hline $\begin{array}{l}\text { diagonal lines and } \\
\text { hatched triangle }\end{array}$ & - & - & - & 1 & - & - & 1 \\
\hline diagonal opposed lines & - & 1 & - & - & - & - & 1 \\
\hline $\begin{array}{l}\text { hatched zone and } \\
\text { negative oval }\end{array}$ & - & 1 & - & - & - & - & 1 \\
\hline horizontal line/lines & 2 & - & 1 & - & 1 & - & 4 \\
\hline $\begin{array}{l}\text { horizontal line and } \\
\text { circle el. }\end{array}$ & 1 & - & - & - & - & - & 1 \\
\hline $\begin{array}{l}\text { horizontal and cross- } \\
\text { hatched bracket }\end{array}$ & 1 & - & - & - & - & - & 1 \\
\hline $\begin{array}{l}\text { horizontal line with } \\
\text { tick marks }\end{array}$ & - & 1 & - & - & - & - & 1 \\
\hline $\begin{array}{l}\text { horizontal lines and } \\
\text { diagonal excised zone }\end{array}$ & 1 & - & - & - & - & - & 1 \\
\hline $\begin{array}{l}\text { horizontal and diagonal } \\
\text { lines }\end{array}$ & 3 & 2 & - & 1 & - & - & 6 \\
\hline $\begin{array}{l}\text { horizontal line and } \\
\text { vertical hatched zone }\end{array}$ & 1 & - & - & - & - & - & 1 \\
\hline opposed lines & - & 6 & - & - & - & - & 6 \\
\hline parallel lines & - & 10 & - & 1 & - & - & 11 \\
\hline straight line & - & $22 *$ & - & 3 & - & 1 & 26 \\
\hline tick marks & - & - & - & - & 1 & - & 1 \\
\hline
\end{tabular}


Table 5. Decorative elements in fine wares from the Sanders site 2014 surface collection, cont.

\begin{tabular}{|c|c|c|c|c|c|c|c|}
\hline \multirow{2}{*}{$\begin{array}{l}\text { Decorative method } \\
\text { and element }\end{array}$} & \multicolumn{2}{|c|}{ grog } & \multicolumn{2}{|c|}{ bone } & \multicolumn{2}{|c|}{ shell } & \multirow[b]{2}{*}{$\mathrm{N}$} \\
\hline & rim & body & rim & body & rim & body & \\
\hline $\begin{array}{l}\text { Engraved-Punctated } \\
\text { horizontal line and row } \\
\text { of excised punctates }\end{array}$ & - & 1 & - & - & - & - & 1 \\
\hline $\begin{array}{l}\text { Red-Slipped } \\
\text { ext. } \\
\text { int. and ext. }\end{array}$ & - & $\begin{array}{r}9 \\
10\end{array}$ & - & - & $\overline{-}$ & $\begin{array}{l}1 \\
1\end{array}$ & $\begin{array}{l}10 \\
15\end{array}$ \\
\hline $\begin{array}{l}\text { Trailed } \\
\text { curvilinear lines }\end{array}$ & - & 1 & - & - & - & - & 1 \\
\hline Totals & 10 & 84 & 2 & 10 & 3 & 3 & 112 \\
\hline
\end{tabular}

*includes one sherd with a red-slipped exterior surface

Sherds with diagonal, diagonal opposed, opposed, diagonal line and hatched triangle, and cross-hatched engraved elements (Figure 13a-c; see Table 5) are from Sanders Engraved carinated bowls and bowls (see Suhm and Jelks 1962:Plate 69). This is the principal fine ware in the ca. A.D. 1100-1300 Sanders phase component at the Sanders site.

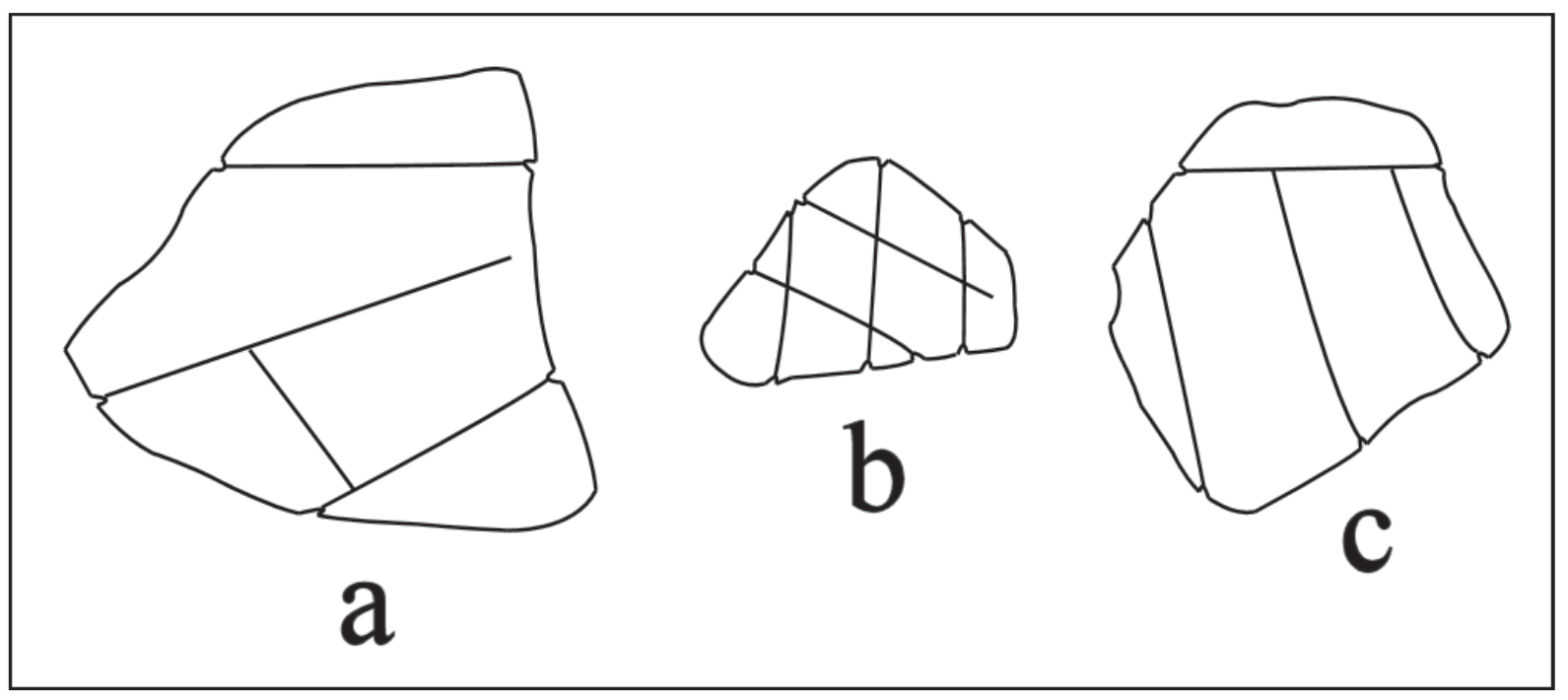

Figure 13. Sanders Engraved body sherds: a, c, Area 9; b, Area 8.

Many of the other engraved sherds in the collection are apparently from Womack Engraved vessels (Figure 14a-1). Womack Engraved was defined by Duffield and Jelks (1961:36-39 and Figures 9 and 10) on the basis of vessels and sherds from sites in the Red and Sabine River basins in East Texas that date from the late 17th century to the mid-18th century. Subsequent archaeological investigations have also identified Womack Engraved vessels and sherds from Late Caddo Titus phase sites in the Little Cypress Creek basin.

Womack Engraved vessels tend to be carinated bowls with inverted rims. There are at least four or five known engraved rim motifs, including: opposed cross-hatched triangles; a negative meandering scroll with 


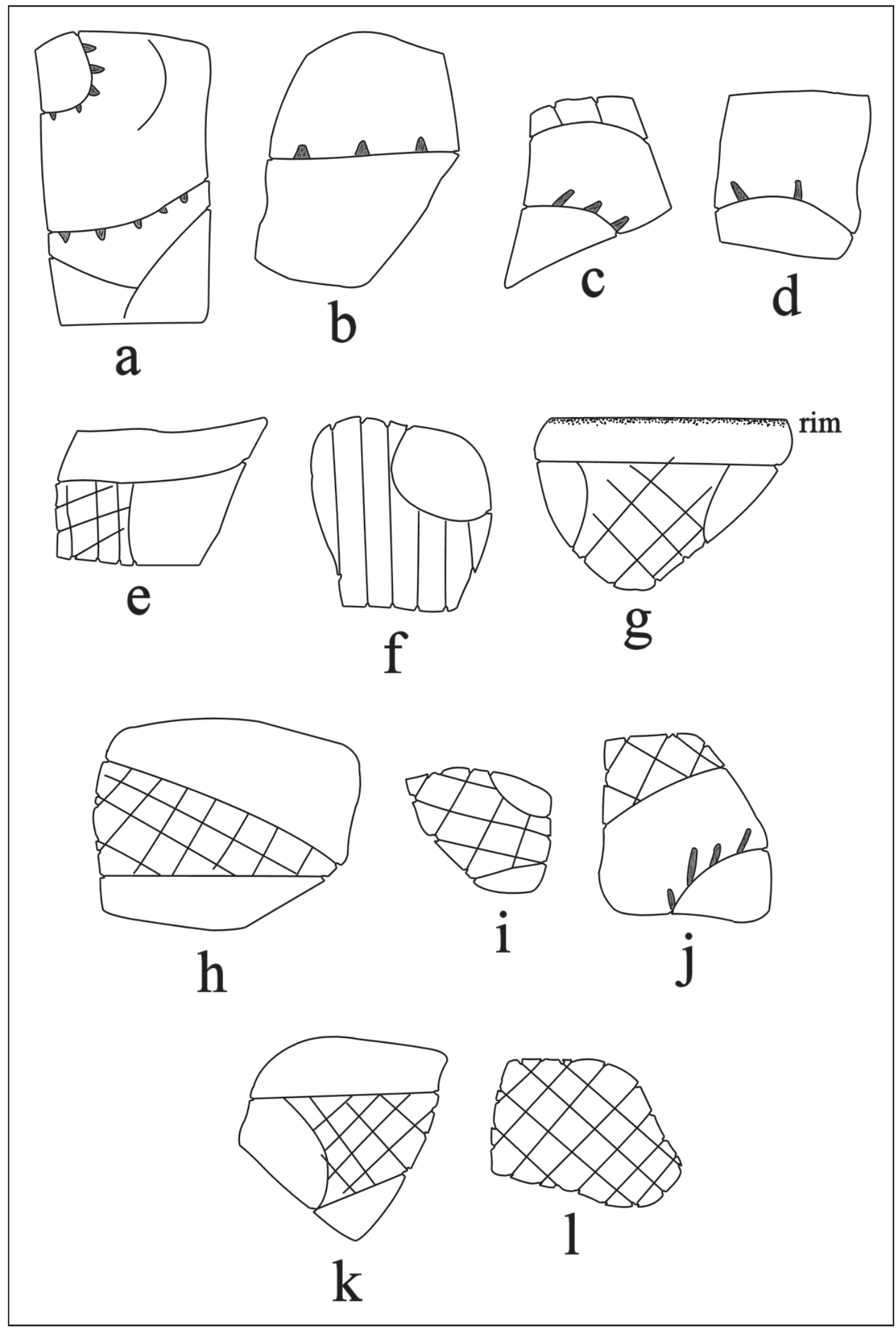

Figure 14. Womack Engraved body sherds: a, Area 11; b-c, Area 6; d, g-j, Area 9; e-f, Area 7; k-1, Area 8. 
a ticked line running along the center of the scroll; parallel and arcing curvilinear lines with or without tick marks; and a negative scroll with ticked lines and cross-hatched pendant triangles running down the center of the scroll (see Story et al. 1967:Figure 49). Several of the sherds from the Sanders site have such identifiable rim motifs.

The grog- and bone-tempered red-slipped sherds $(\mathrm{n}=22)$ are from Sanders Plain bowls and carinated bowls. As redefined by Brown (1996:401-403 and Figures 2-191, 2-34g, 2-37a-1, 2-38d, 2-39d, k, n-q, and $2-42 b)$, Sanders Plain is a grog-tempered, slipped, and undecorated type found widely across the Caddo area, including the middle reaches of the Red River and the upper Sabine River basin. Vessel forms include bowls, carinated bowls, and narrow and wide-mouthed bottles. There are no Maxey Noded Redware vessel sherds in this small assemblage of decorated sherds from the Sanders site, but sherds from this type are wellrepresented in the midden deposits trenched by UT in 1931 between the East and West Mounds (see below) as well as in the burials excavated in the East Mound (Mound No. 1, see Jackson et al. 2000; Krieger 1946).

Half of the shell-tempered fine ware sherds are from vessels decorated only with a red slip (see Table 5). These are from post-A.D. 1300 Clement Redware (cf. Flynn 1976) bowls or carinated bowls. One shelltempered rim has a row of tick marks, a Late to Historic Caddo decorative element, and two shell-tempered rim and body sherds have unidentified horizontal or straight line engraved elements.

Plotting the distribution of temporally diagnostic decorated ceramic sherds across the surface collection areas at the Sanders site suggests that the alluvial terrace landform has had multiple ancestral Caddo occupations in generally the same intra-site sectors. The probable Sanders phase occupation-marked by Sanders Engraved, Sanders Plain, and Canton Incised rim and body sherds - is widely distributed across the landform, from east and southeast of the East Mound (Mound No. 1) to south of the West Mound (Mound No. 2) (Figure 15). The post-A.D. 1300 Caddo occupation-marked by red-slipped and engraved shelltempered sherds, shell-tempered Emory Punctated-Incised, and grog-and bone-tempered Womack Engraved sherds - is less expansive, but also concentrated in clusters east and southeast of the East Mound (Mound No. 1) and south of the West Mound (Mound No. 2) (Figure 16). The predominance of Womack Engraved sherds in the fine wares suggests that this later Caddo occupation probably dates from the late 17th century to the mid-18th century A.D.

\section{Chipped Stone}

The chipped stone tools $(\mathrm{n}=151)$ from the Sanders site are dominated by expedient flake tools (47 percent), scrapers (22.5 percent), and arrow points/arrow point preforms (21.8 percent) (Table 6). The flake tools are most abundant in Areas 5, 7, 9, and 13 in clusters both well south and east-southeast of the two mounds (see Figure 4). Scraping tools are particularly common in Areas 8, 9, and 13, in the same clusters as the flake tools, while arrow points are concentrated in Area 9.

Evidence of the on site manufacture of chipped stone tools from Red River stream gravels at the Sanders site is provided by the recovery of cores and lithic debris from almost every Surface Collection Area (Table 7). Although a comprehensive collection of lithic debris was not obtained during the 2014 surface collection, the highest densities of lithic debris are in Areas 5, 7, 8, 9, and 13 (see Figure 4), east and southeast of the East Mound and south of the West Mound.

\section{Arrow points}

There are 26 arrow points and arrow point fragments as well as seven triangular to ovoid-shaped arrow point preforms in the Sanders site surface collection (Table 8). The triangular arrow points $(n=14)$ have 


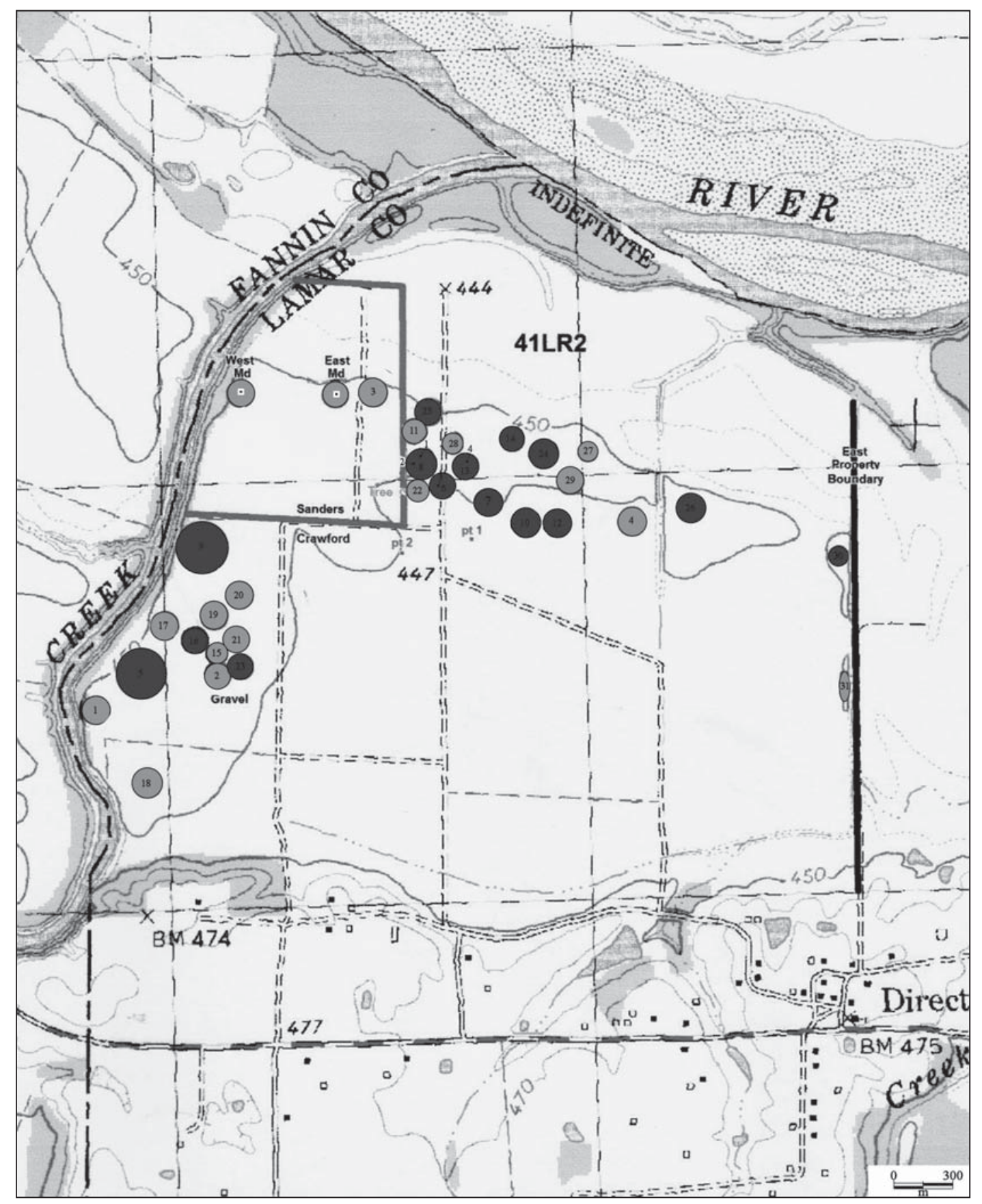

Figure 15. Distribution of decorated sherds with Sanders phase decorative elements.

shallow concave bases (Figure 17a-m), much like Late Caddo style Maud points as well as late 17th-mid18th century Fresno arrow points from Historic Caddo sites in East Texas (Allen et al. 1967:Figure 68f-g). A single cf. Alba/Bonham arrow point made from quartzite in Area 5 at the southern end of the site marks a Sanders phase use (see Jackson et al. 2000:Burial 4 and 5 materials in Mound No. 1).

The triangular arrow points are manufactured from high quality raw materials, including novaculite $(\mathrm{n}=3)$ and Ouachita Mountains cherts $(\mathrm{n}=11)$ (see Table 8). The arrow point fragments and preforms are all made from Ouachita Mountains chert or Red River gravel chert (i.e., brown, yellowish-brown, and reddishbrown colors). 


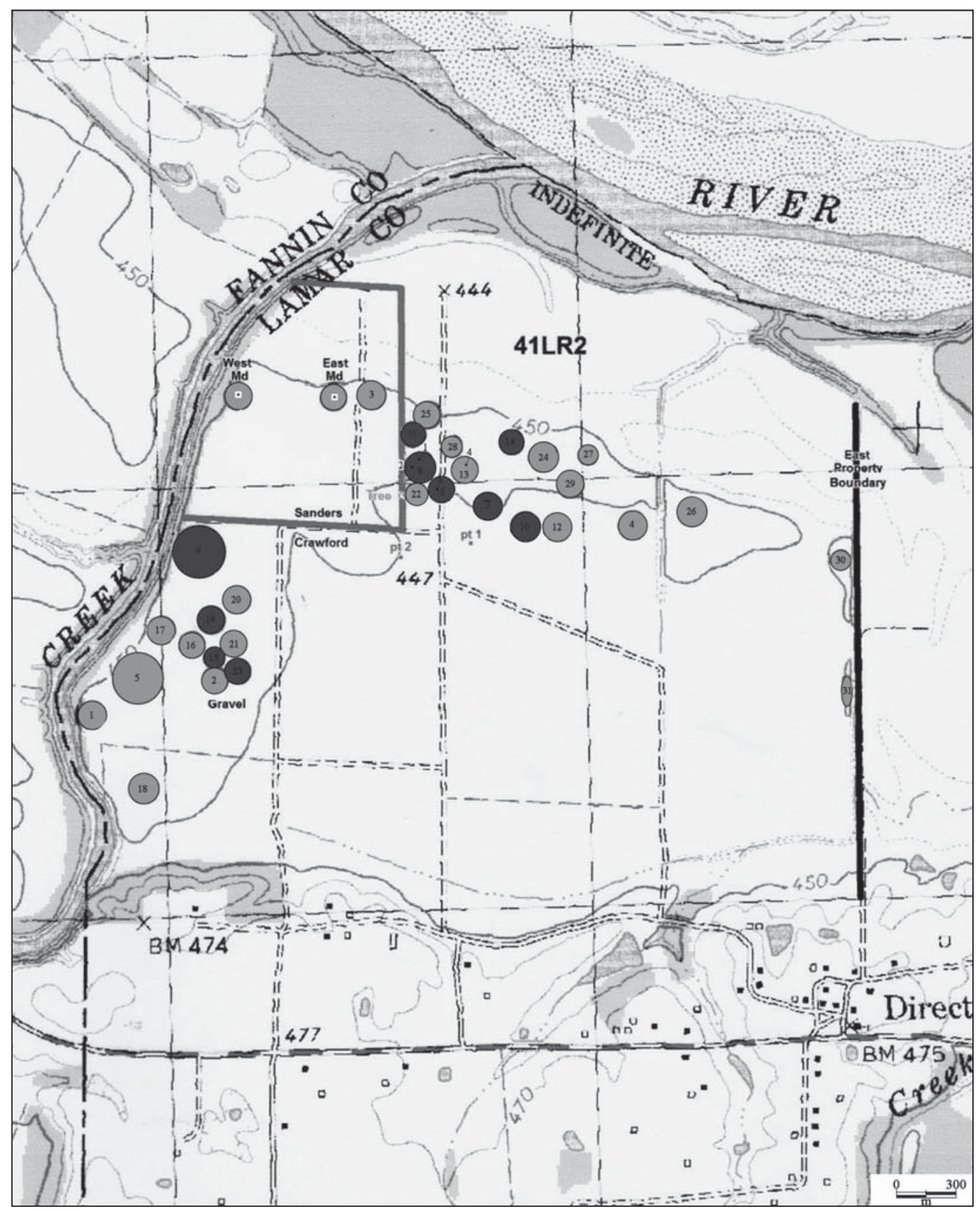

Figure 16. Distribution of decorated sherds with Late to Historic Caddo decorative elements.

These triangular arrow points with concave bases are found in surface collection areas across much of the site (Figure 18). They are clustered ca. 200+ m east and southeast of the East Mound (Mound No. 1), and ca. 300+ m south of the West Mound (Mound No. 2).

\section{Scrapers}

There are 34 unifacial scraping tools in the chipped stone tools from the Sander site (Table 9): end scraper ( $\mathrm{n}=5,14.7$ percent); end scraper with graver tip $(\mathrm{n}=1,2.9$ percent); side scrapers with one working edge $(n=17,50.0$ percent); bilateral side scrapers or side scrapers with two working edges $(n=4,11.8$ percent); a 
Table 6. Chipped Stone Tools from the Sanders site 2014 surface collection.

\begin{tabular}{|c|c|c|c|c|c|c|c|}
\hline Provenience & $\mathrm{AP}$ & APpf & DP & Bif & Scrapers & FT & $\begin{array}{r}\text { Drill/ } \\
\text { Perforator }\end{array}$ \\
\hline Points 1 and 2 & 2 & - & - & - & - & - & - \\
\hline Area 5 & 2 & 1 & - & 2 & 3 & 11 & 1 \\
\hline Area 6 & - & - & - & - & - & 7 & - \\
\hline Area 7 & 1 & 1 & - & - & 2 & 8 & - \\
\hline Area 8 & 1 & 1 & - & - & 5 & 2 & - \\
\hline Area 9 & 10 & 2 & - & 1 & 4 & 8 & 1 \\
\hline Area 10 & - & 1 & - & - & 1 & 4 & - \\
\hline Area 11 & 1 & - & - & - & 2 & 4 & - \\
\hline Area 13 & 3 & - & - & 1 & 8 & 8 & 1 \\
\hline Area 14 & 2 & - & - & - & 1 & 2 & - \\
\hline Area 15 & - & 1 & - & - & - & - & - \\
\hline Area 16 & 1 & - & - & - & 3 & 4 & - \\
\hline Area 17 & - & - & 2 & - & 1 & - & - \\
\hline Area 18 & - & - & - & 1 & - & - & - \\
\hline Area 19 & - & - & 1 & - & 1 & 2 & - \\
\hline Area 20 & - & - & - & - & - & 1 & - \\
\hline Area 21 & - & - & - & 1 & - & 1 & - \\
\hline Area 24 & 2 & - & 1 & - & 1 & 2 & - \\
\hline Area 25 & - & - & - & - & 1 & 1 & - \\
\hline Area 27 & 1 & - & - & - & - & - & - \\
\hline Area 28 & - & - & - & - & 1 & 3 & - \\
\hline Area 29 & - & - & - & - & - & 1 & - \\
\hline Area 30 & - & - & - & - & - & 2 & - \\
\hline Totals & 26 & 7 & 4 & 6 & 34 & 71 & 3 \\
\hline
\end{tabular}

$\mathrm{AP}=$ arrow point $\mathrm{APpf}=$ arrow point preform; $\mathrm{DP}=$ dart point; $\mathrm{Bif}=$ biface; $\mathrm{FT}=$ flake tool

Table 7. Lithic Debris and Cores from 2014 Surface Collection Areas.

\begin{tabular}{lccc}
\hline Provenience & Lithic Debris & Cores & N \\
\hline Area 4 & 4 & - & 4 \\
Area 5 & 68 & - & 68 \\
Area 6 & 22 & - & 22 \\
Area 7 & 54 & - & 54 \\
Area 8 & 73 & - & 73 \\
Area 9 & 34 & - & 34 \\
Area 10 & 30 & - & 31 \\
Area 11 & 17 & - & 17 \\
Area 13 & 39 & - & 39 \\
Area 14 & 14 & 1 & 14 \\
Area 15 & 8 & - & 9 \\
Area 16 & 11 & - & 11 \\
Area 19 & 6 & & 6
\end{tabular}


Table 7. Lithic Debris and Cores from 2014 Surface Collection Areas, cont.

\begin{tabular}{lccr}
\hline Provenience & Lithic Debris & Cores & N \\
\hline Area 21 & 5 & - & 5 \\
Area 22 & 16 & - & 16 \\
Area 23 & 14 & - & 14 \\
Area 24 & 21 & - & 21 \\
Area 25 & 18 & - & 18 \\
Area 26 & 13 & 1 & 14 \\
Area 27 & 3 & - & 4 \\
Area 28 & 8 & 3 & 8 \\
Area 29 & 6 & 1 & 9 \\
Area 30 & 3 & - & 4 \\
Area 31 & 4 & 8 & 4 \\
\hline Totals & 491 & & 499 \\
\hline
\end{tabular}

Table 8. Arrow points from 2014 investigations at the Sanders site.

\begin{tabular}{|c|c|c|c|c|c|c|}
\hline Provenience & Description & Raw Material & $\begin{array}{c}\mathrm{L} \\
(\mathrm{mm})\end{array}$ & $\begin{array}{c}\mathrm{W} \\
(\mathrm{mm})\end{array}$ & $\begin{array}{c}\mathrm{Th} \\
(\mathrm{mm})\end{array}$ & $\begin{array}{l}\mathrm{SW} \\
(\mathrm{mm})\end{array}$ \\
\hline Pt. 1 & triangular & grayish-red novaculite & $10.0+$ & 12.6 & 1.6 & \\
\hline Pt. 2 & triangular & dark grayish-brown chert & $19.0+$ & 12.2 & 2.4 & - \\
\hline Area 5 & preform & grayish-brown chert & $19.0+$ & 22.3 & 3.2 & - \\
\hline Area 5 & triangular & gray novaculite & $13.5+$ & 10.4 & 2.1 & - \\
\hline Area 5 & $\begin{array}{l}\text { cf. Alba/ } \\
\text { Bonham }\end{array}$ & quartzite & 20.4 & 11.4 & - & 5.2 \\
\hline Area 7 & tip & dark gray chert & - & - & 1.6 & - \\
\hline Area 7 & preform & gray chert & 21.2 & 15.2 & 3.1 & - \\
\hline Area 8 & triangular & gray chert & 18.1 & 10.8 & 2.5 & - \\
\hline Area 8 & preform & reddish-brown chert & $16.6+$ & 17.1 & 3.9 & - \\
\hline Area 9 & triangular & grayish-brown chert & 15.7 & 11.6 & 3.1 & - \\
\hline Area 9 & triangular & yellowish-brown chert & 16.8 & 13.4 & 2.3 & - \\
\hline Area 9 & triangular & dark gray chert & 12.3 & 12.1 & 2.9 & - \\
\hline Area 9 & preform & dark gray chert & 25.8 & 15.0 & 4.8 & - \\
\hline Area 9 & preform & gray chert & 24.9 & 15.7 & 4.0 & - \\
\hline Area 9 & blade frag. & dark gray chert & $11.5+$ & 10.1 & 2.4 & - \\
\hline Area 9 & blade frag. & gray chert & $12.3+$ & 12.3 & 2.0 & - \\
\hline Area 9 & blade frag. & dark gray chert & $14.9+$ & 13.7 & 2.7 & - \\
\hline Area 9 & blade frag. & brown chert & $13.9+$ & 12.4 & 2.2 & - \\
\hline Area 9 & blade frag. & black chert & $19.0+$ & 10.0 & 2.8 & - \\
\hline Area 9 & blade frag. & brown chert & $20.7+$ & 10.1 & 2.2 & - \\
\hline Area 9 & blade frag. & brownish-gray chert & $17.4+$ & 12.1 & 2.6 & - \\
\hline
\end{tabular}


Table 8. Arrow points from 2014 investigations at the Sanders site, cont.

\begin{tabular}{|c|c|c|c|c|c|c|}
\hline Provenience & Description & Raw Material & $\begin{array}{c}\mathrm{L} \\
(\mathrm{mm})\end{array}$ & $\begin{array}{c}\mathrm{W} \\
(\mathrm{mm})\end{array}$ & $\begin{array}{c}\mathrm{Th} \\
(\mathrm{mm})\end{array}$ & $\begin{array}{c}\text { SW } \\
(\mathrm{mm})\end{array}$ \\
\hline Area 10 & preform & very dark gray chert & 26.9 & 19.5 & 4.6 & - \\
\hline Area 11 & blade frag. & light gray chert & - & - & 2.3 & - \\
\hline Area 13 & triangular & gray chert & $18.8+$ & 15.0 & 2.2 & - \\
\hline Area 13 & triangular & dark gray chert & $16.1+$ & 13.0 & 2.8 & - \\
\hline Area 13 & triangular & gray chert & 23.6 & 12.3 & 2.6 & - \\
\hline Area 14 & triangular & gray chert & 15.6 & 16.7 & 2.1 & - \\
\hline Area 14 & blade frag. & gray chert & $18.7+$ & 11.5 & 3.1 & - \\
\hline Area 15 & preform & very dark gray chert & $14.2+$ & 14.0 & 3.0 & - \\
\hline Area 16 & triangular & dark gray chert & $15.3+$ & 14.0 & 2.0 & - \\
\hline Area 24 & triangular & very dark grayish-brown chert & 14.0 & 11.9 & 2.5 & \\
\hline Area 24 & tip & very dark grayish-brown chert & - & 17.2 & 2.0 & \\
\hline Area 27 & triangular & gray novaculite & $11.1+$ & 14.5 & 2.0 & - \\
\hline
\end{tabular}

L=length; $\mathrm{W}=$ width; $\mathrm{Th}=$ thickness; $\mathrm{SW}=$ stem width

side scraper with an additional unilateral retouched/used edge opposite the scraping edge ( $\mathrm{n}=1,2.9$ percent); and end-side scrapers $(n=6,17.6$ percent) (Figure 19).

The scrapers are made almost exclusively from high quality Ouachita Mountains cherts (see Table 9). About 5.9 percent of the scrapers, from Areas 7 and 13 in the eastern part of the site, are made from a local quartzite. Utilized edges on the scrapers that are not broken range from $36.9 \mathrm{~mm}$ for end scrapers, 32.9-55.2 $\mathrm{mm}$ for side scrapers, and 75.2-86.9 $\mathrm{mm}$ for end-side scrapers.

Scraping tools are well distributed in surface collection areas across the Sanders site (Figure 20). These are areas east-southeast of the East Mound and well south of the West Mound, the loci for both Sanders phase and Late to Historic Caddo period habitation areas.

\section{Other Chipped Stone Tools}

Other chipped stone tools from the surface collection areas and shovel tests at the Sanders site include 72 flake tools, two drills, one perforator (see Figure 19m), one denticulate, and one unifacial gouge (Table 10). The flake tools, the gouge, and the denticulate are expedient tools used for light-duty cutting, scraping, shredding, and sawing wood, bone, and other organic materials.

The flake tools include those with one working edge ( $n=53$, unilateral); two working edges ( $n=15$, bilateral); three working edges $(n=1$, trilateral); and distal working edges $(n=3)$ (Figure 21). The flake tools are made from various Ouachita Mountains cherts ( 86 percent), novaculite (2.8 percent), a yellow chalcedony 


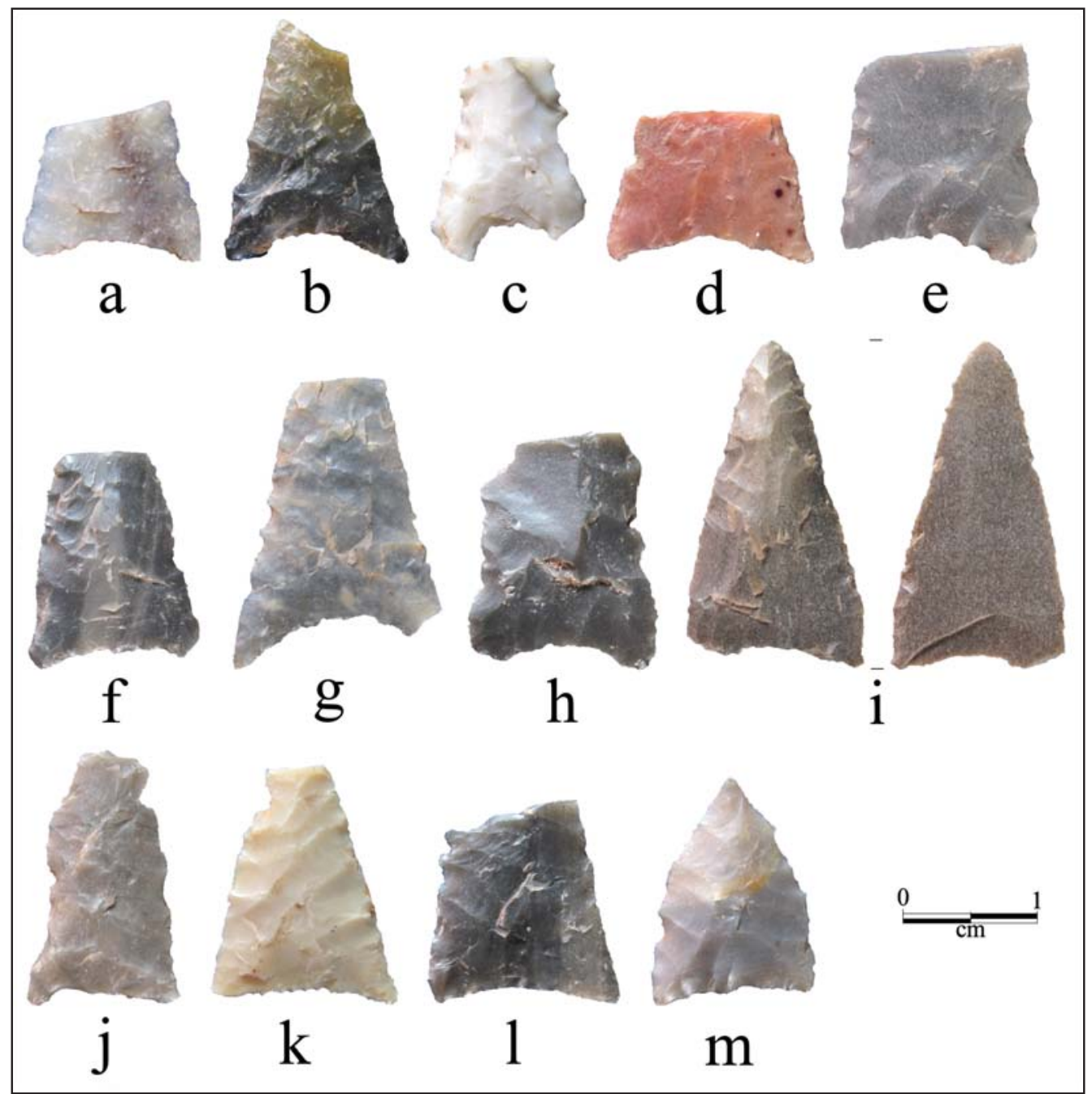

Figure 17. Arrow points from the Sanders site: a, Pt. 1; b, Pt. 2; c, Area 5; d, Area 27; e, Area 16; f, Area 24; g-i, Area 13; j, Area 8; k-m, Area 9.

( $n=1,1.4$ percent), and quartzite $(n=7,9.7$ percent). Most of the latter tools are from Area 9 (see Table 10). The mean working length of the used/retouched edges on the unbroken flake tools is $14.3 \mathrm{~mm}$ for the unilateral tools; $29.1 \mathrm{~mm}$ for the bilateral tools; $49.4 \mathrm{~mm}$ for the trilateral tools; and $17.1 \mathrm{~mm}$ for the distal flake tools (see Table 10).

The surface collection areas with the highest numbers of flake tools are in two different parts of the site (Figure 21). This includes Areas 6, 7, and 13 in the eastern part of the site, and Areas 5 and 9 along Bois d'Arc Creek.

Other flake tools include drills $(n=2)$, a perforator $(n=1)$, a denticulate $(n=1)$, and a unifacial gouge $(n=1)$. The drills and denticulate are on Ouachita Mountains chert, the perforator is made from novaculite, and the gouge is chipped from a local quartzite. They are found in several surface collection areas in the eastern and southern parts of the Sanders site (Figure 22). 


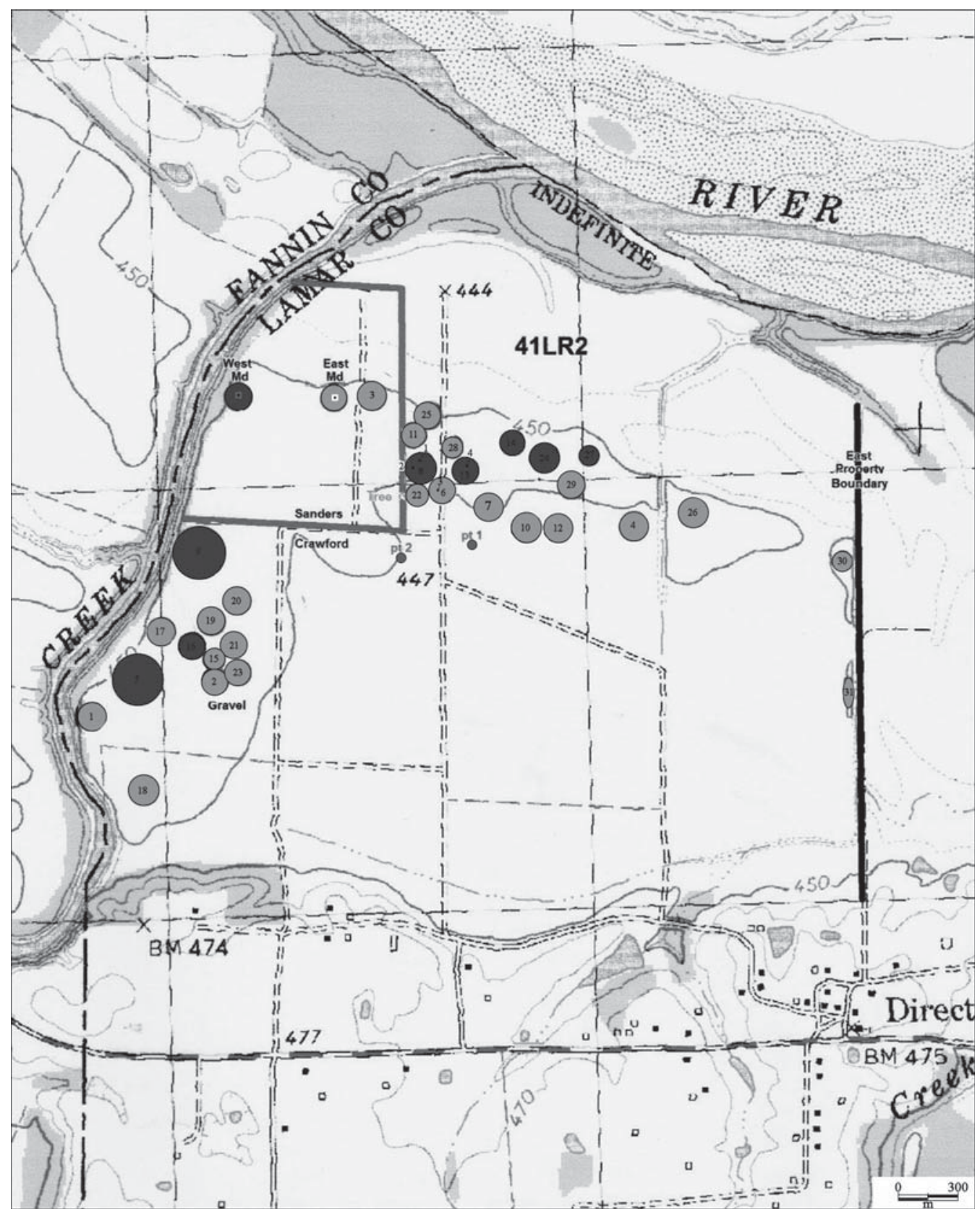

Figure 18. Distribution of triangular arrow points in surface collection areas at the Sanders site.

\section{Dart Points}

A Late Archaic style dart point with a straight stem was found in Area 19 in the southern part of the site (Figures 23 and 24a). It is made from a yellowish-brown chert, and is $49.2 \mathrm{~mm}$ in length, $19.2 \mathrm{~mm}$ in width, $7.6 \mathrm{~mm}$ in thickness, and has a stem width of $11.3 \mathrm{~mm}$. A Kent dart point, a Woodland period form in East Texas, was recovered in Area 24 in the eastern part of the site. The point is made from a very dark grayish-brown chert (22.3+ $\mathrm{mm}$ in length, $25.4 \mathrm{~mm}$ in width, $9.0 \mathrm{~mm}$ thick, and $18.2 \mathrm{~mm}$ stem width). 
Table 9. Scrapers from 2014 archaeological investigations at the Sanders site.

\begin{tabular}{|c|c|c|c|}
\hline Provenience & Description & Raw Material & $\begin{array}{r}\mathrm{UL} \\
(\mathrm{mm})\end{array}$ \\
\hline Area 5 & end & black chert & $20.3+$ \\
\hline Area 5 & end & gray chert & $35.0+$ \\
\hline Area 5 & side & dark gray chert & $20.8+$ \\
\hline Area 7 & end-side & quartzite & 75.2 \\
\hline Area 7 & side & gray chert & $26.5+$ \\
\hline Area 8 & end-side & black chert & 78.4 \\
\hline Area 8 & end-side & black chert & 86.9 \\
\hline Area 8 & side & dark brown chert & 33.7 \\
\hline Area 8 & side & brown chert & 32.9 \\
\hline Area 8 & bilateral side & black chert & $59.0+$ \\
\hline Area 9 & end & gray chert & $35.0+$ \\
\hline Area 9 & end & dark brown chert & $45.0+$ \\
\hline Area 9 & side & black chert & $18.6+$ \\
\hline Area 9 & side & brownish-gray chert & 55.2 \\
\hline Area 10 & end-side & black chert & $33.0+$ \\
\hline Area 11 & side & grayish-brown chert & $29.0+$ \\
\hline Area 11 & side and unilateral FT & brownish-gray chert & $43.0+$ \\
\hline Area 13 & side & very dark gray chert & $18.9+$ \\
\hline Area 13 & side & black chert & $15.8+$ \\
\hline Area 13 & side & quartzite & $26.8+$ \\
\hline Area 13 & side & very dark gray chert & $12.9+$ \\
\hline Area 13 & side & very dark gray chert & $22.1+$ \\
\hline Area 13 & bilateral side & dark gray chert & $43.8+$ \\
\hline Area 13 & bilateral side & white-gray chert & $21.9+$ \\
\hline Area 13 & end-side & black chert & $30.1+$ \\
\hline Area 14 & side & yellowish-brown chert & $10.4+$ \\
\hline Area 16 & side & dark gray chert & $16.9+$ \\
\hline Area 16 & side & gray chert & $15.5+$ \\
\hline Area 16 & bilateral side & dark gray chert & $33.1+$ \\
\hline Area 17 & end & dark gray chert & 36.9 \\
\hline Area 19 & end-side & dark gray chert & $32.0+$ \\
\hline Area 24 & side & brownish-gray chert & $16.9+$ \\
\hline Area 25 & side & grayish-white chert & $25.0+$ \\
\hline Area 28 & end with graver tip & dark gray chert & $14.3+$ \\
\hline
\end{tabular}

$\mathrm{UL}=$ utilized length (in mm); FT=flake tool; +broken 


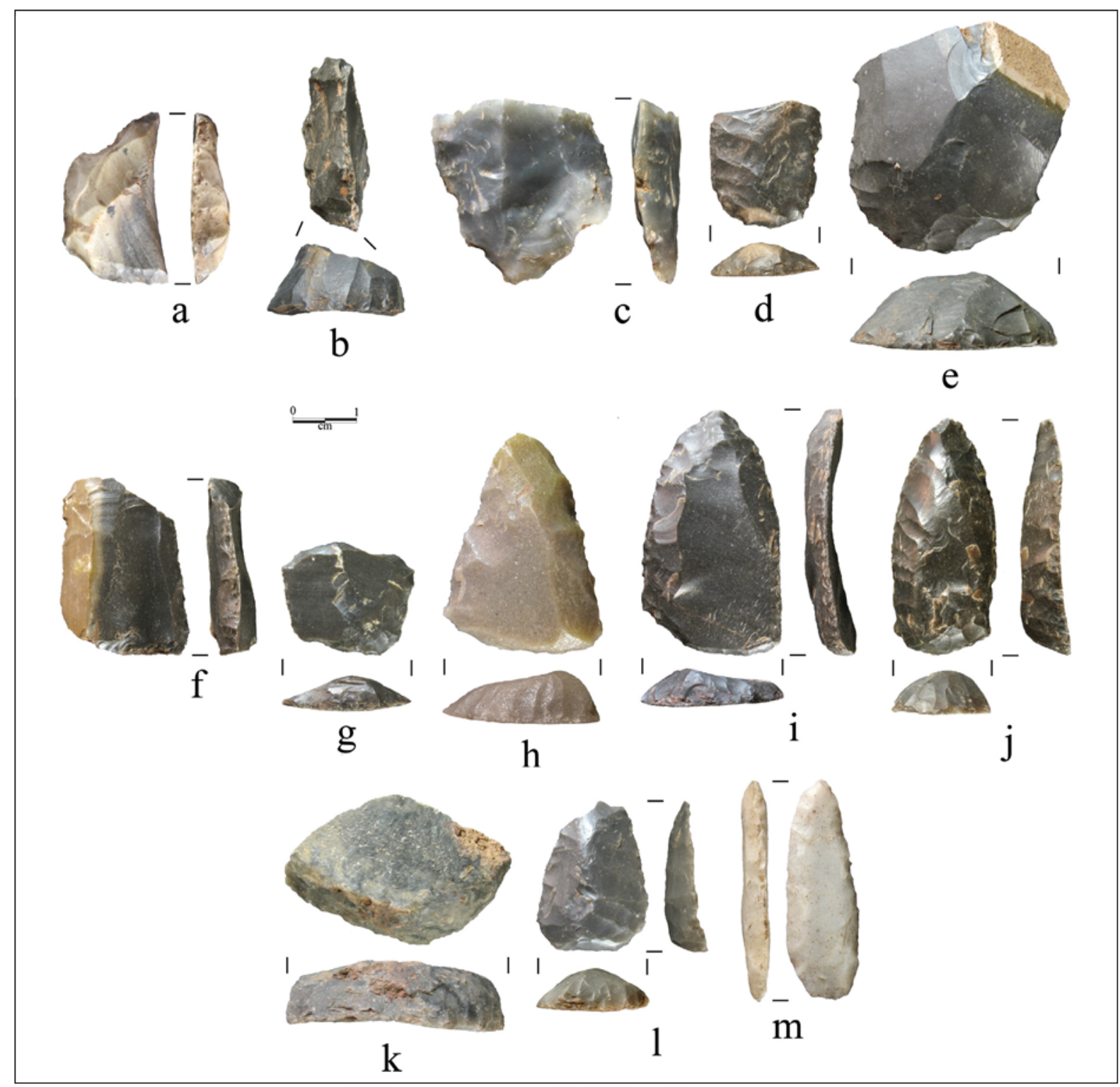

Figure 19. Scraping tools and perforator from surface collection areas at the Sanders site: $a$, Area 19; b, Area 5; c, Area 16; d, Area 10; e, Area 17; f-g, Area 13; h, Area 7; i-j, Area 8; k-m, Area 9.

Two Gary, var. Camden (see Schambach 1998) dart points (dating from ca.A.D. 200-700) were recovered in Area 17 in the southern part of the alluvial terrace (see Figure 24b-c). One is made from a petrified wood, and the other from a reddish-gray quartzite. The points range from 39.4-56.1 mm in length, 18.2-20.9 mm in width, and 5.7-8.1 mm in thickness; stem widths range from 12.1-13.9 mm.

\section{Biface Preforms and Biface Fragments}

There is a single light gray chert biface preform collected from Area 13, and a brown novaculite biface preform fragment in Surface Collection Area 18 at the southern part of the site (see Figure 4). This preform (discarded during dart point manufacture) is $23.2+\mathrm{mm}$ in length, $31.2 \mathrm{~mm}$ in width, and $8.4 \mathrm{~mm}$ in thickness. 


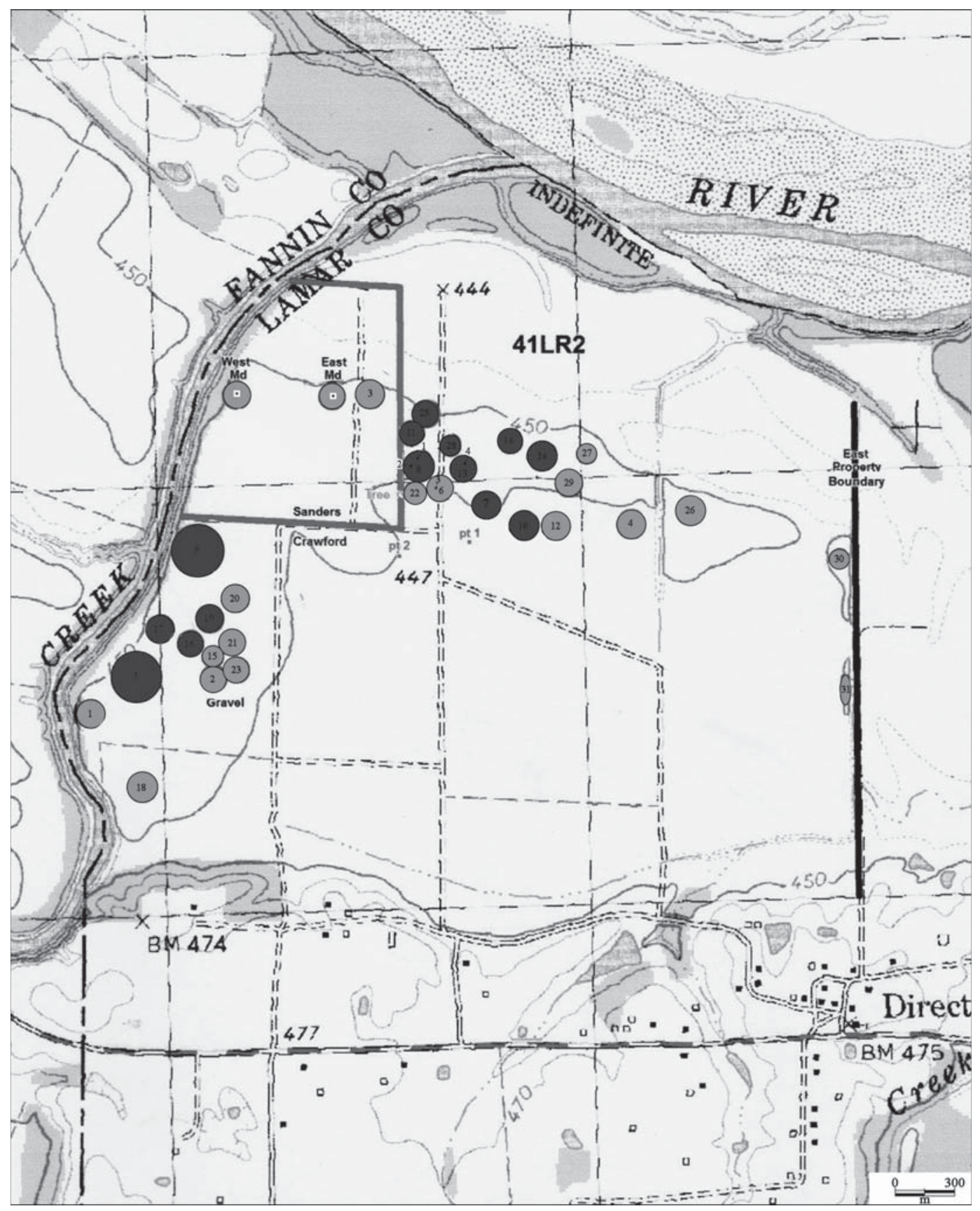

Figure 20. Distribution of scraping tools in surface collection areas at the Sanders site.

The tips to two different bifaces were recovered in Area 5 by Bois d'Arc Creek (see Figure 4). One is made from a light brown chert and the other from a dark grayish-brown chert. Another biface fragment (4.8 mm thick) was found in Area 9. It is made from a brown chert.

\section{Possible Gunflint}

A possible blade gunflint fragment was collected in Surface Collection Area 20 in the southern part of the site. It is manufactured from a black chert and has steep bilateral retouch along one face. The fragment is $18.6+\mathrm{mm}$ in length, $20.2 \mathrm{~mm}$ in width, and $6.7 \mathrm{~mm}$ thick. 
Table 10. Other chipped stone tools from 2014 archaeological investigations at the Sanders site, cont.

\begin{tabular}{|c|c|c|c|c|c|c|}
\hline $\begin{array}{l}\text { Provenience } \\
(\mathrm{cm} \mathrm{bs})\end{array}$ & Description & Raw Material & $\begin{array}{c}\mathrm{L} \\
(\mathrm{mm})\end{array}$ & $\begin{array}{c}\mathrm{W} \\
(\mathrm{mm})\end{array}$ & $\begin{array}{l}\text { Th } \\
(\mathrm{mm})\end{array}$ & $\begin{array}{c}\mathrm{UL} \\
(\mathrm{mm})\end{array}$ \\
\hline ST $4,0-20$ & unilateral FT & dark gray chert & - & - & - & 28.5 \\
\hline ST $4,20-40$ & unilateral FT & novaculite & - & - & - & $11.0+$ \\
\hline ST $4,20-40$ & distal FT & quartzite & - & - & - & 12.0 \\
\hline Area 5 & unilateral FT & grayish-brown chert & - & - & - & 11.7 \\
\hline Area 5 & unilateral FT & grayish-black chert & - & - & - & 12.7 \\
\hline Area 5 & unilateral FT & reddish-brown chert & - & - & - & 12.7 \\
\hline Area 5 & unilateral FT & gray chert & - & - & - & 10.4 \\
\hline Area 5 & unilateral FT & grayish-black chert & - & - & - & 10.6 \\
\hline Area 5 & unilateral FT & dark reddish-brown chert & - & - & - & 5.4 \\
\hline Area 5 & unilateral FT & black chert & - & - & - & $13.0+$ \\
\hline Area 5 & unilateral FT & dark brown chert & - & - & - & 11.5 \\
\hline Area 5 & bilateral FT & dark brown chert & - & - & - & $28.6+$ \\
\hline Area 5 & bilateral FT & dark brown chert & - & - & - & $24.2+$ \\
\hline Area 5 & bilateral FT & brown chert & - & - & - & 18.6 \\
\hline Area 5 & drill & gray chert & 11.2 & 8.6 & - & - \\
\hline Area 6 & unilateral FT & dark gray chert & - & - & - & $7.0+$ \\
\hline Area 6 & unilateral FT & dark grayish-brown chert & - & - & - & 12.0 \\
\hline Area 6 & unilateral FT & black chert & - & - & - & $13.1+$ \\
\hline Area 6 & unilateral FT & dark grayish-brown chert & - & - & - & $7.0+$ \\
\hline Area 6 & unilateral FT & very dark grayish-brown chert & - & - & - & $15.0+$ \\
\hline Area 6 & unilateral FT & black chert & - & - & - & 7.0 \\
\hline Area 6 & bilateral FT & black chert & - & - & - & $26.0+$ \\
\hline Area 7 & bilateral FT & black chert & - & - & - & $24.8+$ \\
\hline Area 7 & bilateral FT & black chert & - & - & - & 57.3 \\
\hline Area 7 & unilateral FT & grayish-brown chert & - & - & - & 17.6 \\
\hline Area 7 & unilateral FT & brown chert & - & - & - & 30.5 \\
\hline Area 7 & unilateral FT & very dark grayish-brown chert & - & - & - & $13.2+$ \\
\hline Area 7 & unilateral FT & black chert & - & - & - & $14.8+$ \\
\hline Area 7 & unilateral FT & light grayish-brown chert & - & - & - & 6.0 \\
\hline Area 7 & distal FT & dark gray chert & - & - & - & 22.1 \\
\hline Area 8 & unilateral FT & black chert & - & - & - & 20.2 \\
\hline Area 8 & denticulate & black chert & - & - & - & 21.9 \\
\hline Area 9 & unilateral FT & quartzite & - & - & - & 17.5 \\
\hline Area 9 & unilateral FT & quartzite & - & - & - & 6.7 \\
\hline Area 9 & unilateral FT & black chert & - & - & - & $20.3+$ \\
\hline Area 9 & unilateral FT & gray chert & - & - & - & $22.4+$ \\
\hline Area 9 & bilateral FT & quartzite & - & - & - & $28.4+$ \\
\hline Area 9 & bilateral FT & quartzite & - & - & - & $28.1+$ \\
\hline Area 9 & bilateral FT & gray chert & - & - & - & 28.3 \\
\hline Area 9 & trilateral FT & gray chert & - & - & - & 49.4 \\
\hline
\end{tabular}


Table 10. Other chipped stone tools from 2014 archaeological investigations at the Sanders site, cont.

\begin{tabular}{|c|c|c|c|c|c|c|}
\hline $\begin{array}{l}\text { Provenience } \\
\text { (cm bs) }\end{array}$ & Description & Raw Material & $\begin{array}{c}\mathrm{L} \\
(\mathrm{mm})\end{array}$ & $\begin{array}{c}\mathrm{W} \\
(\mathrm{mm})\end{array}$ & $\begin{array}{l}\text { Th } \\
(\mathrm{mm})\end{array}$ & $\begin{array}{c}\mathrm{UL} \\
(\mathrm{mm})\end{array}$ \\
\hline Area 9 & perforator & white novaculite & 32.4 & 10.6 & 4.1 & - \\
\hline Area 10 & unilateral FT & black chert & - & - & - & 9.0 \\
\hline Area 10 & unilateral FT & black chert & - & - & - & $15.2+$ \\
\hline Area 10 & unilateral FT & very dark grayish-brown chert & - & - & - & 12.5 \\
\hline Area 10 & unilateral FT & gray-dark gray chert & - & - & - & 15.9 \\
\hline Area 11 & unilateral FT & gray chert & - & - & - & $8.0+$ \\
\hline Area 11 & unilateral FT & black chert & - & - & - & $12.9+$ \\
\hline Area 11 & bilateral FT & black chert & - & - & - & $42.5+$ \\
\hline Area 11 & bilateral FT & dark gray chert & - & - & - & $23.7+$ \\
\hline Area 13 & drill frag. & brown-dark gray chert & & & & \\
\hline Area 13 & unilateral FT & black chert & - & - & - & $38.9+$ \\
\hline Area 13 & unilateral FT & dark grayish-brown chert & - & - & - & $7.0+$ \\
\hline Area 13 & unilateral FT & light gray chert & - & - & - & $14.0+$ \\
\hline Area 13 & unilateral FT & dark brown chert & - & - & - & $9.0+$ \\
\hline Area 13 & unilateral FT & dark gray chert & - & - & - & 9.1 \\
\hline Area 13 & unilateral FT & dark gray chert & - & - & - & $11.9+$ \\
\hline Area 13 & unilateral FT & gray chert & - & - & - & $11.9+$ \\
\hline Area 13 & distal FT & dark gray chert & - & - & - & $7.1+$ \\
\hline Area 14 & bilateral FT & black chert & - & - & - & 24.0 \\
\hline Area 14 & unilateral FT & dark grayish-brown chert & - & - & - & 9.4 \\
\hline Area 16 & unilateral FT & white chert & - & - & - & $7.0+$ \\
\hline Area 16 & unilateral FT & very dark grayish-brown chert & - & - & - & 27.0 \\
\hline Area 16 & unilateral FT & quartzite & - & - & - & $6.0+$ \\
\hline Area 16 & unilateral FT & yellow chalcedony & - & - & - & $24.5+$ \\
\hline Area 19 & unilateral FT & black chert & - & - & - & $13.7+$ \\
\hline Area 19 & unilateral FT & dark gray chert & - & - & - & $11.0+$ \\
\hline Area 20 & unilateral FT & dark gray chert & - & - & - & $13.2+$ \\
\hline Area 21 & unilateral FT & white novaculite & - & - & - & $12.9+$ \\
\hline Area 24 & unilateral FT & gray chert & - & - & - & $17.3+$ \\
\hline Area 24 & bilateral FT & gray chert & - & - & - & 26.0 \\
\hline Area 25 & bilateral FT & brownish-gray chert & - & - & - & $18.5+$ \\
\hline Area 28 & unilateral FT & grayish-brown chert & - & - & - & 19.8 \\
\hline Area 28 & unilateral FT & gray chert & - & - & - & 18.1 \\
\hline Area 28 & unifacial & quartzite gouge & - & - & - & - \\
\hline
\end{tabular}


Table 10. Other chipped stone tools from 2014 archaeological investigations at the Sanders site, cont.

\begin{tabular}{|c|c|c|c|c|c|c|}
\hline $\begin{array}{l}\text { Provenience } \\
(\mathrm{cm} \text { bs) }\end{array}$ & Description & Raw Material & $\begin{array}{c}\mathrm{L} \\
(\mathrm{mm})\end{array}$ & $\begin{array}{c}\mathrm{W} \\
(\mathrm{mm})\end{array}$ & $\begin{array}{c}\text { Th } \\
(\mathrm{mm})\end{array}$ & $\begin{array}{c}\mathrm{UL} \\
(\mathrm{mm})\end{array}$ \\
\hline Area 29 & bilateral FT & very dark grayish-brown chert & - & - & - & 21.0 \\
\hline Area 30 & unilateral FT & grayish-brown chert & - & - & - & 15.3 \\
\hline Area 30 & unilateral FT & quartzite & - & - & - & $16.9+$ \\
\hline
\end{tabular}

FT=flake tool; $\mathrm{L}=$ length; $\mathrm{W}=$ width; $\mathrm{Th}=$ thickness; $\mathrm{UL}=$ use wear length

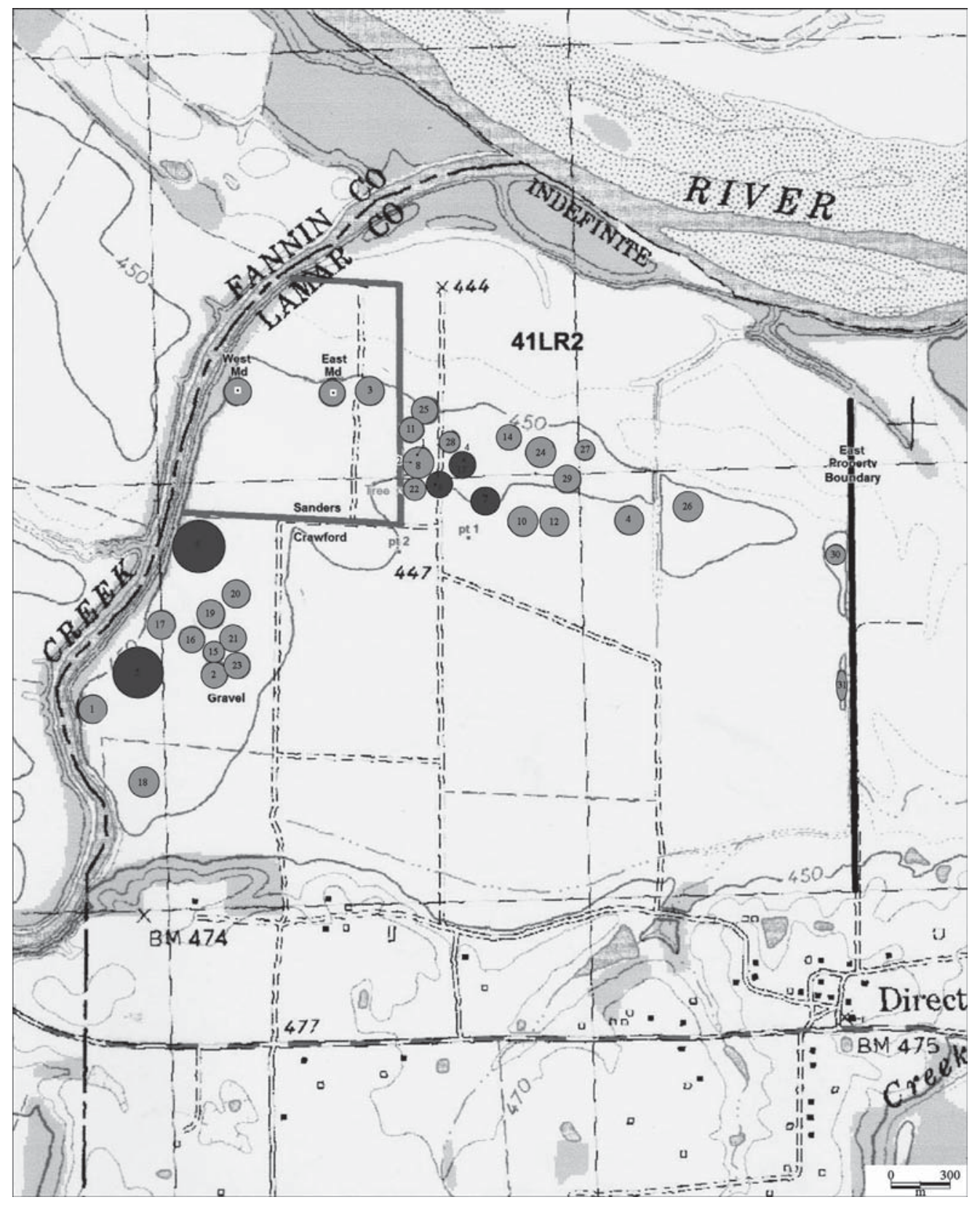

Figure 21. Highest number of flake tools from the surface collection areas at the Sanders site. 


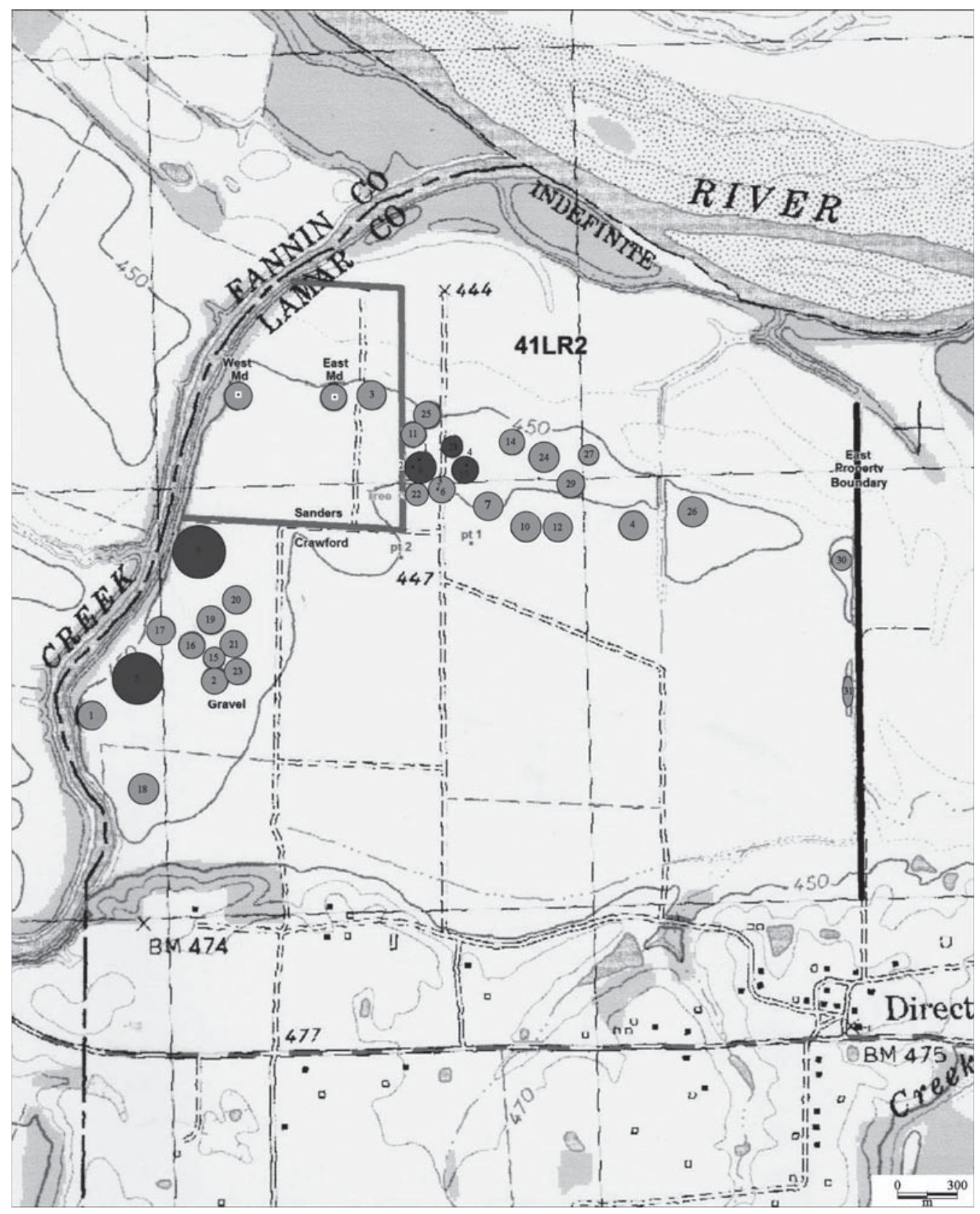

Figure 22. Distribution of drills, perforator, denticulate, and gouge in the surface collection areas at the Sanders site.

\section{Ground Stone}

A small siliceous shale (a Ouachita Mountains raw material, probably available in Red River gravels downstream from the Sanders site) celt was recovered in Area 5 in the southern part of the site. The bifacially worked celt is $56.6 \mathrm{~mm}$ in length, $38.0 \mathrm{~mm}$ in width, and $14.5 \mathrm{~mm}$ in thickness. One ground stone tool was collected in Area 29. It is a sandstone mano and 1-sided pitted stone $69 \mathrm{~mm}$ in length, $55 \mathrm{~mm}$ in width, and $38 \mathrm{~mm}$ in thickness. 


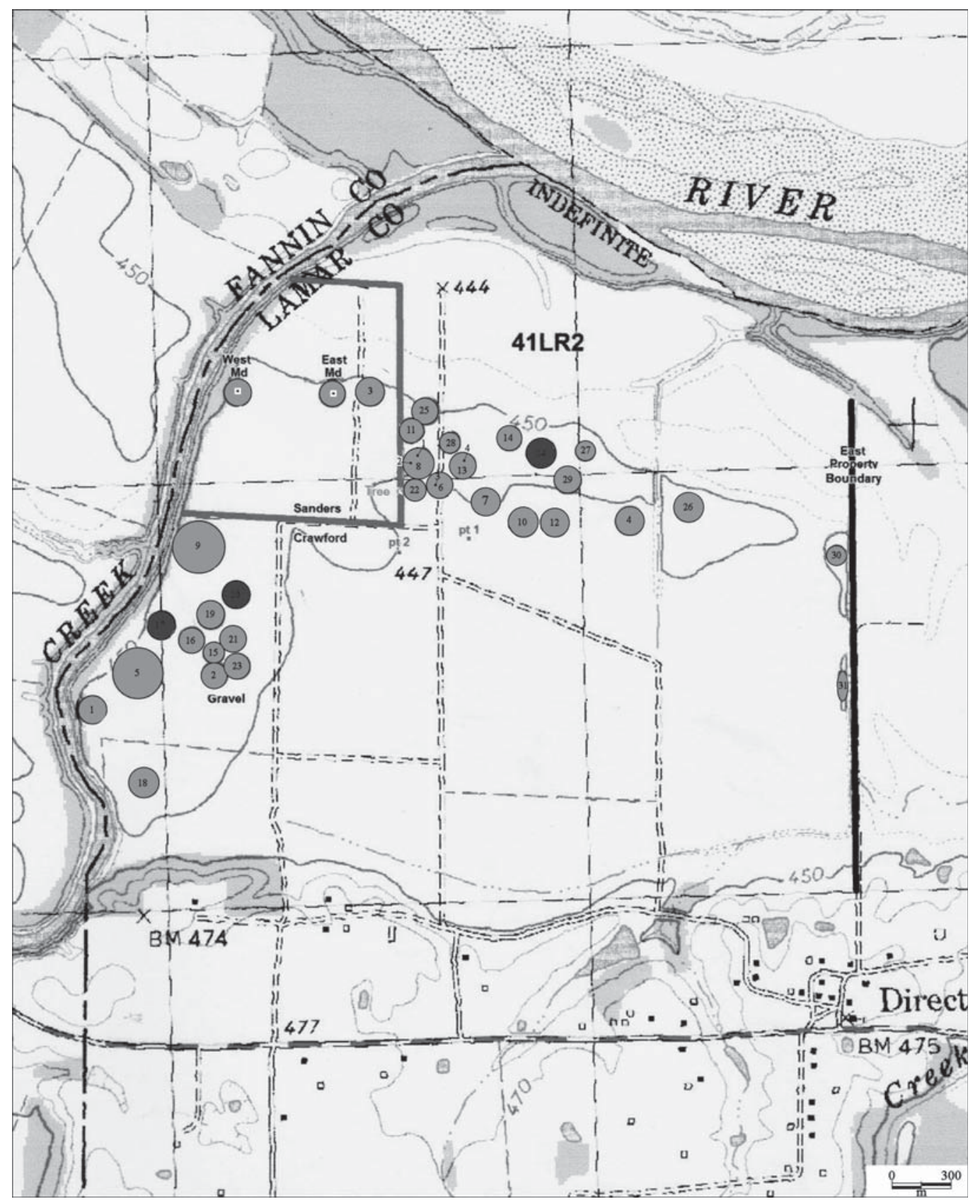

Figure 23. Distribution of dart points in surface collection areas at the Sanders site.

\section{Fire-cracked Rock}

The one piece of fire-cracked rock was collected from Area 30 at the far eastern end of the Sanders site. The piece was a local quartzite.

\section{Animal Bones}

In addition to several pieces of animal bone recovered in the shovel tests (see Table 1), burned animal bones were collected from Surface Collection Area $7(n=1)$, Area $9(n=1)$, Area $13(n=1)$, Area $14(n=1)$, and 


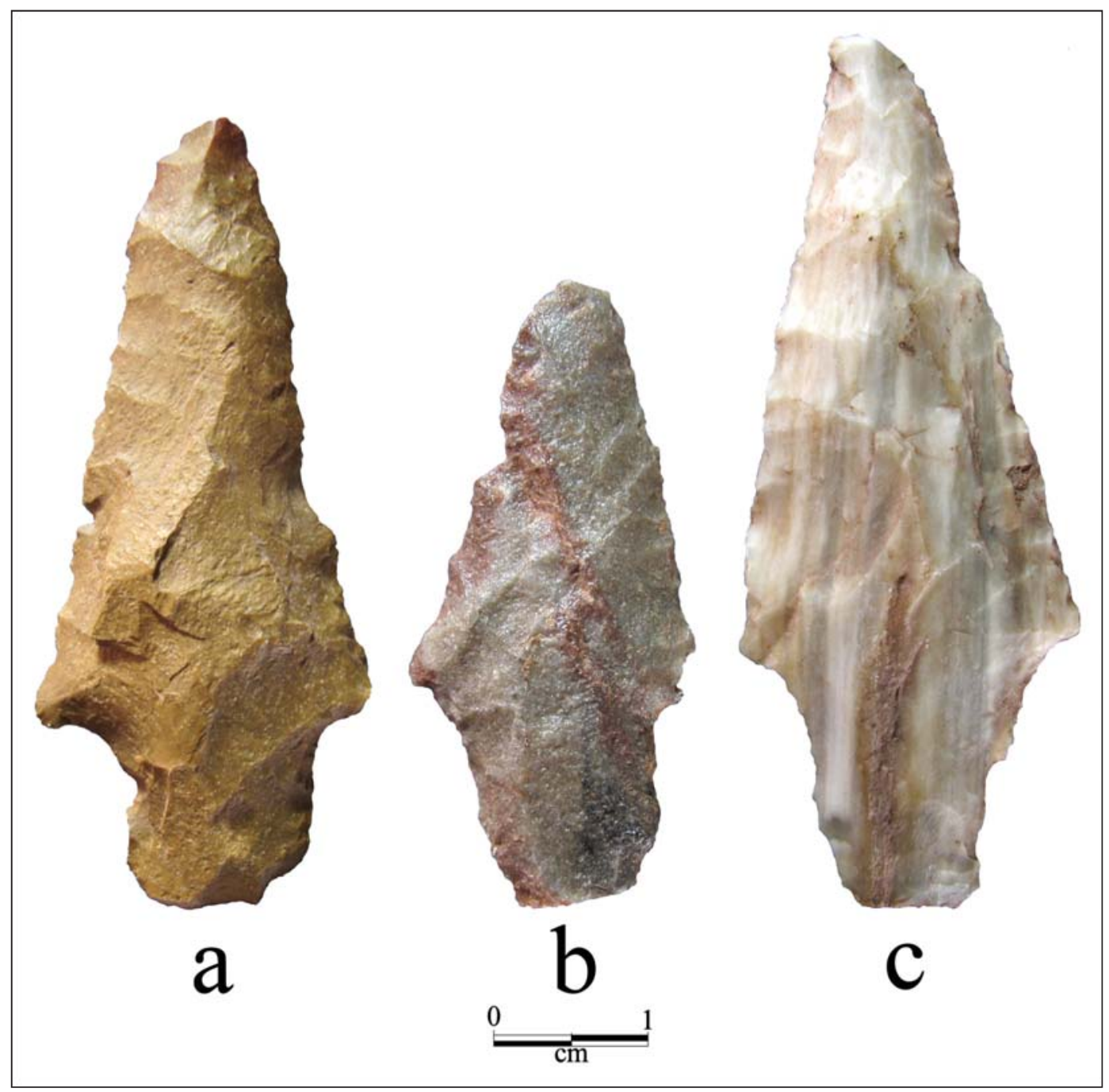

Figure 24. Dart points from the Sanders site: a, Area 19; b-c, Area 17.

Area $24(n=1)$. Unburned animal bone was collected from Area $8(n=6)$ and Area $23(n=1)$. Most of these finds are from surface artifact clusters east and southeast of the East Mound (Mound No. 1) (see Figure 4).

\section{Ceramic Sherds and Chipped Stone Tools from the Sanders Site in TARL Collections}

There are a number of artifact collections from non-mound contexts at the Sanders site held by TARL. The principal collection is the assemblage recovered in 1931 trenching by UT (Jackson et al. 2000; Krieger 1946) in midden deposits on an alluvial ridge between Mounds No. 1 (East Mound) and No. 2 (West Mound). The largest midden deposit was ca. $5.6 \times 10 \mathrm{~m}$ in size, and extended to ca. $1.4 \mathrm{~m}$ bs (Pearce and Jackson 1931). TARL also holds collections by T. R. Baker, R. K. Harris (10 glass beads from the historic part of the site), Maude Neville (a turkey bone bead); W. A. Rikard, O. L. Crook, J. R. Sollberger, the National Park Service (Carl Steen), and Gary Sykes; this last collection of materials was apparently collected in the 1930s by J. R. Sollberger and Erwin Rubland from just north of Mound No. 2, and donated by Sykes to TARL in 1984. These collections are discussed together in this section. 


\section{Ceramic Sherds}

The ceramic sherd collection from the Sanders site that were examined for this study includes 693 decorated sherds and 85 plain sherds, the latter primarily from an area north of Mound No. 2 (West Mound) (Table 11). About 77 percent of the sherds are from grog-tempered vessels, 17.1 percent are from bonetempered vessels, and 5.9 percent are from shell-tempered vessels. These proportions are not significantly different from the decorated sherd assemblage in the 2014 surface collection areas, where 81 percent of the sherds are grog-tempered, 13 percent are bone-tempered, and 6 percent are shell-tempered (see Table 3).

Table 11. Ceramic Sherds from TARL Collections at the Sanders site.

\begin{tabular}{|c|c|c|c|c|c|c|c|}
\hline \multirow[b]{2}{*}{ Decorative method } & \multicolumn{2}{|c|}{ Grog } & \multicolumn{2}{|c|}{ Bone } & \multicolumn{2}{|c|}{ Shell } & \multirow[b]{2}{*}{$\mathrm{N}$} \\
\hline & rim & body & rim & body & $\operatorname{rim}$ & body & \\
\hline \multicolumn{8}{|l|}{ Utility Ware } \\
\hline Appliqued & - & 4 & - & - & - & 1 & 5 \\
\hline Appliqued-Incised & 1 & - & - & - & - & - & 1 \\
\hline Brushed & - & 2 & - & - & - & - & 2 \\
\hline Brushed-Incised & - & 1 & - & - & - & - & 1 \\
\hline Corn Cob Impressed & - & 1 & - & - & - & - & 1 \\
\hline Incised & 67 & 115 & 18 & 25 & 1 & 4 & 230 \\
\hline Incised-Punctated & 6 & 15 & 2 & 3 & - & - & 26 \\
\hline Lip Notched & 5 & - & 1 & - & - & - & 6 \\
\hline Neck Banded & - & 1 & - & - & 2 & - & 3 \\
\hline Pinched & - & 3 & - & 1 & - & - & 4 \\
\hline Punctated & 8 & 29 & 2 & 3 & - & 5 & 47 \\
\hline Subtotal & 87 & 171 & 23 & 32 & 3 & 10 & 326 \\
\hline Percent & 26.7 & 52.5 & 7.1 & 9.8 & 0.9 & 3.1 & \\
\hline \multicolumn{8}{|l|}{ Fine Ware } \\
\hline Engraved & 83 & 85 & 18 & 13 & 6 & 12 & 217 \\
\hline Red-Slipped & 16 & 86 & 2 & 33 & - & 8 & 145 \\
\hline Red-Slipped-Appliqued & - & 1 & - & - & - & - & 1 \\
\hline Red Slipped-Punctated & - & 3 & - & 1 & - & - & 4 \\
\hline Subtotal & 99 & 175 & 20 & 47 & 6 & 20 & 367 \\
\hline Percent & 27.0 & 47.7 & 5.5 & 12.8 & 1.6 & 5.5 & \\
\hline Plain Ware & $21^{*}$ & 45 & 1 & 11 & 2 & 5 & 85 \\
\hline Totals & 207 & 391 & 44 & 90 & 11 & 35 & 778 \\
\hline Percent & 26.6 & 50.3 & 5.6 & 11.5 & 1.4 & 4.5 & \\
\hline
\end{tabular}

*one rim sherd has a small attached lip tab 


\section{Utility Wares}

Two of the grog-tempered appliqued body sherds have a single appliqued node, while a third body sherd has broad curvilinear appliqued ridges. Another grog-tempered body sherd has parallel appliqued fillets. The one shell-tempered appliqued body sherd has a straight (probably vertical in orientation on the vessel body) appliqued ridge. One incised-appliqued rim sherd has diagonal opposed incised lines divided by a near-vertical appliqued fillet.

There is a grog-tempered body sherd from a vessel with overlapping brushing marks, and a second one with parallel brushing marks. The one brushed-incised body sherd is from a grog-tempered jar. The lower part of the vessel has parallel vertical sets of incised lines and a vertical hatched incised ladder that end at a single horizontal incised line at the rim-body juncture. Diagonal brushing marks underlie the sets of vertical incised lines.

One grog-tempered body sherd has possible corn cob impressions on its exterior surface. It appears that a corn cob was impressed on the wet surface of a utility ware jar before it was fired. Corn cob impressed sherds from utility ware jars have been identified in post-A.D. 1430 Caddo sites (Titus phase) in the upper Sabine River basin in East Texas, and these jars may be related to the one corn cob impressed sherd in the Sanders site collection.

About 98 percent of the incised sherds are from vessels tempered with grog or bone; only 2 percent are from shell-tempered vessels (Table 12). The shell-tempered sherds may be from certain Emory PunctatedIncised vessels that have simple incised decorative elements on their bodies, but the one shell-tempered cross-hatched incised rim sherd is from a vessel of unknown type.

Table 12. Decorative elements on incised rim and body sherds.

\begin{tabular}{|c|c|c|c|c|c|c|c|}
\hline \multirow[b]{2}{*}{ Decorative element } & \multicolumn{2}{|c|}{ grog } & \multicolumn{2}{|c|}{ bone } & \multicolumn{2}{|c|}{ shell } & \multirow[b]{2}{*}{$\mathrm{N}$} \\
\hline & rim & body & rim & body & rim & body & \\
\hline cross-hatched lines & 12 & 13 & 4 & 5 & 1 & - & 35 \\
\hline $\begin{array}{l}\text { cross-hatched and horizontal } \\
\text { line }\end{array}$ & 2 & 1 & - & - & - & - & 3 \\
\hline diagonal lines & - & 2 & - & 1 & - & - & 3 \\
\hline diagonal lines, pitched $\mathrm{R}$ to $\mathrm{L}$ & 16 & 4 & 4 & - & - & - & 24 \\
\hline diagonal lines, pitched $\mathrm{L}$ to $\mathrm{R}$ & 12 & - & - & - & - & - & 12 \\
\hline $\begin{array}{l}\text { diagonal panel filled with cross- } \\
\text { hatched lines }\end{array}$ & 1 & - & - & - & - & - & 1 \\
\hline $\begin{array}{l}\text { diagonal panels filled with } \\
\text { diagonal lines }\end{array}$ & 1 & - & 1 & - & - & - & 2 \\
\hline diagonal opposed lines & $16^{*}$ & 33 & 7 & 10 & - & - & 66 \\
\hline hatched triangle & 1 & 1 & - & - & - & - & 2 \\
\hline horizontal lines & 3 & 2 & - & - & - & - & 5 \\
\hline horizontal and diagonal lines & - & 1 & 1 & 1 & - & - & 3 \\
\hline $\begin{array}{l}\text { horizontal and diagonal } \\
\text { opposed lines }\end{array}$ & 1 & - & - & - & - & - & 1 \\
\hline $\begin{array}{l}\text { horizontal and diagonal } \\
\text { opposed lines and hatched oval }\end{array}$ & - & 1 & - & - & - & - & 1 \\
\hline
\end{tabular}


Table 12. Decorative elements on incised rim and body sherds, cont.

\begin{tabular}{|c|c|c|c|c|c|c|c|}
\hline \multirow[b]{2}{*}{ Decorative element } & \multicolumn{2}{|c|}{ grog } & \multicolumn{2}{|c|}{ bone } & \multicolumn{2}{|c|}{ shell } & \multirow[t]{2}{*}{$\mathrm{N}$} \\
\hline & rim & body & rim & body & rim & body & \\
\hline opposed lines & - & - & - & - & - & 1 & 1 \\
\hline opposed incised open triangle & - & - & 1 & - & - & - & 1 \\
\hline parallel lines & - & 46 & - & 8 & - & 3 & 57 \\
\hline straight line & - & 1 & - & - & - & - & 1 \\
\hline vertical lines & 2 & - & 1 & - & - & - & 3 \\
\hline $\begin{array}{l}\text { vertical line and diagonal } \\
\text { opposed panels }\end{array}$ & - & 1 & - & - & - & - & 1 \\
\hline $\begin{array}{l}\text { vertical panels filled with } \\
\text { diagonal lines }\end{array}$ & - & 8 & 1 & - & - & - & 9 \\
\hline Totals & 67 & 114 & 20 & 25 & 1 & 4 & 231 \\
\hline
\end{tabular}

*includes one sherd with incised decoration on vessel interior surface; R=right; $\mathrm{L}=$ left

The majority of the grog- and bone-tempered incised sherds may be from Canton Incised vessels, especially those rim sherds with cross-hatched (Figure 25a), diagonal, and diagonal opposed (Figure 25b, d, f) decorative elements (see Table 12 and Suhm and Jelks 1962:Plate 12). These three decorative elements comprise 74 percent of the incised rims in the TARL collections from the Sanders site.

Secondary incised decorative elements include rim and body sherds with vertical incised lines and panels $(n=13,5.6$ percent of the incised sherds, see Table 12), rims with sets of horizontal lines ( $n=5,2.2$ percent), and sets of horizontal lines with associated diagonal or diagonal opposed lines ( $n=5,2.2$ percent); these latter may be from Dunkin Incised vessels. Much less common incised decorative elements in the Sanders site ceramic assemblage include diagonal panels filled with diagonal incised lines (see Figure 25c), diagonal incised panels filled with cross-hatched lines (see Figure 25e), and hatched triangles below the vessel lip (see Figure 25g).

In addition to the incised rim and body sherds, there is a partial grog-tempered vessel section with an incised decorative element. These are rim sherds from a Canton Incised jar with cross-hatched incised lines on the rim.

The sherds with incised-punctated decorative elements are only from vessels tempered with grog (82 percent) or bone (18 percent) (Table 13). In most cases, these sherds also appear to be from Canton Incised vessels with repeated triangular incised zones (from sets of diagonal opposed lines) filled with tool, cane, circular, and fingernail punctates (Figure 26a, e, g). About 71 percent of the incised-punctated sherds in the TARL collection are from such Canton Incised vessels.

Other probable Canton Incised vessel sherds from the site include a rim with cross-hatched lines above four rows of fingernail impressions (see Figure 26b), another rim with intersecting diagonal and horizontal lines above a single row of punctations at the rim-body juncture (see Figure 26d), and a third rim with punctated-filled incised triangles pendant from a horizontal incised line (see Figure 26f; see also Suhm and Jelks 1962:Plate 12i). A distinctive lower rim/body sherd from a utility ware vessel of unknown type has vertical incised panels filled with tool punctates (see Figure 26c). 


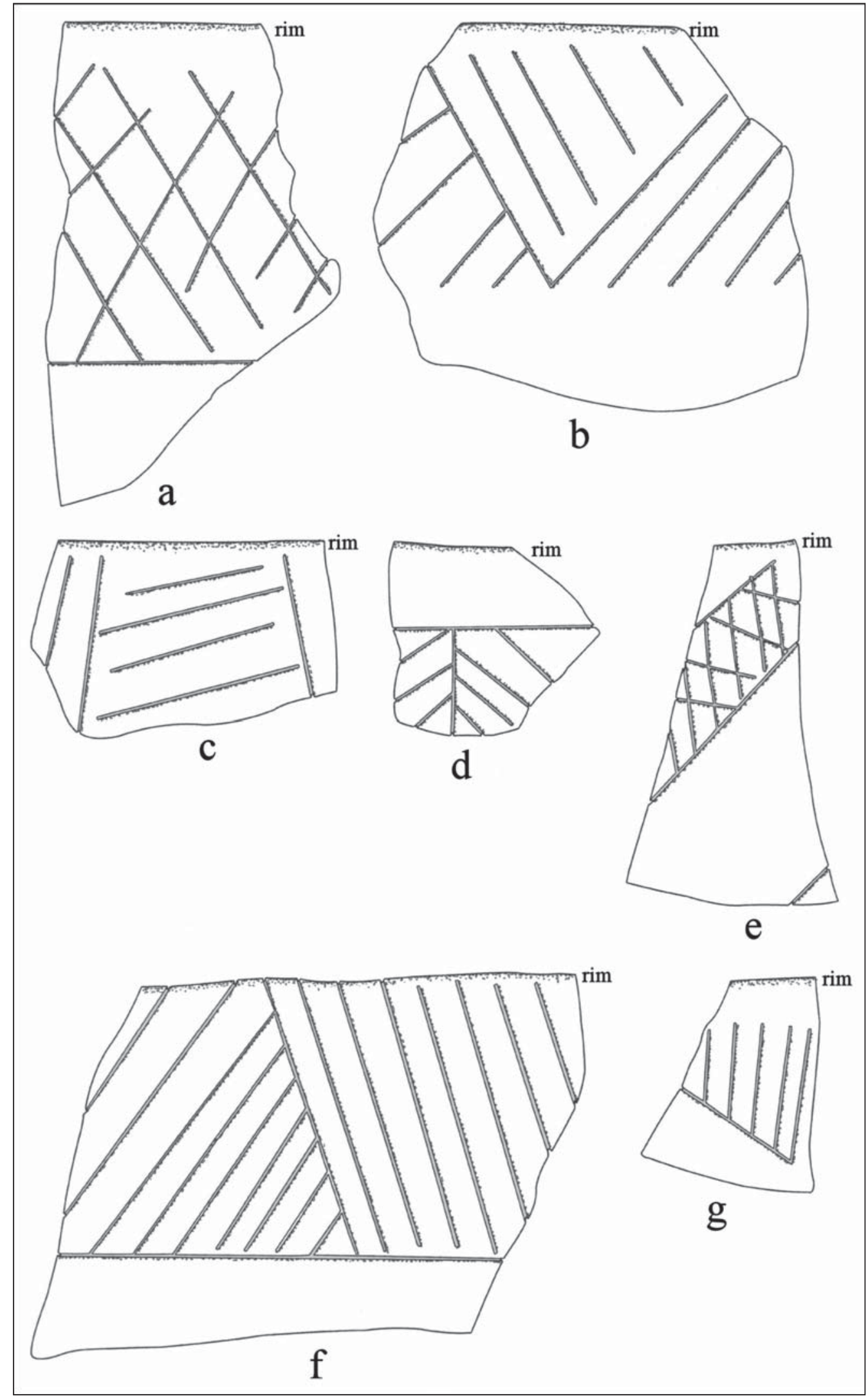

Figure 25. Decorative elements on incised rim sherds from the Sanders site. 
Table 13. Decorative elements on incised-punctated rim and body sherds.

\begin{tabular}{|c|c|c|c|c|c|c|c|}
\hline \multirow[b]{2}{*}{ Decorative element } & \multicolumn{2}{|c|}{ grog } & \multicolumn{2}{|c|}{ bone } & \multicolumn{2}{|c|}{ shell } & \multirow[b]{2}{*}{$\mathrm{N}$} \\
\hline & rim & body & rim & body & rim & body & \\
\hline $\begin{array}{l}\text { cross-hatched lines on the rim and } \\
\text { fingernail punctated rows on } \\
\text { upper body }\end{array}$ & 1 & - & - & - & - & - & 1 \\
\hline $\begin{array}{l}\text { diagonal lines pitched } \mathrm{L} \text { to } \mathrm{R} \text { and } \\
\text { fingernail punctated row at rim- } \\
\text { body juncture }\end{array}$ & - & 1 & - & - & - & - & 1 \\
\hline $\begin{array}{l}\text { diagonal opposed incised triangles } \\
\text { filled with tool punctates }\end{array}$ & 3 & - & - & - & - & - & 3 \\
\hline $\begin{array}{l}\text { horizontal and diagonal lines and } \\
\text { tool punctated row at rim-body } \\
\text { juncture }\end{array}$ & - & - & 1 & - & - & - & 1 \\
\hline $\begin{array}{l}\text { horizontal lines and incised } \\
\text { triangles filled with tool } \\
\text { punctates }\end{array}$ & 2 & 1 & - & - & - & - & 3 \\
\hline $\begin{array}{l}\text { incised triangle filled with } \\
\text { cane punctates }\end{array}$ & - & - & 1 & - & - & - & 1 \\
\hline $\begin{array}{l}\text { incised triangle filled with } \\
\text { circular punctates }\end{array}$ & 1 & 4 & - & - & - & - & 5 \\
\hline $\begin{array}{l}\text { incised triangle filled with } \\
\text { fingernail punctates }\end{array}$ & - & 1 & - & - & - & - & 1 \\
\hline $\begin{array}{l}\text { incised triangle filled with tool } \\
\text { punctates }\end{array}$ & - & 4 & - & 1 & - & - & 5 \\
\hline $\begin{array}{l}\text { incised triangle and tool } \\
\text { punctated zone }\end{array}$ & - & 1 & - & 1 & - & - & 2 \\
\hline $\begin{array}{l}\text { opposed lines and fingernail } \\
\text { punctated row }\end{array}$ & - & 1 & - & - & - & - & 1 \\
\hline $\begin{array}{l}\text { opposed lines and tool punctated } \\
\text { rows between lines }\end{array}$ & - & 1 & - & - & - & - & 1 \\
\hline $\begin{array}{l}\text { parallel incised and fingernail } \\
\text { punctated rows }\end{array}$ & - & - & - & 1 & - & - & 1 \\
\hline $\begin{array}{l}\text { vertical incised panels filled with } \\
\text { tool punctates }\end{array}$ & - & 2 & - & - & - & - & 2 \\
\hline Totals & 7 & 16 & 2 & 3 & - & - & 28 \\
\hline
\end{tabular}

L=left; R=right 


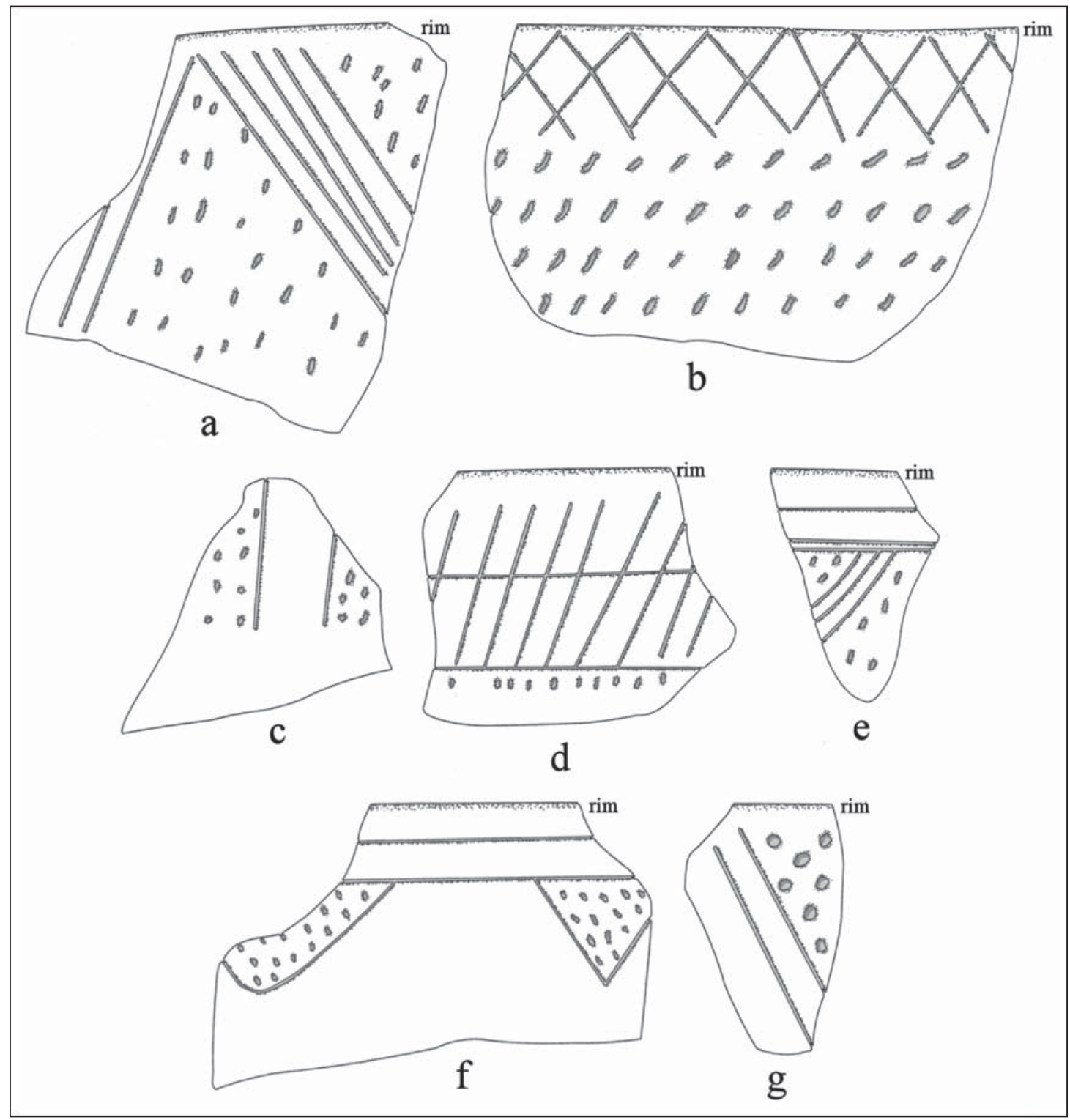

Figure 26. Decorative elements on incised-punctated rim and body sherds from the Sanders site: a-b, d-g, rim; c, body.

The few lip notched rim sherds ( $\mathrm{n}=6,0.9$ percent of the decorated sherds) are from a non-red-slipped variant of Sanders Plain (see Suhm and Jelks 1962:139). One of the two shell-tempered Nash Neck Banded rim sherds has six horizontal rows of neck bands on the rim and vertical appliqued ridges on the vessel body, while the other simply has horizontal neck bands.

The pinched body sherds have both straight and curvilinear pinched ridges. One grog-tempered body sherd from a Monkstown Fingernail Impressed jar has opposed pinched rows.

There are both grog-tempered (76.6 percent), bone-tempered (10.6 percent), and shell-tempered (12.8 percent) sherds with punctated decorative elements (Table 14). The shell-tempered sherds are from Emory Punctated-Incised jars. The fingernail impressed rim and body sherds (Figure 27a-b), which comprise 66 percent of the punctated sherd sample, are from Monkstown Fingernail Impressed jars (see Suhm and Jelks 1962:Plate 55). The vessels decorated with either square to triangular tool or circular tool punctates may 
be from an as yet undefined utility ware type made by ancestral Caddo potters in the upper part of the East Texas Red River basin.

Table 14. Decorative elements on punctated rim and body sherds.

\begin{tabular}{|c|c|c|c|c|c|c|c|}
\hline \multirow[b]{2}{*}{ Decorative element } & \multicolumn{2}{|c|}{ grog } & \multicolumn{2}{|c|}{ bone } & \multicolumn{2}{|c|}{ shell } & \multirow[b]{2}{*}{$\mathrm{N}$} \\
\hline & rim & body & rim & body & rim & body & \\
\hline circular punctated rows & 4 & 5 & 1 & - & - & - & 10 \\
\hline fingernail impressed rows & 2 & 15 & 1 & 2 & 1 & 5 & 26 \\
\hline $\begin{array}{l}\text { fingernail punctated, opposed } \\
\text { rows }\end{array}$ & - & 1 & - & - & - & - & 1 \\
\hline $\begin{array}{l}\text { fingernail punctated, straight and } \\
\text { opposed rows }\end{array}$ & - & 4 & - & - & - & - & 4 \\
\hline tool punctated rows & 1 & 4 & - & 1 & - & - & 6 \\
\hline Totals & 7 & 29 & 2 & 3 & 1 & 5 & 47 \\
\hline
\end{tabular}

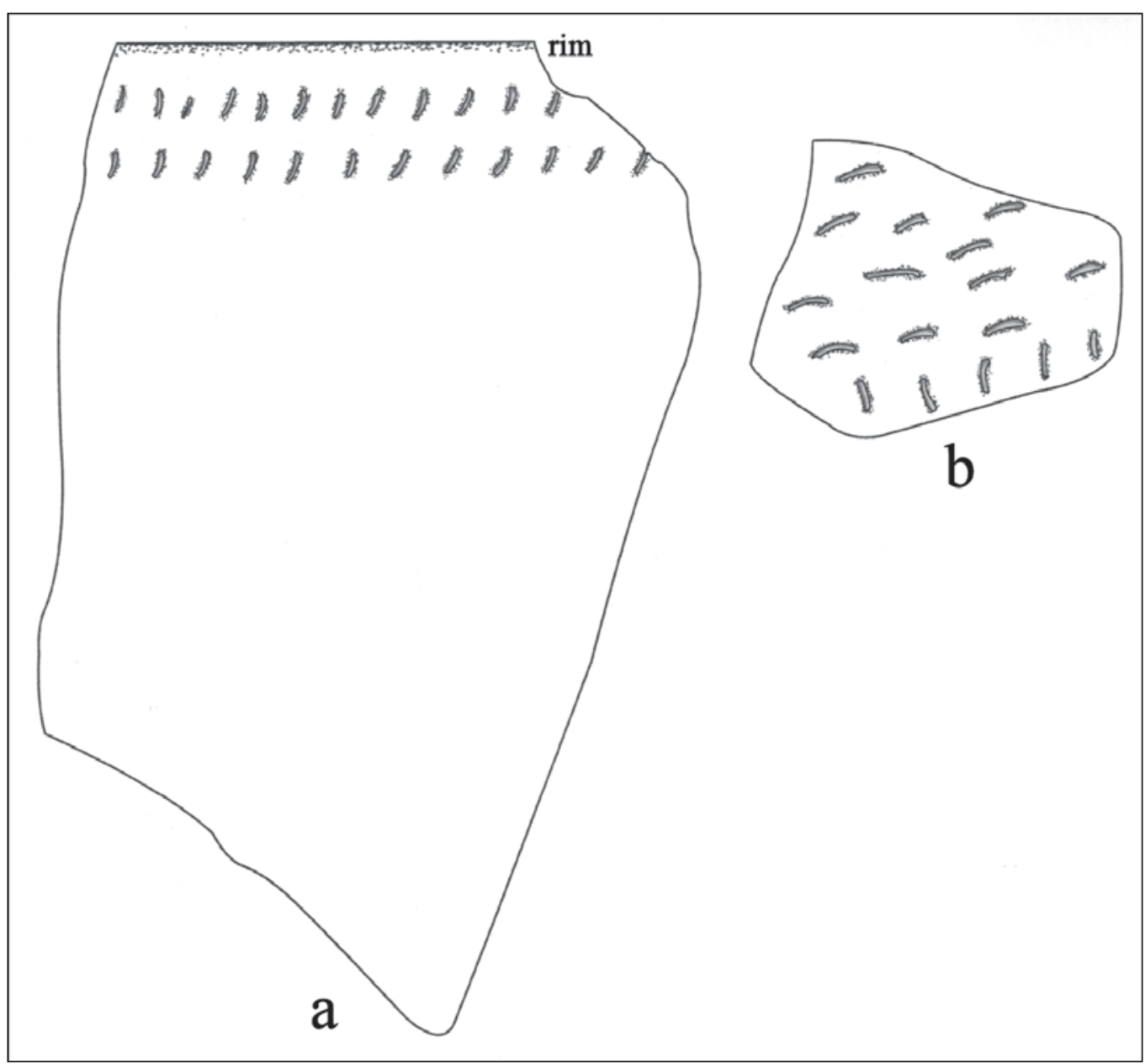

Figure 27. Decorative elements on punctated rim and body sherds from the Sanders site. 


\section{Fine Wares}

The fine ware sherds in the non-mound TARL collections from the Sanders site include bottle sherds with engraved decorative elements; engraved bowl and carinated bowl sherds (some of which have redslipped surfaces) (Table 15) from a variety of types and with a diverse range of decorative elements; sherds from red-slipped vessels; and red-slipped sherds with appliqued or punctated decorative elements. These latter sherds account for only 1.4 percent of the fine wares, compared to 39.5 percent of the fine ware that are solely decorated with a red slip, and the remaining 59.1 percent of the fine ware sherds have engraved decorative elements. Engraved sherds from vessels with a red-slipped surface account for 9.4 percent of the grog- and bone-tempered sherds and 23.5 percent of the shell-tempered sherds.

Table 15. Decorative elements on engraved rim and body sherds.

\begin{tabular}{|c|c|c|c|c|c|c|c|}
\hline \multirow[b]{2}{*}{ Decorative element } & \multicolumn{2}{|c|}{ grog } & \multicolumn{2}{|c|}{ bone } & \multicolumn{2}{|c|}{ shell } & \\
\hline & rim & body & rim & body & rim & body & $\mathrm{N}$ \\
\hline
\end{tabular}

\section{Bottle Sherds}

cross-hatched zone

cross-hatched triangles

curvilinear lines, bottle

hatched zone, bottle

curvilinear hatched and cross-

hatched zones

horizontal lines, bottle neck

opposed curvilinear lines

Subtotal, engraved bottle

$\begin{array}{lcl}- & - & - \\ - & 6 & - \\ - & - & - \\ - & 1 & - \\ - & 2 & - \\ & & - \\ - & 2 * * * & - \\ - & 12 & \end{array}$

$\begin{array}{ll}- & 1 \\ - & - \\ - & - \\ - & -\end{array}$

$1 \quad-$

$\begin{array}{lll}- & - & 1\end{array}$

$-$

$-$

$-$

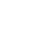

-

-

$-$

- 6

$\begin{array}{ll}- & 1\end{array}$

- 1

$-$

- 2

Bowl and Carinated Bowl Sherds

cross-hatched lines
cross-hatched and horizontal lines
cross-hatched zone
cross-hatched zone, diagonal
cross-hatched triangle
curvilinear lines
curvilinear arcing lines and
excised pendant triangles
curvilinear and straight lines
diagonal lines, pitched L to R
diagonal lines, pitched R to L
diagonal lines, pitched R to L and
hatched pendant triangles
diagonal opposed lines
diagonal opposed lines, open
triangle

hatched zone

hatched triangles

$1+$
1
1
1
-

$-\quad 2$

$\begin{array}{ll}- & 2 \\ - & 1\end{array}$

$\begin{array}{ll}- & 1\end{array}$

12

$22 * \quad 3$

1

23

$4-$

-

1

-
-
-
-
-
1
-
-

\begin{tabular}{|c|c|}
\hline- & - \\
\hline- & - \\
\hline- & - \\
\hline- & - \\
\hline- & - \\
\hline- & - \\
\hline- & - \\
\hline- & - \\
\hline- & - \\
\hline- & - \\
\hline- & - \\
\hline- & - \\
\hline- & - \\
\hline 1 & - \\
\hline- & - \\
\hline
\end{tabular}


Table 15. Decorative elements on engraved rim and body sherds, cont.

\begin{tabular}{|c|c|c|c|c|c|c|c|}
\hline \multirow[b]{2}{*}{ Decorative element } & \multicolumn{2}{|c|}{ grog } & \multicolumn{2}{|c|}{ bone } & \multicolumn{2}{|c|}{ shell } & \multirow[b]{2}{*}{$\mathrm{N}$} \\
\hline & rim & body & rim & body & rim & body & \\
\hline horizontal lines & 1 & 3 & - & 2 & - & - & 6 \\
\hline $\begin{array}{l}\text { horizontal line and cross-hatched } \\
\text { bracket }\end{array}$ & - & 1 & - & - & - & - & 1 \\
\hline $\begin{array}{l}\text { horizontal line and cross-hatched } \\
\text { zone }\end{array}$ & 1 & - & - & - & - & $1++$ & 2 \\
\hline $\begin{array}{l}\text { horizontal and opposed } \\
\text { curvilinear lines }\end{array}$ & 1 & 1 & - & - & - & - & 2 \\
\hline horizontal and diagonal lines & $1+$ & 2 & - & - & - & - & 3 \\
\hline $\begin{array}{l}\text { horizontal and diagonal opposed } \\
\text { lines }\end{array}$ & - & - & - & 2 & - & - & 2 \\
\hline $\begin{array}{l}\text { horizontal lines and hatched } \\
\text { pendant triangles }\end{array}$ & 1 & 1 & - & - & - & - & 2 \\
\hline $\begin{array}{l}\text { horizontal lines and open } \\
\text { triangle el. }\end{array}$ & 1 & - & - & - & - & - & 1 \\
\hline $\begin{array}{l}\text { nested triangle and horizontal } \\
\text { line with tick marks }\end{array}$ & 1 & - & - & - & - & - & 1 \\
\hline opposed lines & - & 2 & - & - & - & - & 2 \\
\hline parallel lines & - & 5 & - & - & - & $1++$ & 6 \\
\hline parallel lines and hatched zone & - & 1 & - & - & - & - & 1 \\
\hline slanting scroll elements & 10 & - & - & - & - & - & 10 \\
\hline slanting scroll and hatched zone & 1 & 1 & - & - & - & - & 2 \\
\hline $\begin{array}{l}\text { scroll, horizontal and excised } \\
\text { brackets }\end{array}$ & 1 & - & - & - & - & - & 1 \\
\hline straight line & - & 1 & - & 1 & - & 1 & 3 \\
\hline $\begin{array}{l}\text { straight line and excised } \\
\text { pendant triangle }\end{array}$ & - & 1 & - & - & - & - & 1 \\
\hline vertical lines & 2 & - & - & - & - & - & 2 \\
\hline $\begin{array}{l}\text { vertical lines and cross-hatched } \\
\text { vertical zones }\end{array}$ & - & 1 & - & - & - & - & 1 \\
\hline vertical and sets of horizontal lines & 1 & - & - & - & - & - & 1 \\
\hline zig-zag lines & - & 1 & - & - & - & - & 1 \\
\hline Subtotal & 63 & 38 & 14 & 6 & 1 & 3 & 125 \\
\hline \multicolumn{8}{|l|}{ Avery Engraved } \\
\hline $\begin{array}{l}\text { curvilinear hatched zone and } \\
\text { negative oval }\end{array}$ & - & - & - & - & - & 1 & 1 \\
\hline $\begin{array}{l}\text { diagonal lines, one with tick } \\
\text { marks }\end{array}$ & - & - & - & - & - & $1++$ & 1 \\
\hline
\end{tabular}


Table 15. Decorative elements on engraved rim and body sherds, cont.

\begin{tabular}{|c|c|c|c|c|c|c|c|}
\hline \multirow[b]{2}{*}{ Decorative element } & \multicolumn{2}{|c|}{ grog } & \multicolumn{2}{|c|}{ bone } & \multicolumn{2}{|c|}{ shell } & \multirow[b]{2}{*}{$\mathrm{N}$} \\
\hline & rim & body & rim & body & rim & body & \\
\hline $\begin{array}{l}\text { horizontal and curvilinear } \\
\text { lines, negative excised } \\
\text { oval, and curvilinear } \\
\text { ticked line }\end{array}$ & - & - & - & - & - & $1++$ & 1 \\
\hline Subtotal, Avery Engraved & - & - & - & - & - & 3 & 3 \\
\hline \multicolumn{8}{|l|}{ Hudson Engraved } \\
\hline $\begin{array}{l}\text { curvilinear scroll filled with } \\
\text { incised lines }\end{array}$ & - & - & - & - & - & 1 & 1 \\
\hline $\begin{array}{l}\text { curvilinear and hooked arm } \\
\text { scrolls filled with incised lines }\end{array}$ & - & - & - & - & - & 1 & 1 \\
\hline Subtotal, Hudson Engraved & - & - & - & - & - & 2 & 2 \\
\hline
\end{tabular}

\section{Patton Engraved}

curvilinear lines with tick marks

\section{Simms Engraved}

horizontal panel with tick marks and hatched pendant triangles

horizontal and discontinuous

scroll with tick marks

horizontal and vertical lines and

circular excised punctates; lip

notched

horizontal and vertical scroll with

tick marks; lip notched

vertical excised bracket, and

horizontal panel line

Subtotal, Simms Engraved

\section{Womack Engraved}

cross-hatched bracket and open zones 1

cross-hatched zones

cross-hatched zones and tick marks

cross-hatched triangle zone

curvilinear element with tick

marks and cross-hatched zone

curvilinear line with tick marks

and hatched triangle

horizontal, curvilinear, and

opposed vertical line-filled zone

scroll element

scroll with hooked arm element and hatched fill zones 
Table 15. Decorative elements on engraved rim and body sherds, cont.

\begin{tabular}{|c|c|c|c|c|c|c|c|}
\hline \multirow[b]{2}{*}{ Decorative element } & \multicolumn{2}{|c|}{ grog } & \multicolumn{2}{|c|}{ bone } & \multicolumn{2}{|c|}{ shell } & \multirow[b]{2}{*}{$\mathrm{N}$} \\
\hline & rim & body & rim & body & rim & body & \\
\hline $\begin{array}{l}\text { slanted scroll with ticked scroll } \\
\text { line and cross-hatched fill zones }\end{array}$ & 2 & - & - & - & - & - & 2 \\
\hline $\begin{array}{l}\text { slanted scroll and cross-hatched } \\
\text { fill zones }\end{array}$ & 2 & - & - & - & - & - & 2 \\
\hline $\begin{array}{l}\text { slanted scroll, cross-hatched fill } \\
\text { zones and negative oval }\end{array}$ & 1 & - & - & - & - & - & 1 \\
\hline slanted scroll with hatched fill zone & 1 & - & - & - & - & - & 1 \\
\hline tick marks on line & - & 3 & - & - & - & 1 & 4 \\
\hline triangle element & - & 1 & - & - & - & - & 1 \\
\hline triangle element and oval & - & - & - & 1 & - & - & 1 \\
\hline triangle element and tick marks & - & 1 & - & - & - & - & 1 \\
\hline Subtotal, Womack Engraved & 13 & 38 & 3 & 4 & - & 2 & 60 \\
\hline Totals & 76 & 89 & 17 & 11 & 5 & 12 & 210 \\
\hline
\end{tabular}

L=left; R=right

*includes 11 rim sherds with interior/exterior red-slipped surfaces and one lip notched rim

**includes four rim sherds with interior/exterior red-slipped surfaces

***two sherds with exterior red-slipped surface

+includes one rim with interior/exterior red-slipped surface

++one body sherd with interior/exterior red-slipped surface

The rims of most of the sherds from fine ware bowls and carinated bowls are primarily from Sanders Engraved vessels (see Suhm and Jelks 1962:Plate 69) with diagonal and diagonal opposed lines ( $\mathrm{n}=42$ ) (Figure 28d), most pitched from right to left, hatched triangle elements (n=8, Figure 28e-f), horizontal and diagonal lines and other elements (Figure 28c, g-h), hatched diagonal panels (Figure 28i), and cross-hatched lines (Figure 28a). Three rims have sets of vertical engraved lines, either as the sole decorative element, or in association with horizontal engraved lines (see Table 15).

Another distinctive grog-tempered engraved fine ware in the TARL sherd assemblage from the Sanders site has slanted scrolls (Figure 29b-c, e-f) with various upper and lower scroll fill zones: excised and open brackets, sets of vertical lines, and curvilinear lines. These scroll decorative elements are very different from the scrolls noted on Womack Engraved carinated bowls (see below), and it is not clear if this particular fine ware is part of the Middle Caddo ceramic assemblage at the site, or is a distinctive part of a later Late to Historic Caddo period settlement that is widely distributed at the Sanders site. For the moment, we have dubbed the scroll decorative element on fine ware rim sherds as belonging to a new type: Bois d'Arc Engraved vessels.

There are two other distinctive grog-tempered rims from the site. The first has a horizontal scroll with stacked nested triangles (see Figure 29a), while the second rim has nested triangles (or widely spaced diagonal opposed lines) on a carinated bowl, with a small excised triangle at the apex of one triangle, along with a row of downward-pointing tick marks on a single horizontal engraved line underlying the lip (see Figure 29d).

Although they are not common (i.e., only 8.1 percent of the fine wares are from shell-tempered vessels), most of the few shell-tempered engraved fine ware sherds are from Avery Engraved (Figure 30a-c), Hudson Engraved (Figure 30d-e), and Simms Engraved vessels (Figure 31a-d; see also Table 15); one sherd is from an engraved bottle. Two of the Simms Engraved rim sherds are lip notched (see Table 15). These vessels 


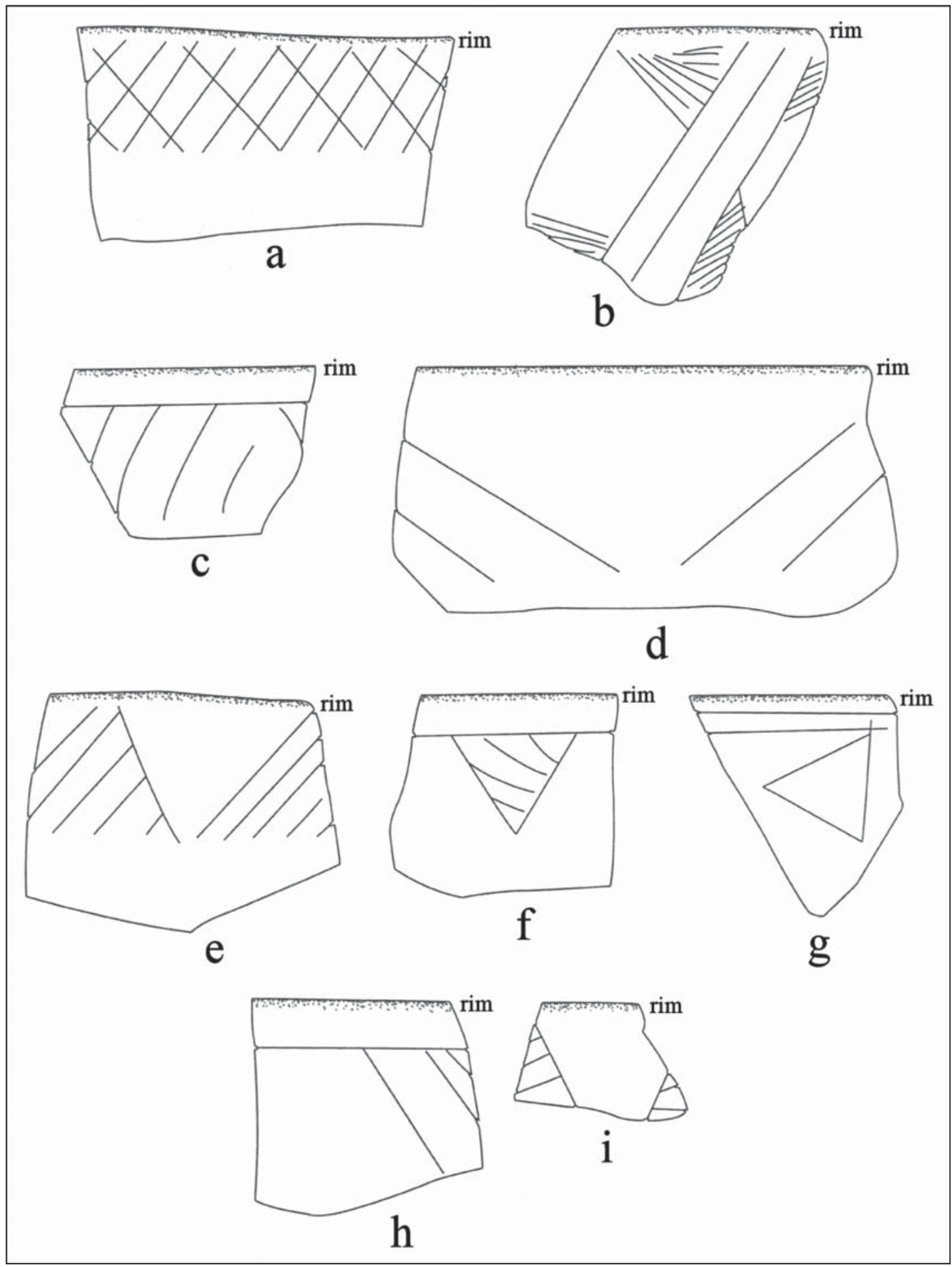

Figure 28. Decorative elements on probable Sanders Engraved rim sherds from the Sanders site.

may be trade wares obtained from post-A.D. 1600 McCurtain phase Caddo groups living downstream on the Red River, near the confluence of the Kiamichi and Red rivers. Two other shell-tempered sherds have Womack Engraved decorative elements (see Table 15), although more than 97 percent of the Womack Engraved sherds in the TARL collections from the Sanders site are from grog- and bone-tempered vessels. 


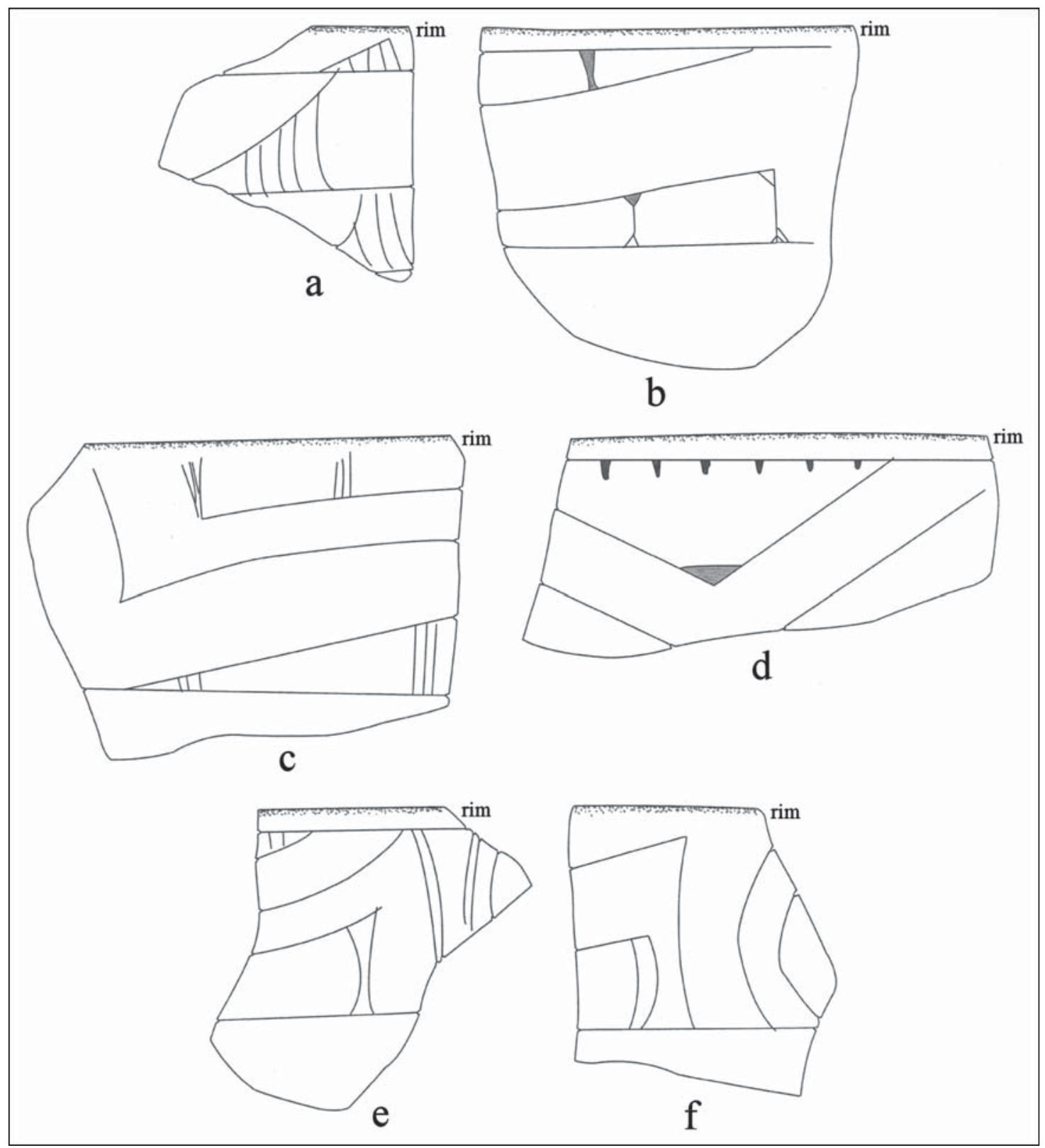

Figure 29. Decorative elements on scroll engraved rim sherds from the Sanders site.

There is one post-A.D. 1650 grog-tempered Patton Engraved body sherd in the Sanders site collection (see Table 15). It is either from a var. Freeman or var. Fair vessel that was likely made by an upper Neches River basin Caddo group (see Perttula 2011:Figure 6-66c-d).

There are 58 grog- and bone-tempered Womack Engraved rim and body sherds in the TARL collections; Womack Engraved rim sherds are about half as common as grog- and bone-tempered Sanders Engraved rim sherds (see Table 15), but they represent a secondary fine ware ceramic ware in use at the site, probably beginning in the latter part of the 17th early and extending into the early 18th century. The majority of the Womack Engraved sherds are from vessels with negative meandering scrolls with a central ticked line (or central unticked line) and cross-hatched scroll fill zones (Figure 32c-e, g, k-l). There are also sherds with scrolls that end in hooked arm elements (Figure 32b, h) - these sherds would not be difficult to include in with the Bois d'Arc Engraved vessel sherds (see Figure 29c, e-f) as the scroll lines do not have tick marks - 


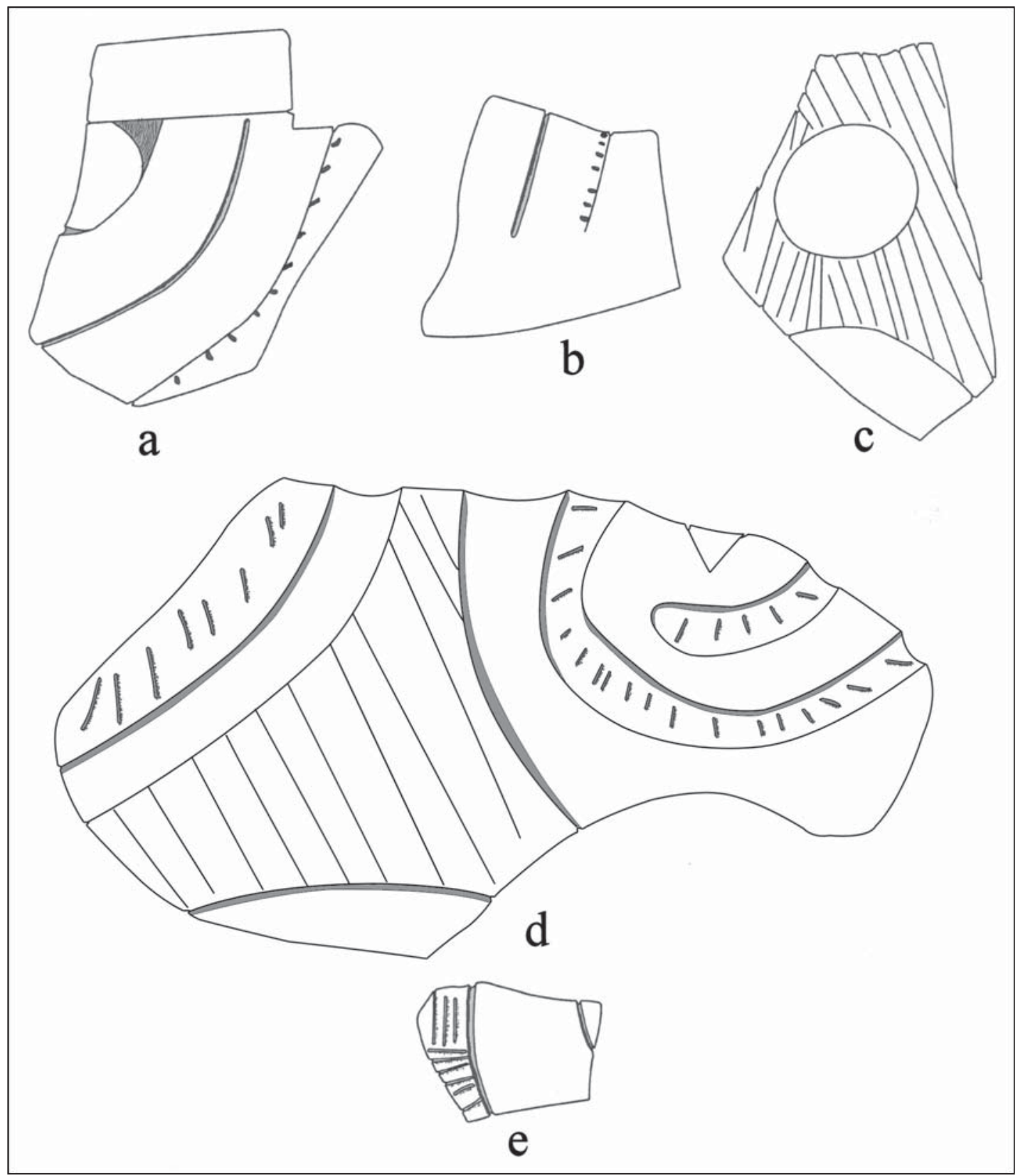

Figure 30. Decorative elements on Avery Engraved and Hudson Engraved body sherds from the Sanders site: a-c, Avery Engraved; d-e, Hudson Engraved.

slanting scrolls and a line with tick marks (Figure 32i), and sherds with cross-hatched zones and circular elements, either with or without tick marks (Figure 32f, j).

There is also a large rim sherd from a bone-tempered duck head effigy bowl in the collection; it was purchased from T. M. Sanders in 1931 by UT. In addition to the duck head applied to the interior side of the rim and that faces away from the vessel, the exterior surface of the rim is decorated with three broad horizontal engraved lines.

There are red-slipped rim and body sherds from all three tempered wares at the Sanders site, with grogtempered vessel sherds most common (70.3 percent) in the assemblage as a whole, followed by bone-tempered 


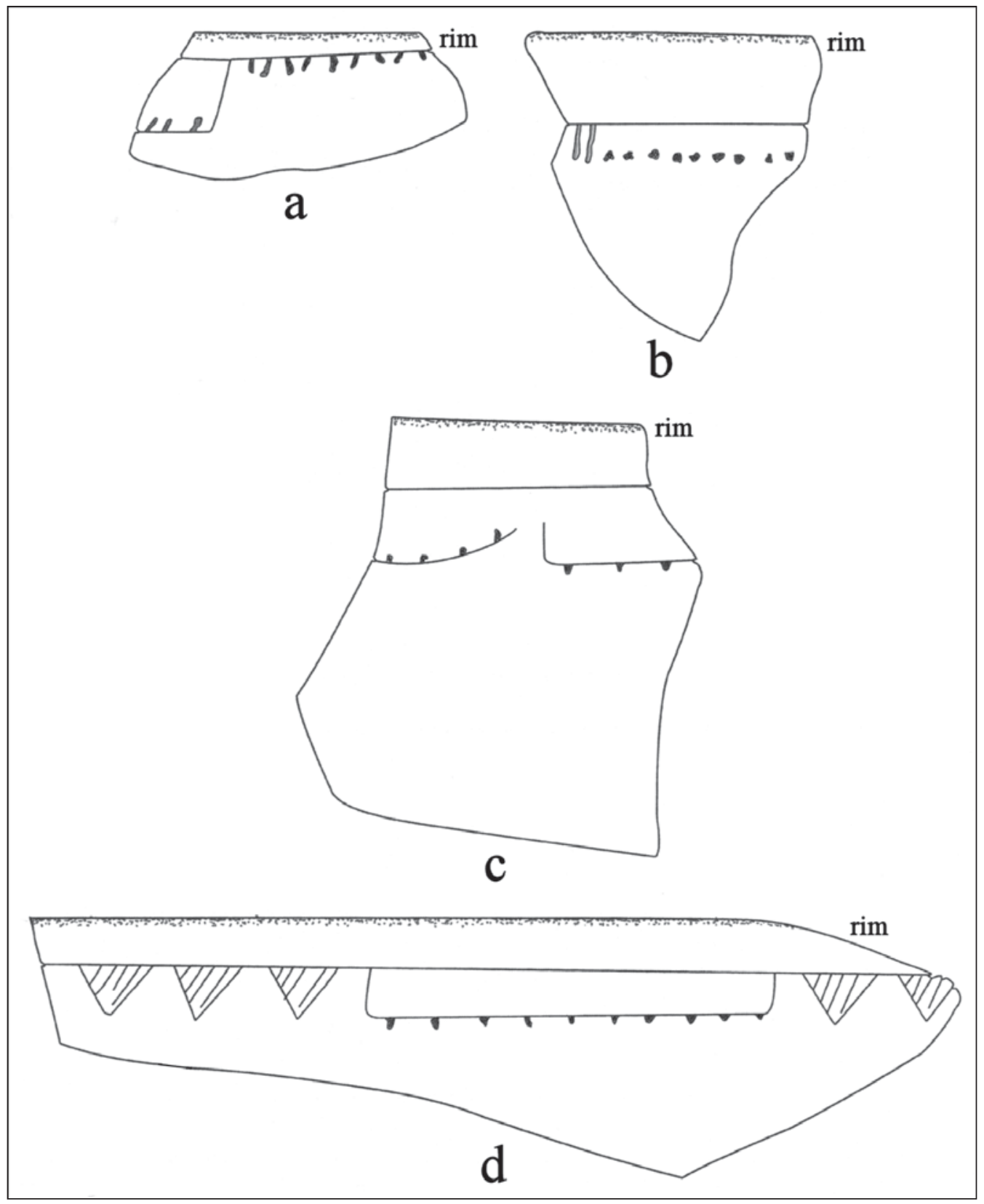

Figure 31. Decorative elements on Simms Engraved rim sherds from the Sanders site.

(24.1 percent), and shell-tempered (5.5 percent) (Table 16). The grog and bone-tempered sherds are from Sanders Plain vessels. The shell-tempered sherds may be from red-slipped Avery Engraved bottles and Clement Redware bowls. The proportion of engraved to red-slipped sherds in the grog-tempered wares is 1.6:1, compared to $0.8: 1$ for the bone-tempered wares, and 2.1:1 for the shell-tempered wares from the site; the proportion of red-slipped sherds in the fine wares is highest among the bone-tempered wares from the Sanders site.

The grog- and bone-tempered red-slipped bottle sherds $(\mathrm{n}=40)$ are likely from Maxey Noded Redware bottles (see Table 16). The remainder of the red-slipped sherds ( $n=97)$ are from Sanders Plain bowls and carinated bowls. Two of the rim sherds have either a scalloped or thickened lip. 


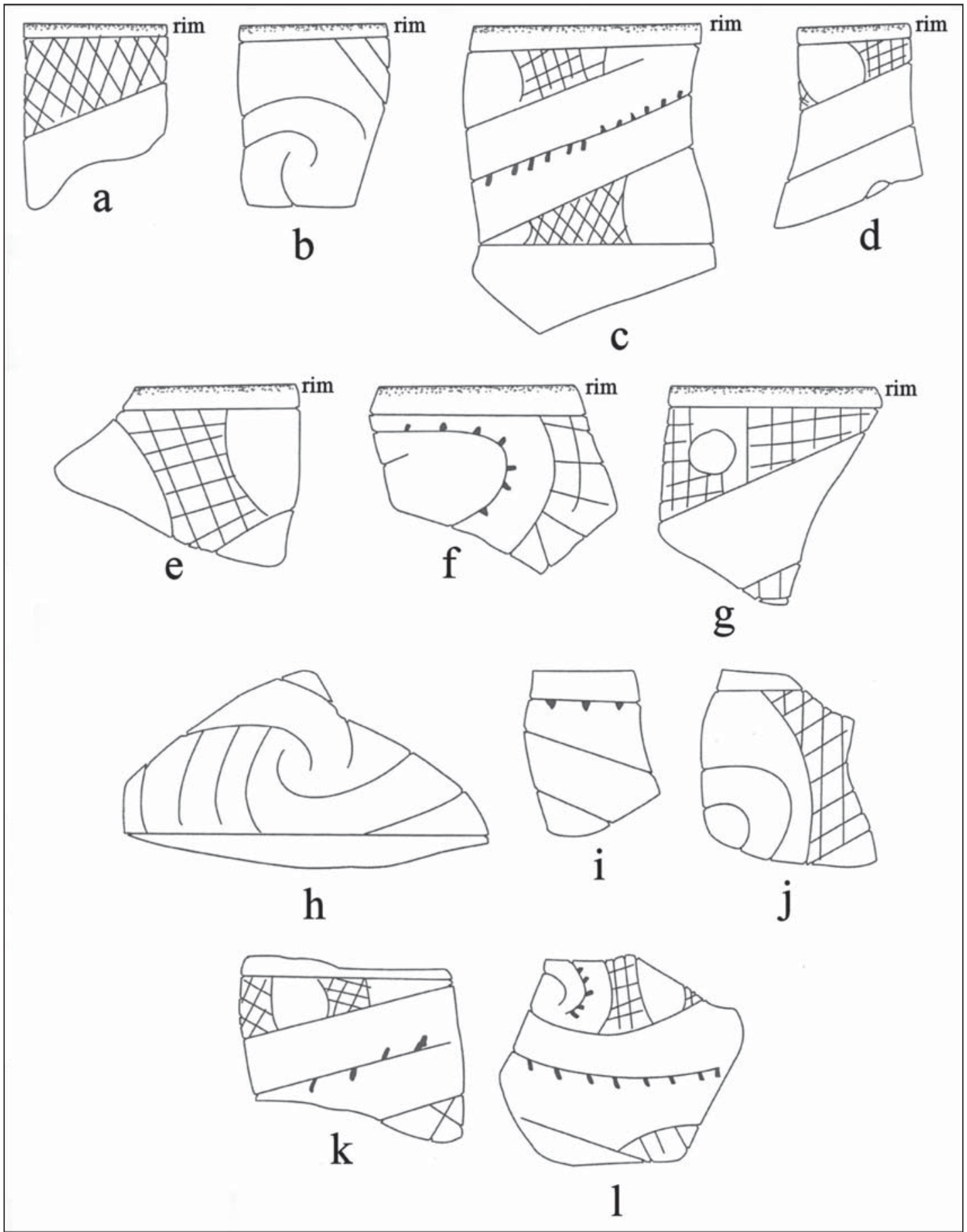

Figure 32. Decorative elements on Womack Engraved rim and body sherds from the Sanders site.

Four grog- and bone-tempered fine ware sherds (1.4 percent of the fine wares) in the TARL collections from the Sanders site are from Maxey Noded Redware vessels, both appliqued and punctated varieties (Suhm and Jelks 1962:101 and Plate 51c-d). These sherds are red-slipped on the exterior surface and have rows of small punctations $(n=4)$ excised through the red-slipped surface (Figure 33a-b). The one red-slipped/ appliqued sherd has a red slip on both interior and exterior surfaces, as well as an appliqued handle on its exterior surface. 
Table 16. Red-slipped rim and body sherds.

\begin{tabular}{lcccccrr}
\hline & \multicolumn{2}{c}{ grog } & \multicolumn{2}{c}{ bone } & \multicolumn{2}{c}{ shell } \\
Decorative element & rim & body & rim & body & rim & body & N \\
\hline ext. red-slipped & 1 & 9 & - & 1 & - & - & 11 \\
ext. red-slipped, thickened lip & 1 & - & - & - & - & - & 1 \\
ext. red-slipped, bottle & - & 25 & - & 15 & - & 1 & 41 \\
Subtotal & 2 & 34 & - & 16 & - & 1 & 53 \\
int./ext. red-slipped & 5 & 50 & - & 17 & - & 6 & 78 \\
int./ext. red-slipped, bowl & - & 2 & - & - & - & 1 & 3 \\
int./ext. red-slipped, carinated bowl & 8 & - & 1 & - & - & - & 9 \\
int./ext. red-slipped, scalloped & 1 & - & 1 & - & - & - & 2 \\
Subtotal & 14 & 52 & 2 & 17 & - & 7 & 92 \\
\hline Totals & 16 & 86 & 2 & 33 & - & 8 & 145 \\
\hline
\end{tabular}

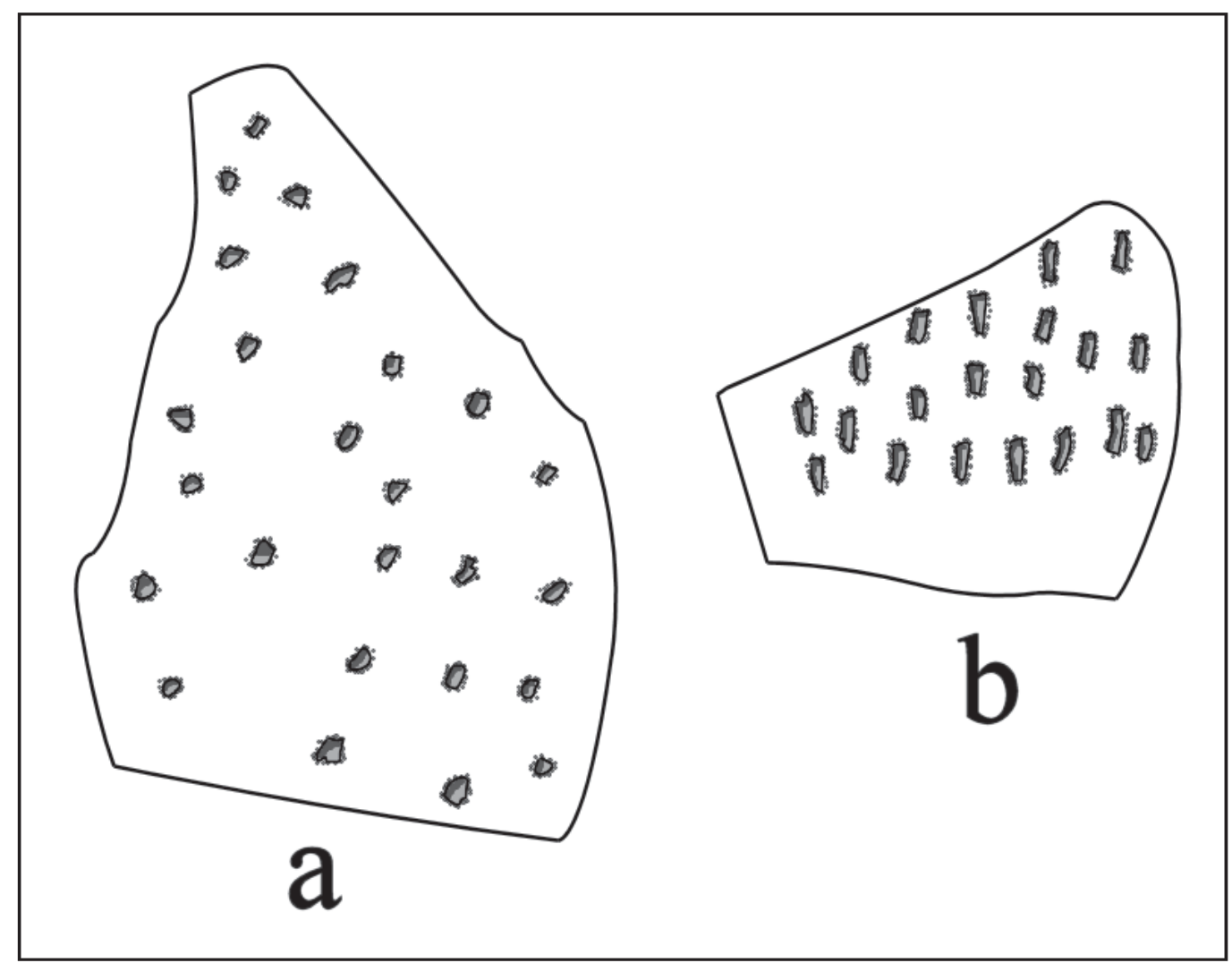

Figure 33. Maxey Noded Redware body sherds from the Sanders site.

\section{Spindle Whorl}

A plain grog-tempered base sherd has a centrally-drilled hole in it, indicating it was used as a spindle whorl. 


\section{Lithic Artifacts}

The Steen collection from the Sanders site has several chipped stone tools, almost all made on Ouachita Mountains chert. This includes three Woodland period Gary dart points (quartzite, $\mathrm{n}=2$ and chert, $\mathrm{n}=1$ ), six triangular Maud or Fresno arrow points (chert, $n=4$, quartzite, $n=1$, novaculite, $n=1$ ), 15 end and side scrapers (all chert), one dark gray chert beveled knife tip, and two dark gray chert bifacial drills. Another collection (Lot 13) from the Sanders site has 12 Maud or Fresno arrow points and two arrow point preforms; they are made on Ouachita Mountains cherts.

\section{SMITHSONIAN INSTITUTION COLLECTIONS FROM THE SANDERS SITE}

The National Museum of Natural History (NMNH) at the Smithsonian Institution has two collections of artifacts from the Sanders site: the R. King Harris and Joseph Long collections. Some of the artifacts from the Harris collection are from burial contexts (Harris's numbering system indicated that he excavated six burials at the Sanders site), but otherwise we presume the artifacts were collected from the surface of various areas at the site. There is no information available on the intra-site provenience of any of the artifacts in these two collections.

\section{Ceramic Vessels}

There are two whole vessels in the King Harris collection from the Sanders site. The first is a grogtempered Canton Incised jar with two lug handles from Burial 1. The rim has sets of opposed incised triangles with tool punctate-filled zones, and there are also three rows of fingernail punctations that extend below the incised-punctated triangles to the rim-body juncture (Figure 34). The jar is $11.8 \mathrm{~cm}$ in height, with a 10.9 $\mathrm{cm}$ orifice diameter, and a $6.1 \mathrm{~cm}$ base diameter. The base is flat and the rim is direct, with a flat lip.

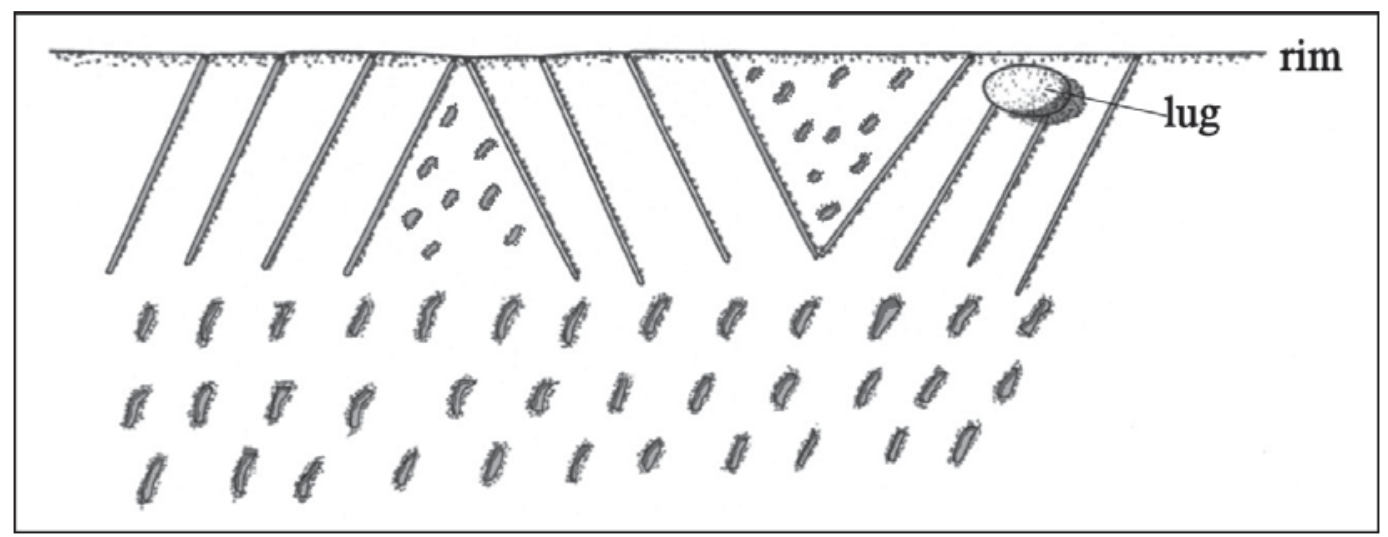

Figure 34. Decorative element on Canton Incised jar in Burial 1, R. King Harris Collection at the NMNH.

The second whole vessel is a repaired and restored grog-tempered red-slipped Sanders Plain bowl with two lip lugs, from an unknown burial provenience. The bowl is $10.5 \mathrm{~cm}$ in height, $18.3 \mathrm{~cm}$ in orifice diameter, and has a flat base $9.0 \mathrm{~cm}$ in diameter; the red slip has mostly been eroded from the vessel surfaces. 


\section{Ceramic Sherds}

The analysis of the ceramic sherds from the Sanders site in the NMNH collection focused on the decorated sherds $(n=265)$, except for a small sample of plain rim sherds (Table 17). About 68 percent of the sherds are from grog-tempered vessels; another 13 percent are from bone-tempered vessels; and about 19 percent are from shell-tempered vessels. Among the 265 decorated sherds, 42 percent are from utility wares, with the remaining 58 percent of the sherds from engraved, red-slipped, and trailed fine wares.

Table 17. Ceramic Sherds in the National Museum of Natural History, Smithsonian Institution, from the Sanders site (41LR2).

\begin{tabular}{lccccccc}
\hline & \multicolumn{2}{c}{ grog } & \multicolumn{2}{c}{ bone } & \multicolumn{2}{c}{ shell } \\
Decorative element & rim & body & rim & body & rim & body & N \\
\hline Plain ware & 17 & - & 3 & - & 4 & - & 24
\end{tabular}

Utility ware

\begin{tabular}{lrrrrrrr} 
appliqued & 1 & 8 & - & 1 & 1 & 3 & 14 \\
appliqued-punctated & - & - & - & 1 & - & - & 1 \\
brushed & 1 & - & - & - & - & - & 1 \\
corn cob impressed & - & 2 & - & - & - & - & 2 \\
incised & 11 & 14 & 1 & 2 & - & 1 & 29 \\
incised-punctated & 1 & 3 & - & - & - & 1 & 5 \\
lip notched & 3 & - & - & - & - & - & 3 \\
neck banded & 6 & 4 & 1 & 1 & 2 & 7 & 21 \\
pinched & - & - & - & 1 & - & - & 1 \\
punctated, cane & - & 1 & - & - & - & - & 1 \\
punctated, circular & 1 & 1 & - & 1 & - & - & 3 \\
punctated, fingernail & 3 & 9 & 3 & 4 & 4 & 1 & 24 \\
punctated, tool & 2 & 2 & - & 1 & - & 1 & 6 \\
Subtotal & 29 & 44 & 5 & 12 & 7 & 14 & 111 \\
Fine ware & & & & & & & \\
engraved & & & & & & 10 & 96 \\
red-slipped & 30 & 42 & - & 8 & 6 & 11 \\
trailed & 7 & 22 & 2 & 9 & 1 & 6 & 47 \\
Subtotal & - & 5 & - & - & - & 6 & 11 \\
\hline Totals & 37 & 71 & 2 & 17 & 7 & 22 & 154 \\
\hline
\end{tabular}

Utility ware sherds account for only 41 percent of the decorated sherds in this assemblage from the Sanders site. The most common decorative methods represented in the utility wares include sherds from incised (26.3 percent), fingernail punctated (21.8 percent), neck banded (19.1 percent), and appliqued (12.8 percent) vessels (see Table 17). Fine wares comprise 59 percent of the decorated sherds, divided between engraved (62.8 percent), red-slipped (30.1 percent), and trailed ( 7.0 percent); the abundance of sherds from red-slipped vessels (grog- and bone-tempered as well as shell-tempered) is notable (see Table 17). Sherds from vessels with trailed decorative elements (i.e., Keno Trailed) are disproportionally from shell-tempered vessels (54.5 percent of the trailed sherds). 
Table 18. Decorative elements in the utility ware sherds from the Sanders site in the NMNH collection.

\begin{tabular}{lcccccrr}
\hline & \multicolumn{2}{c}{ grog } & \multicolumn{2}{c}{ bone } & \multicolumn{2}{c}{ shell } \\
Decorative element & rim & body & rim & body & rim & body & $\mathrm{N}$ \\
\hline Appliqued & & & & & & & \\
horizontal ridge & 1 & - & - & - & - & - & 1 \\
node & - & 1 & - & - & 1 & - & 2 \\
parallel fillets & - & 1 & - & - & - & 2 & 3 \\
parallel ridges & - & 2 & - & - & - & - & 2 \\
straight fillet & - & 1 & - & - & - & - & 1 \\
straight ridge & - & 2 & - & 1 & - & - & 3 \\
triangular ridge el. & - & 1 & - & - & - & 1 & 2 \\
Subtotal & 1 & 8 & - & 1 & 1 & 3 & 14
\end{tabular}

\section{Appliqued-Punctated}

vertical fillet [body],

tool punctated row at

rim-body juncture

\section{Brushed}

horizontal marks

\section{Corn Cob Impressed}

parallel impressions

\section{Incised}

cross-hatched lines

diagonal lines,

$\mathrm{R}$ to $\mathrm{L}$

diagonal lines,

$\mathrm{L}$ to $\mathrm{R}$

diagonal opposed lines

hatched zone

horizontal lines

horizontal and diagonal

lines

opposed lines

parallel lines

straight lines

Subtotal

1 
Table 18. Decorative elements in the utility ware sherds from the Sanders site in the NMNH collection, cont.

\begin{tabular}{|c|c|c|c|c|c|c|c|}
\hline \multirow[b]{2}{*}{ Decorative element } & \multicolumn{2}{|c|}{ grog } & \multicolumn{2}{|c|}{ bone } & \multicolumn{2}{|c|}{ shell } & \multirow[b]{2}{*}{$\mathrm{N}$} \\
\hline & rim & body & rim & body & rim & body & \\
\hline $\begin{array}{l}\text { horizontal lines and } \\
\text { vertical panel, one } \\
\text { filled with cane } \\
\text { punctates }\end{array}$ & 1 & - & - & - & - & - & 1 \\
\hline $\begin{array}{l}\text { vertical and curvilinear } \\
\text { incised zones and semi- } \\
\text { circular and bracket } \\
\text { zones with tool } \\
\text { punctates }\end{array}$ & - & 1 & - & - & - & - & 1 \\
\hline $\begin{array}{l}\text { vertical tool punctated } \\
\text { row between diagonal } \\
\text { incised panels }\end{array}$ & - & 1 & - & - & - & - & 1 \\
\hline $\begin{array}{l}\text { vertical tool punctated } \\
\text { panels between vertical } \\
\text { lines }\end{array}$ & - & 1 & - & - & - & - & 1 \\
\hline Subtotal & 1 & 3 & - & - & - & 1 & 5 \\
\hline \multicolumn{8}{|l|}{ Lip notched } \\
\hline on rim & 3 & - & - & - & - & - & 3 \\
\hline \multicolumn{8}{|l|}{ Neck banded } \\
\hline horizontal coils & 6 & 4 & 1 & 1 & 2 & 7 & 21 \\
\hline \multicolumn{8}{|l|}{ Pinched } \\
\hline pinched rows & - & - & - & 1 & - & - & 1 \\
\hline \multicolumn{8}{|l|}{ Punctated } \\
\hline cane rows & - & 1 & - & - & - & - & 1 \\
\hline circular rows & 1 & 1 & - & 1 & - & - & 3 \\
\hline fingernail rows & 2 & 8 & 3 & 4 & 4 & 1 & 22 \\
\hline fingernail row under lip & 1 & - & - & - & - & - & 1 \\
\hline fingernail row, vertical & - & 1 & - & - & - & - & 1 \\
\hline tool rows & 2 & 2 & - & 1 & - & 1 & 6 \\
\hline Subtotal & 6 & 13 & 3 & 6 & 4 & 2 & 34 \\
\hline Totals & 29 & 44 & 5 & 12 & 7 & 14 & 111 \\
\hline
\end{tabular}

L=left; R=right

The appliqued sherds (see Table 18) are likely from the rim and body of both grog-bone and shelltempered varieties of Nash Neck Banded. The appliqued elements occur on both the rim and the vessel body, usually as vertical rows of ridges or fillets as well as sets of four appliqued nodes encircling the vessel rim (see Suhm and Jelks 1962:111). Neck banded rim and body sherds comprise almost 19 percent of the utility 
wares in the NMNH collections, divided between grog- (48 percent of the neck banded sherds), bone- ( 9.5 percent), and shell-tempered (43 percent) wares (see Table 18).

The appliqued-punctated sherd is from a different type than Nash Neck Banded, perhaps an Emory Punctated-Incised jar. In this case, the rim of the vessel has rows of tool punctates and the vessel body is divided into undecorated panels by vertical appliqued fillets.

The brushed and corn cob impressed sherds account for only 2.7 percent of the utility wares in the NMNH collections from the Sanders site. It is likely that these sherds are from Titus phase trade vessels, from a Caddo group living in the upper Sabine River basin, as utility ware jars with these decorative elements (i.e., Bullard Brushed and Anglin Corn Cob Impressed) were regularly manufactured in that part of East Texas. However, brushing is noted on Historic Caddo Emory Punctated-Incised vessels from East Texas (Story et al. 1967:137). These wares are probably associated with the latest Caddo occupation at the Sanders site.

Incised sherds comprise 26 percent of the utility wares, and incised sherds are the most common utility ware in these collections (see Table 18). With the exception of one shell-tempered incised sherd (probably from an Emory Punctated-Incised vessel, see Story et al. 1967:137), the other sherds with incised decorations in the NMNH collections are from grog- and bone-tempered vessels (see Table 18). These are primarily from Canton Incised vessels, primarily jars (see Suhm and Jelks 1962:Plate 12), with diagonal and cross-hatched incised lines on the rim. Rims with horizontal and horizontal-diagonal incised decorative elements may be from both Davis Incised and Dunkin Incised vessels (see Suhm and Jelks 1962:Plates 18 and 19).

The few incised-punctated sherds (4.5 percent of the utility wares in the NMNH collections) from the Sanders site are stylistically diverse (Figure 35a-e; see also Table 18). They include incised triangles filled with tool punctations, from a Canton Incised vessel (see Suhm and Jelks 1962:Plate 12d, h), others with incised panels filled with punctations, or panels filled with diagonal incised lines (Figure 35b-c), and a rim with horizontal and vertical lines and a panel filled with cane punctates (Figure 35e).

The most intriguing incised-punctated sherd in the NMNH collection is a large lower rim sherd from a carinated bowl (see Figure 35d). This rim has sets of near vertical incised lines, with opposed sets of semicircular incised lines with embedded semi-circles and brackets filled with small tool punctations. If this particular vessel is part of the Sanders phase ceramic assemblage at the site, it may well be a late variety of Crockett Curvilinear Incised or Pennington Punctated-Incised.

The different utility ware decorative methods and elements are all represented by sherds from vessels tempered with either grog or bone (see Table 18). However, among the shell-tempered utility wares, known to be among the latest ceramics made and used at the site, the decorative elements only include appliqued (28.6 percent of the appliqued sherds), incised (3.4 percent), neck banded (42.9 percent), fingernail punctated (20.8 percent), and tool punctated (16.7 percent) elements.

About 59 percent of the decorated sherds in the NMNH collections from the Sanders site are from fine wares (see Table 17); this proportion is not much different from the other analyzed collections from the site. The fine wares are dominated by sherds with engraved designs ( 62 percent), followed by sherds with red-slipped surfaces (31 percent), and sherds with trailed designs (7 percent) (Table 19).

There are a number of grog- and bone-tempered engraved sherds in the NMNH collections from the Sanders site (see Table 19), but few that can be confidently identified as Sanders Engraved (see Suhm and Jelks 1962:Plate 69) in the assemblage. There is one lower rim sherd with a large hatched triangle element (Figure 36e) that is stylistically concordant with known examples of Sanders Engraved (Suhm and Jelks 1962:Plate 69a, i), but others have hatched brackets (Figure 36a, c), diagonal hatched zones (Figure 36k), horizontal and curvilinear lines (Figure 36b), small open triangles (Figure 36d), circles (Figure 36f, l) and circular elements (Figure 36g, j), as well as excised pendant triangles (Figure 36h-i). 


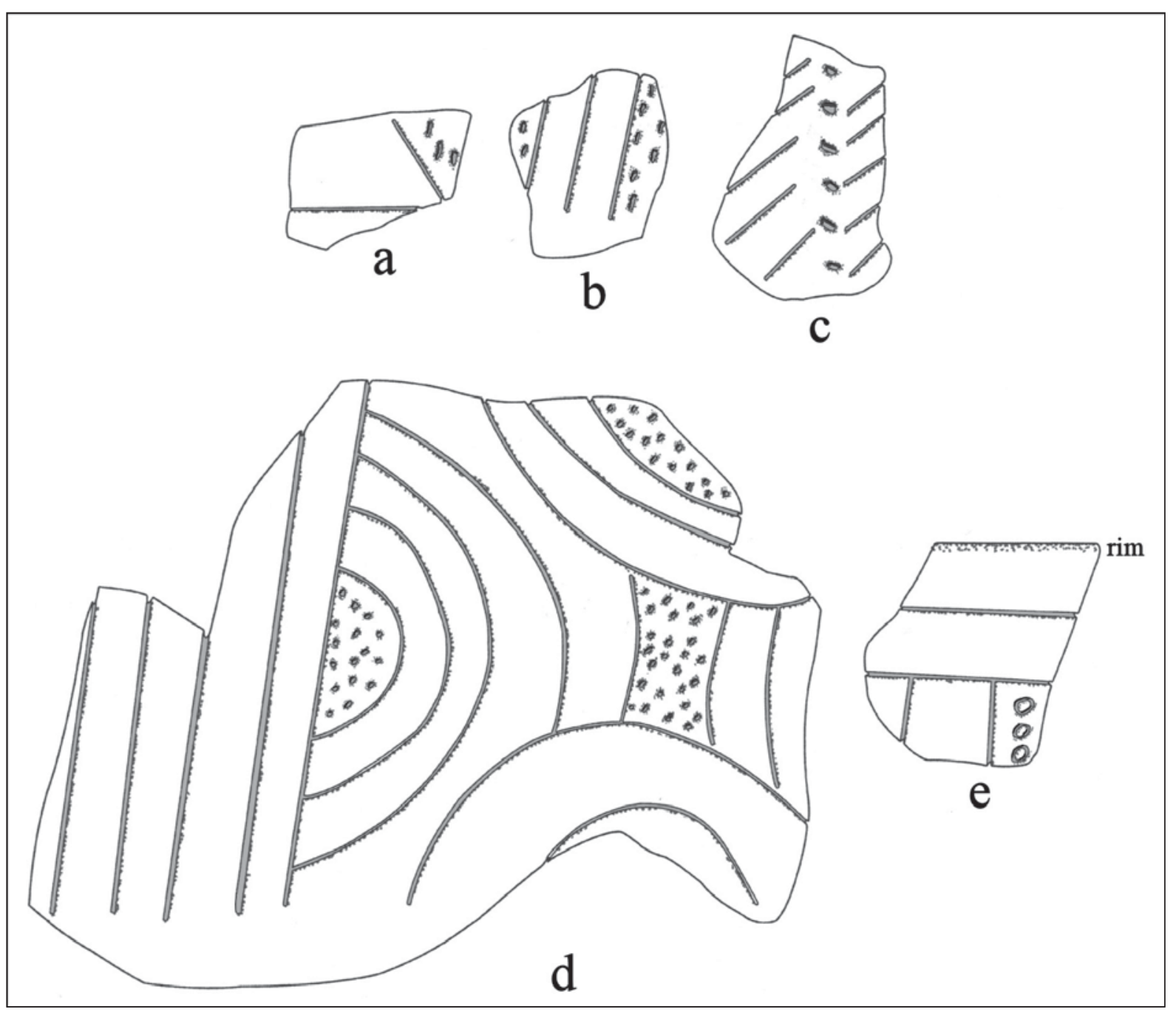

Figure 35. Incised-punctated rim and body sherds from the Sanders site in the NMNH collections.

Grog- and bone-tempered sherds with engraved scroll elements-previously dubbed Bois d'Arc Engraved (see above) - comprise almost 16 percent of the engraved fine wares in the NMNH collections (see Table 19). These sherds are from carinated bowls with slanted scrolls that typically have a slanted scroll central line (one rim has a ticked central scroll line [Figure 37b] and may be stylistically related to Womack Engraved, see below), but a variety of upper and lower scroll fill zones (Figure 37a-k). The scroll fill zones are filled with curvilinear lines, vertical lines, near vertical hatched zones, and cross-hatched zones and brackets.

The most common fine ware sherds in the NMNH collections from the Sanders site are from Womack Engraved carinated bowls with inverted rims (see Table 19). Regardless of temper, they comprise almost 21 percent of all the engraved fine ware sherds and 20 percent of all the engraved rim sherds. Ninety-five percent of the Womack Engraved sherds in this collection are from grog- and bone-tempered vessels.

The most common Womack Engraved stylistic elements at the Sanders site are part of meandering or slanted scrolls with excised tick marks on the central scroll lines (Figure 38c, g, k-l; see also Story et al. 1967:Figure 49b, d). Other scrolls end in hooked arms, but have no tick marks on the central scroll line (Figure 38f, i). Scroll fill zones include cross-hatched brackets (Figure 38a-b, k), zones (Figure 38d), triangular elements (Figure 38h-j), and cross-hatched brackets with negative ovals (Figure 381; see Story et al. 1967:Figure 49b). 
Table 19. Decorative elements in the fine ware sherds from the Sanders site in the NMNH collection.

\begin{tabular}{|c|c|c|c|c|c|c|c|}
\hline \multirow[b]{2}{*}{ Decorative element } & \multicolumn{2}{|c|}{ grog } & \multicolumn{2}{|c|}{ bone } & \multicolumn{2}{|c|}{ shell } & \multirow[b]{2}{*}{$\mathrm{N}$} \\
\hline & rim & body & rim & body & rim & body & \\
\hline \multicolumn{8}{|l|}{ Engraved } \\
\hline concentric circles & - & - & - & 1 & - & - & 1 \\
\hline cross-hatched bracket & - & 2 & - & - & - & - & 2 \\
\hline cross-hatched zone & - & 1 & - & - & - & - & 1 \\
\hline $\begin{array}{l}\text { cross-hatched zone, } \\
\text { horizontal line, and } \\
\text { vertical line with tick } \\
\text { marks }\end{array}$ & - & - & - & - & 1 & - & 1 \\
\hline curvilinear lines & - & 1 & - & 1 & - & 1 & 3 \\
\hline curvilinear hatched zone & - & - & - & 2 & - & - & 2 \\
\hline $\begin{array}{l}\text { curvilinear cross-hatched } \\
\text { zone }\end{array}$ & - & - & - & - & - & 1 & 1 \\
\hline hatched brackets & 1 & - & - & - & - & - & 1 \\
\hline hatched zone & - & 4 & - & - & 1 & - & 5 \\
\hline hatched zones, slanted & - & 1 & - & - & - & - & 1 \\
\hline hatched zone in panel & - & 1 & - & 1 & - & - & 2 \\
\hline hatched triangle & - & 1 & - & - & - & 1 & 2 \\
\hline horizontal lines & 3 & 2 & - & - & - & - & 5 \\
\hline $\begin{array}{l}\text { horizontal and curvilinear } \\
\text { lines }\end{array}$ & 3 & 1 & - & - & - & - & 4 \\
\hline $\begin{array}{l}\text { horizontal and curvilinear } \\
\text { lines and hatched circle } \\
\text { element }\end{array}$ & - & 1 & - & - & - & - & 1 \\
\hline $\begin{array}{l}\text { horizontal and curvilinear } \\
\text { lines and hatched bracket }\end{array}$ & 1 & - & - & - & - & - & 1 \\
\hline $\begin{array}{l}\text { horizontal and diagonal } \\
\text { lines }\end{array}$ & 2 & 1 & - & - & - & - & 3 \\
\hline $\begin{array}{l}\text { horizontal and diagonal } \\
\text { lines and vertical line } \\
\text { with open pendant } \\
\text { triangles }\end{array}$ & 1 & - & - & - & - & - & 1 \\
\hline $\begin{array}{l}\text { horizontal lines and excised } \\
\text { pendant triangle }\end{array}$ & - & - & - & - & 1 & - & 1 \\
\hline $\begin{array}{l}\text { horizontal and vertical } \\
\text { lines and excised } \\
\text { pendant triangles }\end{array}$ & 1 & - & - & - & - & - & 1 \\
\hline $\begin{array}{l}\text { horizontal and vertical } \\
\text { lines and circle el. }\end{array}$ & 1 & - & - & - & - & - & 1 \\
\hline $\begin{array}{l}\text { horizontal panel with } \\
\text { excised bracket and } \\
\text { small excised triangles }\end{array}$ & - & 1 & - & - & - & - & 1 \\
\hline
\end{tabular}


Table 19. Decorative elements in the fine ware sherds from the Sanders site in the NMNH collection, cont.

\begin{tabular}{|c|c|c|c|c|c|c|c|}
\hline \multirow[b]{2}{*}{ Decorative element } & \multicolumn{2}{|c|}{ grog } & \multicolumn{2}{|c|}{ bone } & \multicolumn{2}{|c|}{ shell } & \multirow[b]{2}{*}{$\mathrm{N}$} \\
\hline & rim & body & rim & body & rim & body & \\
\hline opposed lines & - & 1 & - & - & - & - & 1 \\
\hline parallel lines & - & 3 & - & - & - & - & 3 \\
\hline $\begin{array}{l}\text { parallel and curvilinear } \\
\text { lines }\end{array}$ & - & 1 & - & - & - & - & 1 \\
\hline $\begin{array}{l}\text { parallel and diagonal } \\
\text { opposed lines }\end{array}$ & - & 1 & - & - & - & - & 1 \\
\hline $\begin{array}{l}\text { slanted scroll element } \\
\text { with curvilinear lines } \\
\text { in scroll fill zone }\end{array}$ & 1 & - & - & 1 & 1 & - & 3 \\
\hline $\begin{array}{l}\text { slanted scroll and hatched } \\
\text { brackets in fill zones }\end{array}$ & - & 2 & - & - & - & - & 2 \\
\hline $\begin{array}{l}\text { slanted scroll element } \\
\text { with cross-hatched } \\
\text { bracket in fill zone }\end{array}$ & 4 & - & - & - & - & - & 4 \\
\hline $\begin{array}{l}\text { slanted scroll element, } \\
\text { tick marks on scroll line, } \\
\text { and sets of vertical lines } \\
\text { in fill zone }\end{array}$ & 1 & - & - & - & - & - & 1 \\
\hline $\begin{array}{l}\text { scroll element and cross- } \\
\text { hatched bracket }\end{array}$ & - & 1 & - & - & - & - & 1 \\
\hline $\begin{array}{l}\text { scroll element with } \\
\text { vertical hatched } \\
\text { triangle zone }\end{array}$ & 1 & - & - & - & - & - & 1 \\
\hline $\begin{array}{l}\text { scroll fill zone with } \\
\text { curvilinear lines }\end{array}$ & 3 & 1 & - & - & - & - & 4 \\
\hline Subtotal & 10 & 4 & - & 1 & 1 & - & 16 \\
\hline straight lines & - & 3 & - & 1 & - & - & 4 \\
\hline $\begin{array}{l}\text { straight line and } \\
\text { excised triangle }\end{array}$ & - & - & - & - & - & 1 & 1 \\
\hline $\begin{array}{l}\text { vertical lines and } \\
\text { circle element }\end{array}$ & - & - & - & 1 & - & - & 1 \\
\hline
\end{tabular}

\section{Hudson Engraved}

engraved zones filled

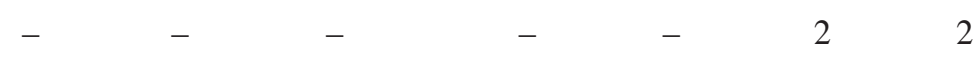

with parallel incised

lines

\section{Simms Engraved}

horizontal line with tick marks 
Table 19. Decorative elements in the fine ware sherds from the Sanders site in the NMNH collection, cont.

\begin{tabular}{|c|c|c|c|c|c|c|c|}
\hline \multirow[b]{2}{*}{ Decorative element } & \multicolumn{2}{|c|}{ grog } & \multicolumn{2}{|c|}{ bone } & \multicolumn{2}{|c|}{ shell } & \multirow[b]{2}{*}{$\mathrm{N}$} \\
\hline & rim & body & rim & body & rim & body & \\
\hline $\begin{array}{l}\text { horizontal line with tick } \\
\text { marks and hatched } \\
\text { triangle element }\end{array}$ & - & - & - & - & - & 1 & 1 \\
\hline $\begin{array}{l}\text { horizontal and vertical } \\
\text { lines and small excised } \\
\text { dots }\end{array}$ & - & - & - & - & 1 & - & 1 \\
\hline $\begin{array}{l}\text { straight line with tick } \\
\text { marks }\end{array}$ & - & - & - & - & - & 1 & 1 \\
\hline Subtotal & - & - & - & - & 2 & 3 & 5 \\
\hline \multicolumn{8}{|l|}{ Womack Engraved } \\
\hline $\begin{array}{l}\text { circle element and cross- } \\
\text { hatched zone }\end{array}$ & - & 2 & - & - & - & - & 2 \\
\hline $\begin{array}{l}\text { curvilinear line with } \\
\text { tick marks }\end{array}$ & - & 1 & - & - & - & - & 1 \\
\hline $\begin{array}{l}\text { curvilinear line with tick } \\
\text { marks and cross- } \\
\text { hatched bracket }\end{array}$ & - & 2 & - & - & - & - & 2 \\
\hline $\begin{array}{l}\text { diagonal lines and curvi- } \\
\text { linear line with tick marks }\end{array}$ & - & 1 & - & - & - & - & 1 \\
\hline $\begin{array}{l}\text { hooked arm element and } \\
\text { curvilinear fill zone }\end{array}$ & - & 1 & - & - & - & 1 & 2 \\
\hline $\begin{array}{l}\text { horizontal line and cross- } \\
\text { hatched bracket }\end{array}$ & 1 & 1 & - & - & - & - & 2 \\
\hline $\begin{array}{l}\text { horizontal lines with } \\
\text { tick marks }\end{array}$ & - & 2 & - & - & - & - & 2 \\
\hline $\begin{array}{l}\text { horizontal line with tick } \\
\text { marks, cross-hatched } \\
\text { brackets and negative } \\
\text { ovals }\end{array}$ & - & 1 & - & - & - & - & 1 \\
\hline $\begin{array}{l}\text { horizontal and curvilinear } \\
\text { lines and cross-hatched } \\
\text { bracket }\end{array}$ & 2 & - & - & - & - & - & 2 \\
\hline $\begin{array}{l}\text { horizontal and diagonal } \\
\text { lines and horizontal } \\
\text { line with tick marks }\end{array}$ & - & 1 & - & - & - & - & 1 \\
\hline $\begin{array}{l}\text { horizontal and vertical lines } \\
\text { and horizontal line with } \\
\text { tick marks }\end{array}$ & 1 & - & - & - & - & - & 1 \\
\hline $\begin{array}{l}\text { horizontal scroll, hooked } \\
\text { arm el., and vertical fill zones }\end{array}$ & 1 & - & - & - & - & - & 1 \\
\hline $\begin{array}{l}\text { slanted scroll, hooked arm } \\
\text { el., and cross-hatched } \\
\text { fill zone }\end{array}$ & 1 & - & - & - & - & - & 1 \\
\hline
\end{tabular}


Table 19. Decorative elements in the fine ware sherds from the Sanders site in the NMNH collection, cont.

\begin{tabular}{|c|c|c|c|c|c|c|c|}
\hline \multirow[b]{2}{*}{ Decorative element } & \multicolumn{2}{|c|}{ grog } & \multicolumn{2}{|c|}{ bone } & \multicolumn{2}{|c|}{ shell } & \multirow[b]{2}{*}{$\mathrm{N}$} \\
\hline & rim & body & rim & body & rim & body & \\
\hline $\begin{array}{l}\text { slanted scroll with tick } \\
\text { marks and curvilinear } \\
\text { fill zone }\end{array}$ & 1 & - & - & - & - & - & 1 \\
\hline Subtotal & 7 & 12 & - & - & - & 1 & 20 \\
\hline \multicolumn{8}{|l|}{ Red-slipped } \\
\hline ext. red-slipped & 1 & 5 & - & 3 & - & 1 & 10 \\
\hline int. red-slipped & - & 1 & - & - & - & - & 1 \\
\hline int./ext. red-slipped & 6 & 16 & 2 & 6 & 1 & 5 & 36 \\
\hline Subtotal & 7 & 22 & 2 & 9 & 1 & 6 & 47 \\
\hline \multicolumn{8}{|l|}{ Trailed } \\
\hline curvilinear lines & - & 3 & - & - & - & 4 & 7 \\
\hline $\begin{array}{l}\text { curvilinear and hooked } \\
\text { arms }\end{array}$ & - & - & - & - & - & 1 & 1 \\
\hline curvilinear opposed lines & - & - & - & - & - & 1 & 1 \\
\hline parallel lines & - & 2 & - & - & - & - & 2 \\
\hline Subtotal & - & 5 & - & - & - & 6 & 11 \\
\hline Totals & 37 & 69 & 2 & 17 & 7 & 22 & 154 \\
\hline
\end{tabular}

Although not abundant (7 percent of the engraved sherds), the principal shell-tempered engraved fine wares in the NMNH collections are Hudson Engraved and Simms Engraved (see Table 19); only 5 percent of the Womack Engraved sherds are shell-tempered. The Simms Engraved sherds have short inverted rims with horizontal tick-marked lines and panels with a row of excised punctates (Figure 39a-d).

The other shell-tempered engraved fine wares ( $n=8$ sherds) in the NMNH collections from the Sanders site have a variety of decorative elements; none can be identified to a defined fine ware type. They include horizontal lines with pendant excised triangles (Figure 40b-c), concentric curvilinear lines (Figure 40a), a slanted scroll (Figure 40g), a rim with a diagonal hatched zone (Figure 40e), and sherds with curvilinear cross-hatched and hatched zones (Figure 40d,f). One rim also has a vertical engraved line with excised tick marks (Figure 40f).

About 85 percent of the red-slipped sherds (from bottles and bowls) are from grog- and bone-tempered Sanders Plain vessels, or the undecorated portions of Maxey Noded Redware vessels (see Table 19). The remaining 15 percent are from shell-tempered Clement Redware vessels or the undecorated portions of redslipped shell-tempered engraved vessels (i.e., Avery Engraved).

Sherds from Keno Trailed vessels decorated with trailed lines comprise 7.1 percent of the fine wares in the NMNH collections from the Sanders site (see Table 19). These vessels have sets of curvilinear and curvilinear opposed trailed lines, sometimes ending in sets of hooked arms (Figure 41a-d). 


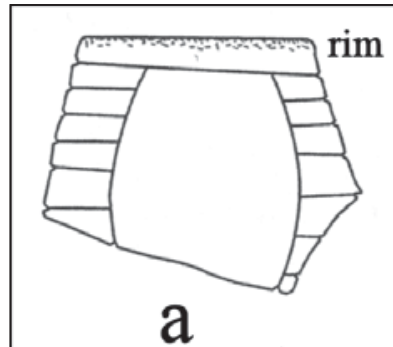

a
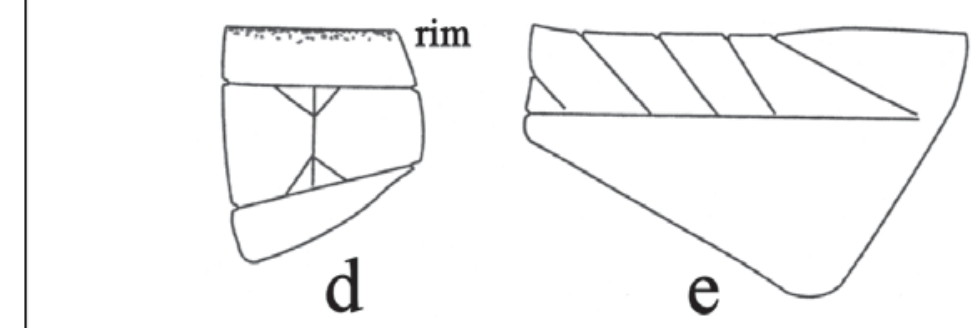

b
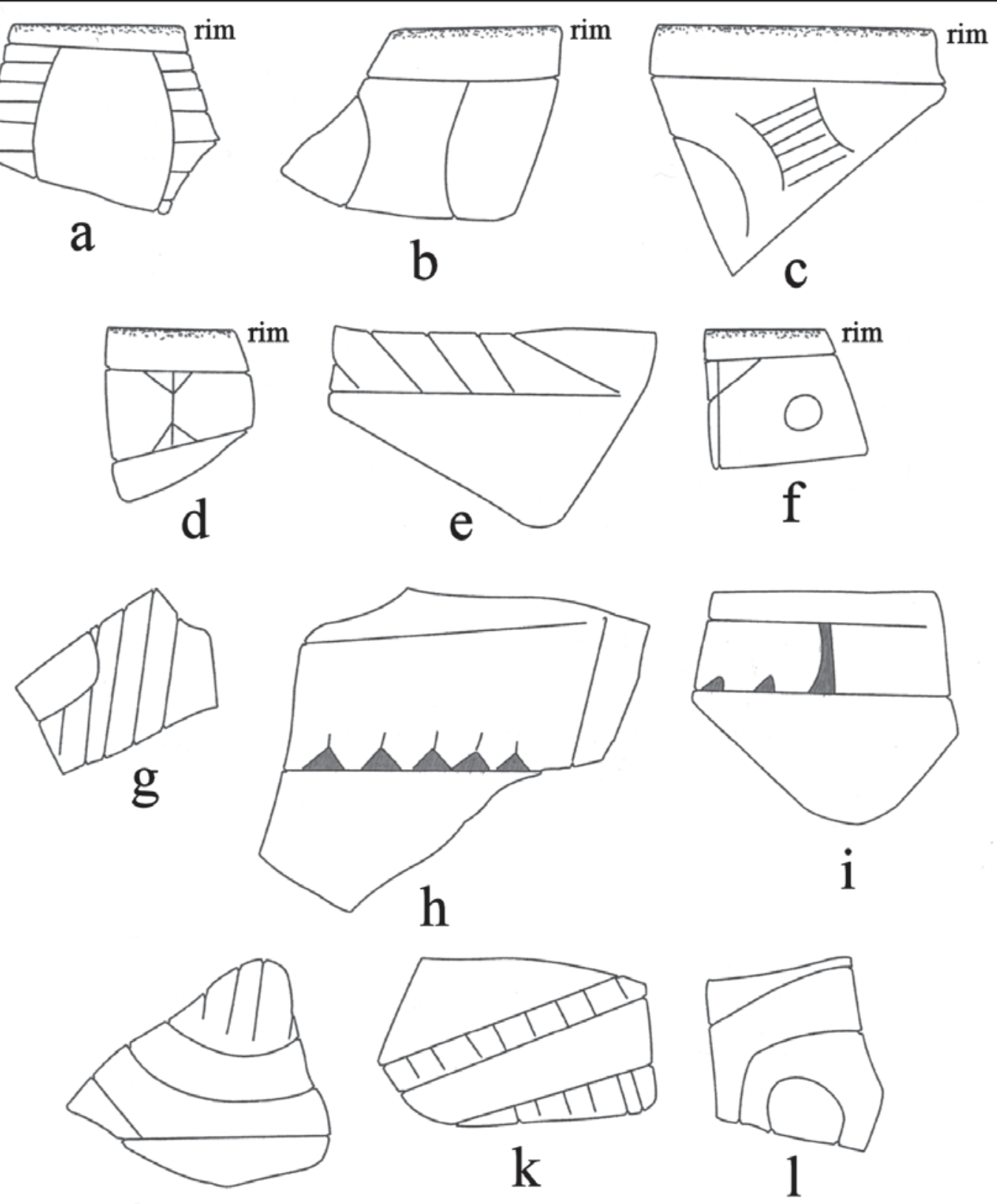

$\mathrm{j}$
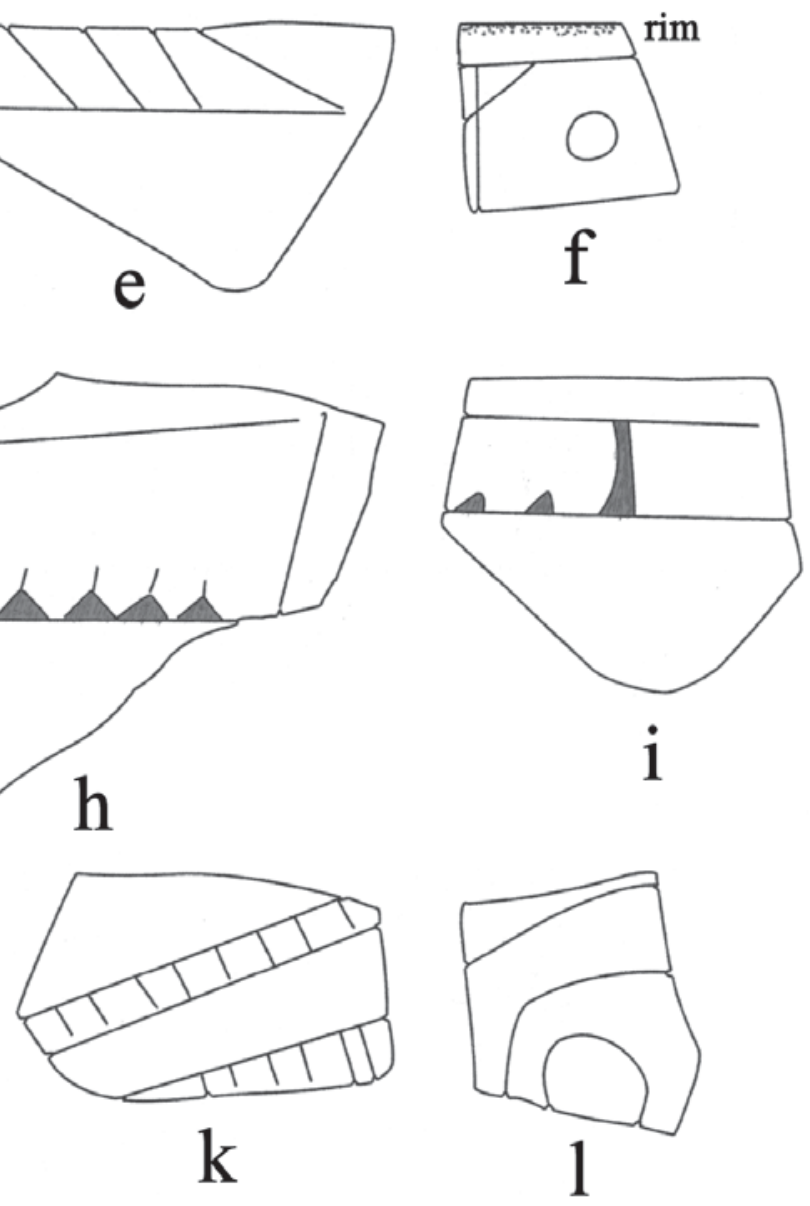

Figure 36. Decorative elements on selected grog- and bone-tempered engraved sherds in the NMNH collections from the Sanders site. 

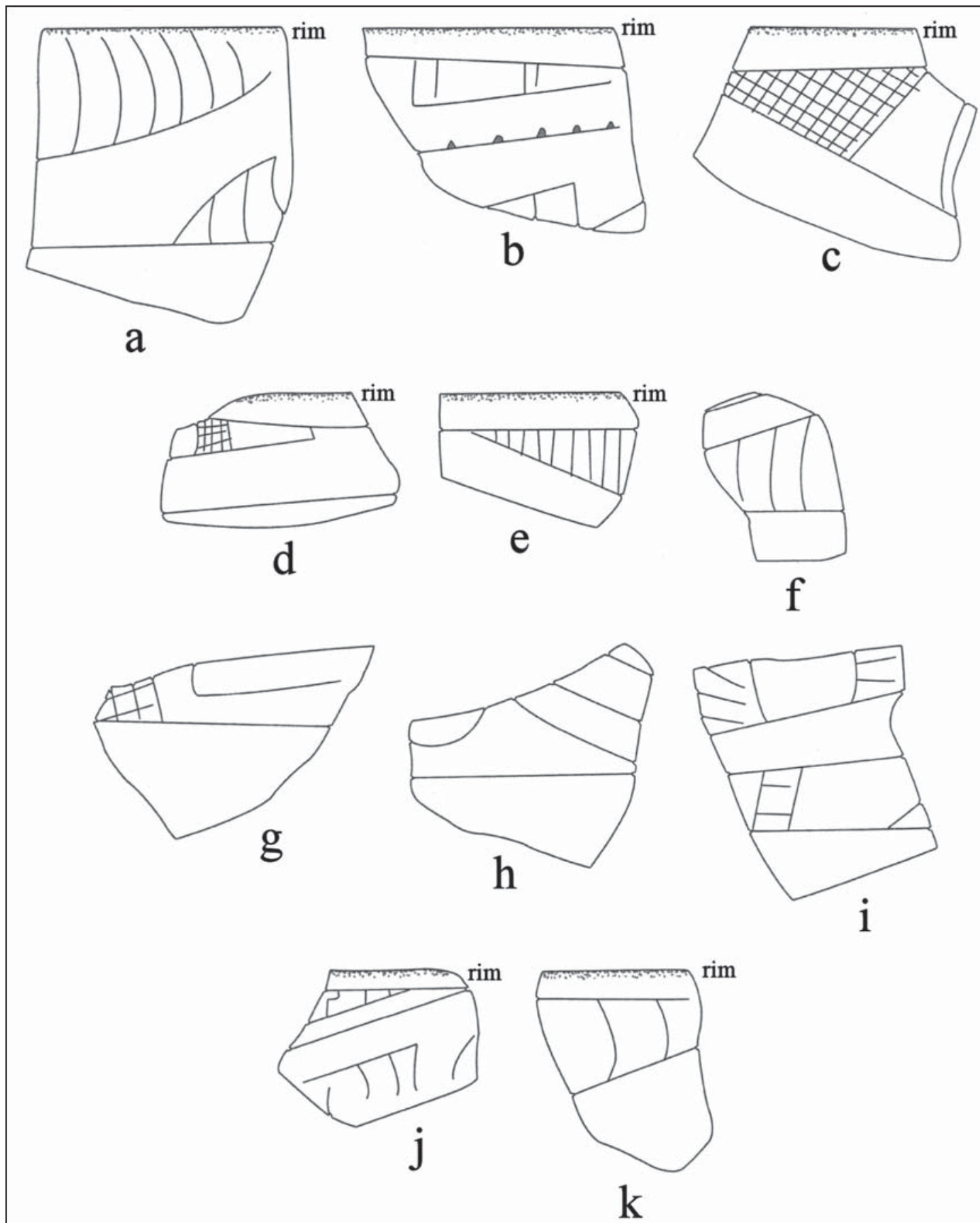

Figure 37. Decorative elements on engraved sherds with scroll elements (i.e., Bois d'Arc Engraved) in the NMNH collections from the Sanders site. 


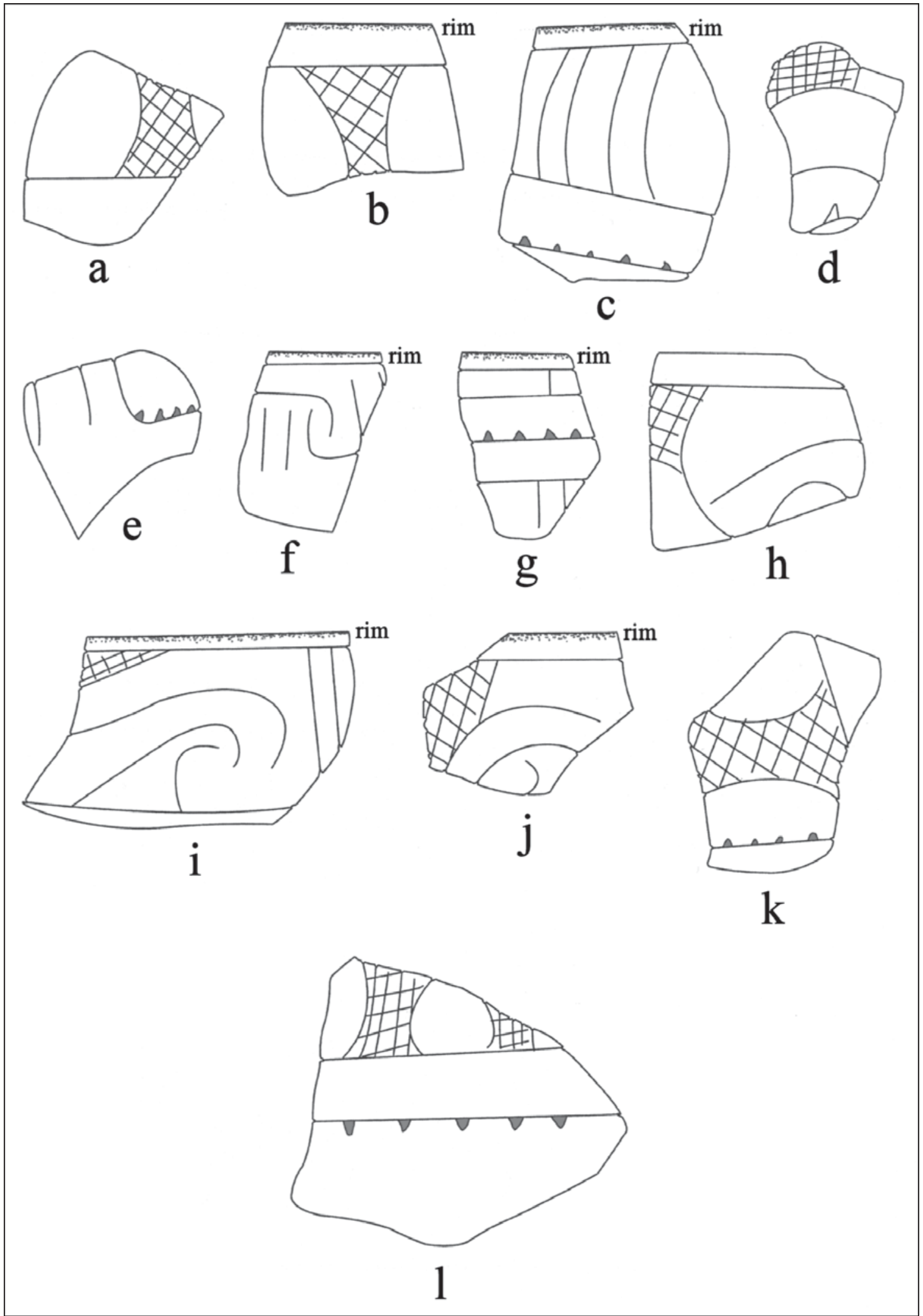

Figure 38. Decorative elements on Womack Engraved sherds in the NMNH collections from the Sanders site. 


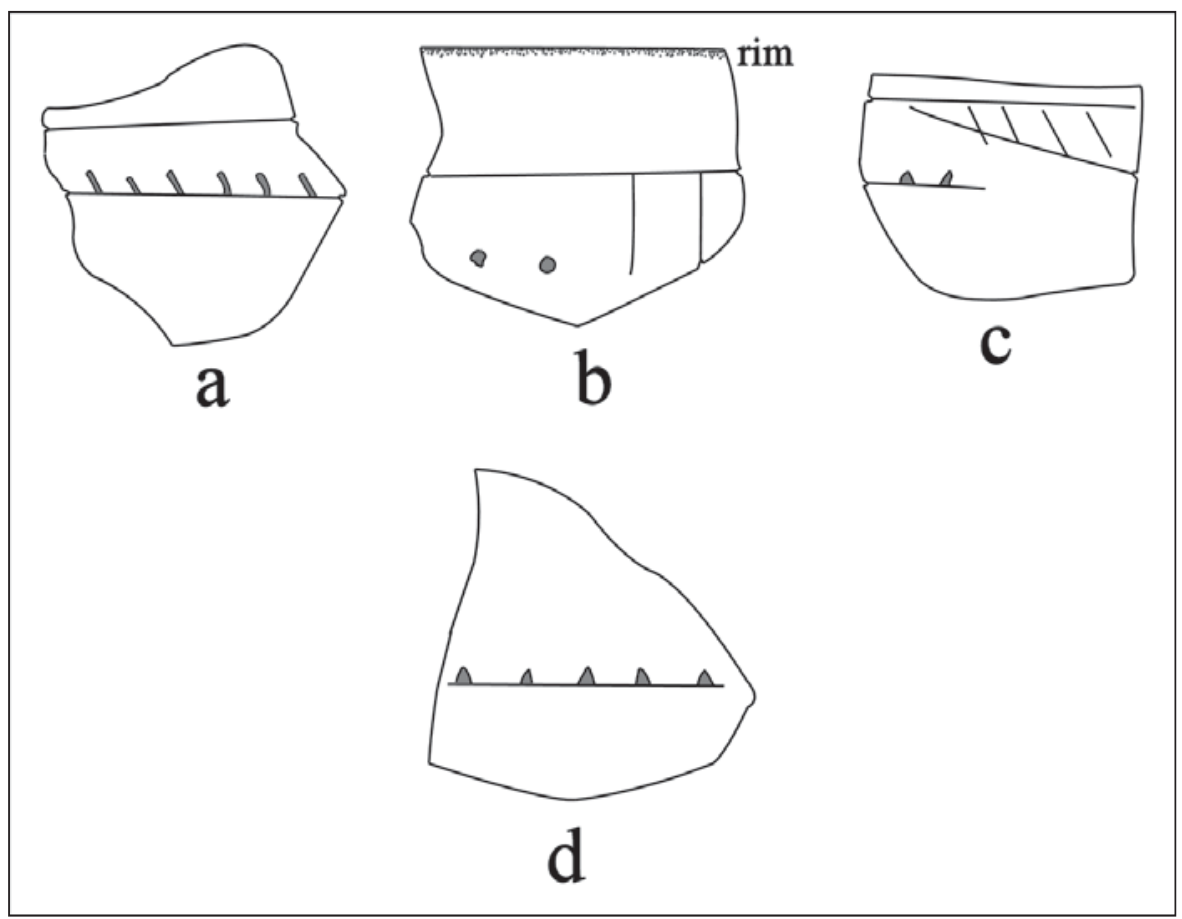

Figure 39. Decorative elements on Simms Engraved sherds in the NMNH collections from the Sanders site.

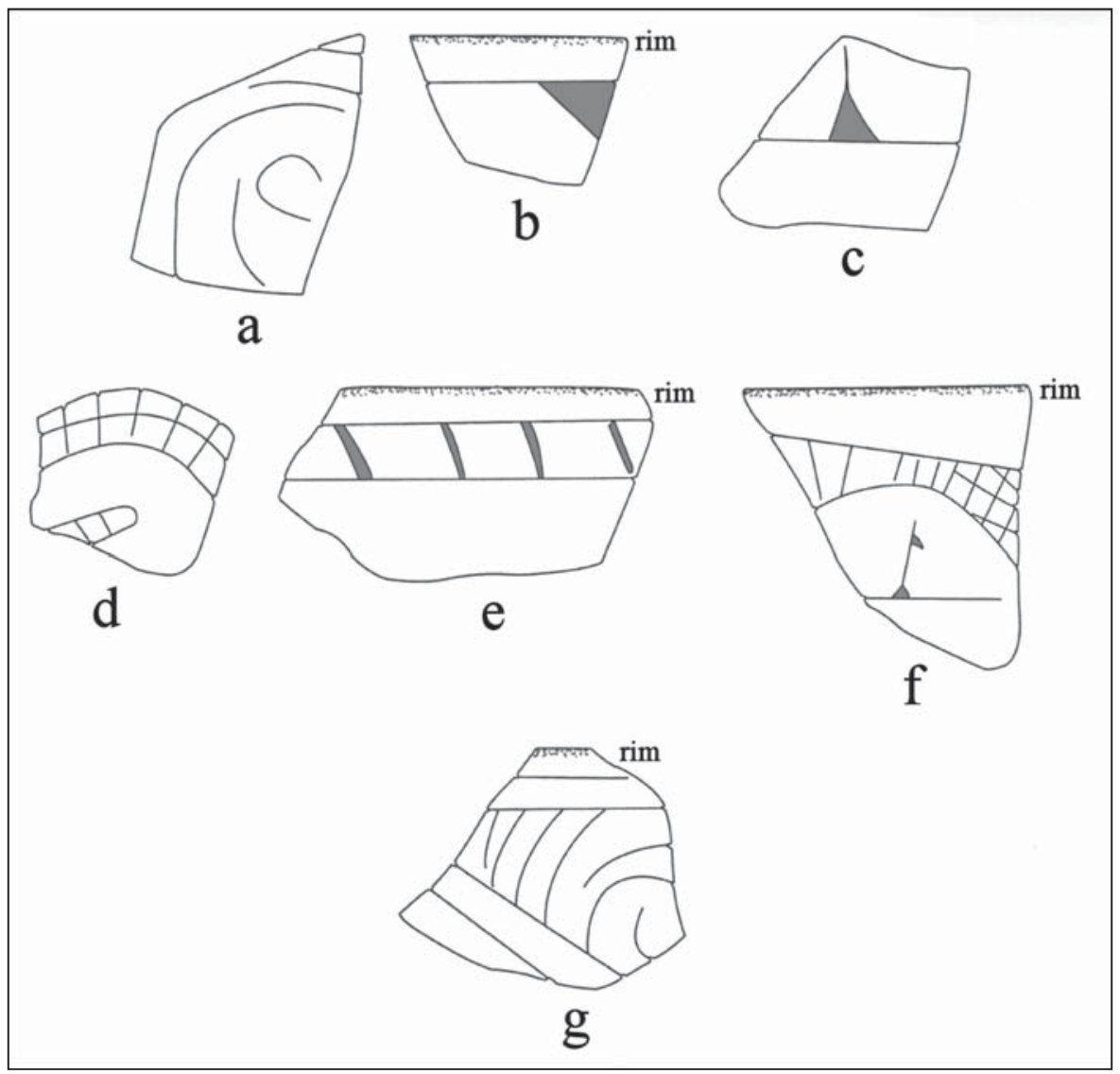

Figure 40. Decorative elements on shell-tempered fine ware sherds in the NMNH collections from the Sanders site. 


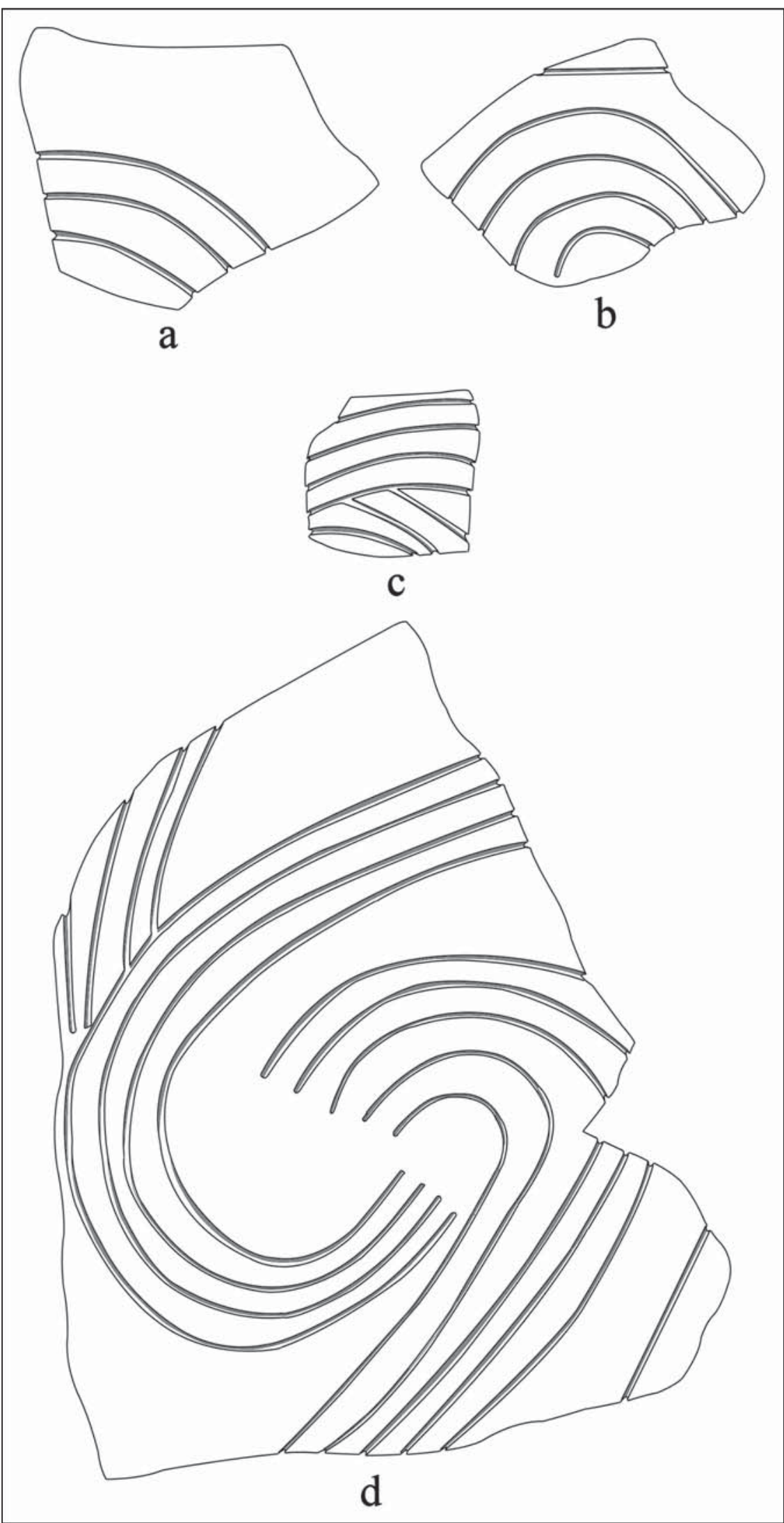

Figure 41. Decorative elements on trailed sherds from the Sanders site in the NMNH collections. 
The different fine ware decorative methods and elements are all represented by sherds from vessels tempered with either grog or bone (see Table 19). About 69.2 percent of the fine wares are from grogtempered vessels, 12.2 percent of the fine wares are from bone-tempered vessels, and 18.6 percent of the fine ware sherds are from shell-tempered vessels. Only the trailed sherds are most common among the shelltempered fine wares (i.e., 54.5 percent of the trailed sherds are from shell-tempered vessels), while sherds from red-slipped sherds are quite commonly from bone-tempered vessels (23.4 percent of the red-slipped sherds are from bone-tempered vessels).

\section{Ceramic Pipes and Pipe Sherds}

Ceramic pipe sherds are relatively common in the Sanders site assemblage. There are both long-stemmed and bone-tempered Red River pipe sherds (11 pipe stems) as well as complete elbow pipes and pipe sherds. The Red River style pipe sherds are from both bone-tempered 64 percent) and grog-tempered (36 percent) pipes. Two pipe sherds are from the butt end of var. Haley Red River styles pipes (see Hoffman 1967). The pipe stem sherds range from 6.3-14.0 $\mathrm{mm}$ in exterior diameter.

There is one large rim and body sherd from a grog-tempered elbow pipe that is decorated with a crosshatched engraved zone on the bowl itself (Figure 42a). Another elbow pipe, bone-tempered, is undecorated; it is $41 \mathrm{~mm}$ in height, has a $38 \mathrm{~mm}$ bowl orifice diameter, and a $33 \mathrm{~mm}$ stem diameter (Figure 42b). A smaller elbow pipe (Figure 42c) has four cross-hatched engraved triangles on the bowl; the pipe is $29 \mathrm{~mm}$ in height, has a $27 \mathrm{~mm}$ bowl orifice diameter, and a $12.5 \mathrm{~mm}$ stem diameter.

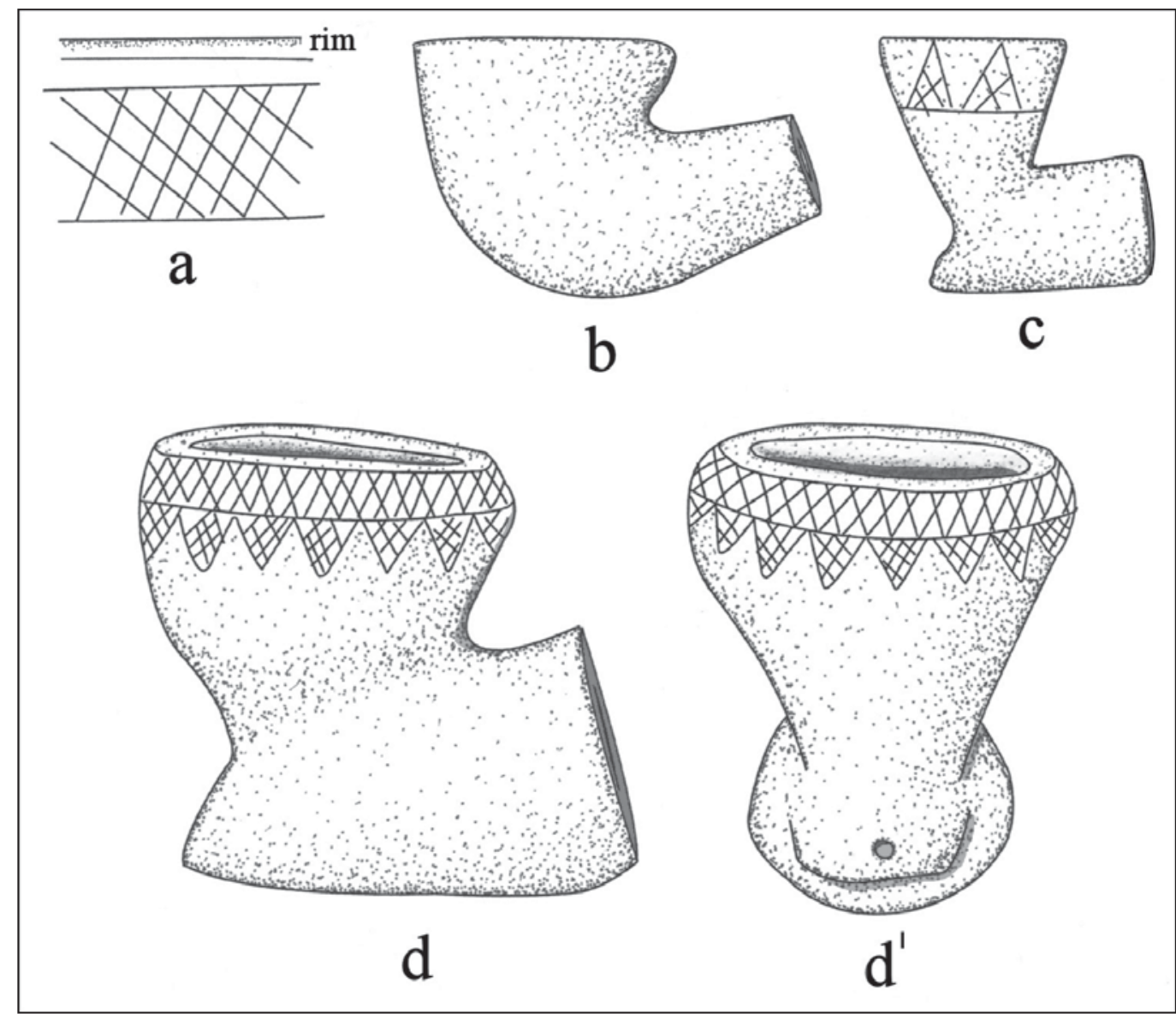

Figure 42. Elbow pipes from the Sanders site NMNH collections: a, c, engraved elbow pipes; b, plain elbow pipe; d-d', engraved elbow pipe (after Harris 1953:20). 
Another elbow pipe (A513196), found south of the mounds at Sanders in an area with glass beads, triangular arrow points, and other evidence of an Historic Caddo settlement, is decorated on the upper part of the bowl (see Figure 42d-d') with engraved elements. The upper part of the decoration is a narrow zone of cross-hatched engraved lines; pendant from the bottom of this zone are a series of cross-hatched engraved triangles whose apexes point towards the pipe stem. The pipe is $47.9 \mathrm{~mm}$ in height, with a $41.9 \mathrm{~mm}$ bowl orifice diameter, and a $27.0 \mathrm{~mm}$ stem diameter. On the front of the stem, below the bowl, is a small drilled hole (see Figure 42d'); the hole may have been used as an attachment for "feathers or other forms of decoration" (Harris 1953:20).

\section{Stone Pipe Sherds}

One of these pipe sherds is an undecorated reddish-brown bowl fragment of Mississippi Valley fired clay material (see Emerson and Hughes 2000; Emerson et al. 2003). The other is a light gray siltstone elbow pipe sherd with a $27.0 \mathrm{~mm}$ bowl orifice diameter. These are probably from L-shaped stone pipes similar to those found in burials at the Sanders site (see Jackson et al. 2000:53).

\section{Catlinite Pipe Sherd}

A small piece of the rim of a Catlinite pipe bowl $(7.3 \mathrm{~mm}$ in thickness) is in the NMNH collections from the Sanders site. It has a single deep horizontal line engraved under the bowl lip. This pipe is evidence that the Caddo peoples who lived at the Sanders site in the late 17th-early 18th century participated in calumet ceremonialism (e.g., Rodning 2014) during a time of early European colonialism in the Caddo area. The Catlinite pipe fragment from the Sanders site may be the farthest west of such pipes in eastern North America (see Rodning 2014:Figure 1).

\section{Chipped Stone Tools}

The large assemblage of chipped stone tools in the NMNH collections from the Sanders site include dart points $(n=49)$, arrow points $(n=380)$ and arrow point preforms $(n=4)$, bifacial knives and large blades $(n=3)$, beveled knives $(n=5)$, bi-pointed knives $(n=3)$, scrapers $(n=72)$, one adze, drills/perforators $(n=3)$ and bi-pointed drills $(n=5)$, and a single flake tools (made from a local red chert). The majority of these chipped stone tools are made from local cherts from Red River cherts; the original source of these cherts is in the Ouachita Mountains of Southeast Oklahoma.

The dart points from the Sanders site are dominated by Woodland period (ca. 500 B.C.-A.D. 700) Gary points (Table 20), along with other point types that appear to also date to the earlier part of the Woodland period (i.e., Darl, Kent, and Trinity); the calibrated age range of Darl dart points is 1350-1150 B.P. (Lohse et al. 2014). There are only three dart points that may be Late Archaic forms in this dart point assemblage (i.e., Carrollton, Morrill, and an unidentified corner-notched form).

More than 77 percent of the dart points in the NMNH Sanders site collection are manufactured from high-quality Ouachita Mountains cherts (see Table 20); these materials would have been available in local

Red River gravels, along with novaculite. Novaculite was used in the manufacture of only 8 percent of the dart points from the Sanders site; a similar amount of the arrow points were made from local quartzite.

More than 71 percent of the arrow points from the Sanders site in the NMNH collections are triangular Maud or Fresno arrow points (Table 21). These are likely part of the extensive late 17th-early 18th century occupation at the Sanders site. Other associated arrow points in this component include the Cuney and Washita types. Together, these three arrow point types comprise 81 percent of the typologically identifiable points in the NMNH assemblage. These points are made from high-quality Ouachita Mountains cherts (84 percent), novaculite (14 percent), and quartzite ( 2 percent). 
Table 20. Dart points from the Sanders site in the NMNH collections.

\begin{tabular}{|c|c|c|c|c|c|}
\hline Type & NOV & QTZ & $\begin{array}{l}\text { Material } \\
\text { OM cherts }\end{array}$ & gravel chert & $\mathrm{N}$ \\
\hline Carrollton & - & - & 1 & - & 1 \\
\hline Darl & - & - & 2 & - & 2 \\
\hline Gary & 2 & 2 & 20 & 3 & 27 \\
\hline Kent & - & - & 2 & - & 2 \\
\hline Morrill & - & - & 1 & - & 1 \\
\hline Trinity & - & - & 1 & - & 1 \\
\hline $\begin{array}{l}\text { UID corner- } \\
\text { notched and } \\
\text { rounded base }\end{array}$ & - & 1 & - & - & 1 \\
\hline $\begin{array}{l}\text { blade and tip } \\
\text { fragments }\end{array}$ & 2 & 1 & 11 & - & 14 \\
\hline Totals & 4 & 4 & 38 & 3 & 49 \\
\hline
\end{tabular}

NOV=novaculite; QTZ=quartzite; OM=Ouachita Mountains; UID=unidentified

Table 21. Arrow points and arrow point preforms from the Sanders site in the NMNH collections.

\begin{tabular}{|c|c|c|c|c|c|}
\hline Type & NOV & QTZ & $\begin{array}{l}\text { Material } \\
\text { OM cherts }\end{array}$ & gravel chert & $\mathrm{N}$ \\
\hline Alba & 1 & 3 & 15 & - & 19 \\
\hline Bonham & 1 & - & 11 & - & 12 \\
\hline Cuney & - & - & 3 & - & 3 \\
\hline Hayes & 2 & - & 12 & - & 14 \\
\hline Homan/Colbert & 2 & - & 3 & - & 5 \\
\hline cf. Keota & - & - & 1 & - & 1 \\
\hline Maud or Fresno+ & 39 & 6 & 227 & - & 274 \\
\hline Scallorn & 2 & - & 11 & 1 & 14 \\
\hline cf. Sequoyah & - & - & 1 & - & 1 \\
\hline Washita & 1 & - & 8 & - & 9 \\
\hline $\begin{array}{l}\text { blade and tip } \\
\text { fragments }\end{array}$ & 1 & 1 & 26 & - & 28 \\
\hline preform & 1 & - & 3 & - & 4 \\
\hline Totals & 50 & 10 & 321 & 1 & 384 \\
\hline
\end{tabular}

$\mathrm{NOV}=$ novaculite; $\mathrm{QTZ}=$ quartzite; $\mathrm{OM}=$ Ouachita Mountains

+also includes two points made from Alibates, possibly obtained in Red River gravels

* gravel cherts include earth-toned colors, red, yellow, brown, and reddish-brown. 
The earliest arrow points in the assemblage, perhaps dating between ca. A.D. 900-1100, include the Alba, Homan/Colbert, and Scallorn types; they comprise 10 percent of the arrow point assemblage. It is also possible, however, that the Scallorn points represent part of a ca. A.D. 700-900 Woodland period use of the Sanders site, since calibrated radiocarbon dates indicate that Scallorn arrow points began to be made at ca. A.D. 700 (see Lohse et al. 2014). With respect to the use of lithic raw materials, these Early Caddo point types were made from Ouachita Mountains chert ( 83 percent), novaculite (14 percent), and local earth-toned chert ( 3 percent). The use of Ouachita Mountains chert and novaculite in the Early Caddo point assemblage is virtually identical to the assemblage of Late-Historic Caddo arrow points (see Table 21).

The remainder of the stemmed arrow points in this Sanders site collection (including Bonham, Hayes, Keota, and Sequoyah types, see Table 21) may be associated with the Middle Caddo Sanders phase occupation, and thus would date from ca. A.D. 1100-1300 (this is the current estimate of the age of the phase, although the Sanders phase is currently not well dated). These points comprise only 8 percent of the typologically identifiable arrow point assemblage from the Sanders site in the NMNH collection. These Middle Caddo point types were made from Ouachita Mountains chert ( 89 percent) and novaculite (11 percent). The use of Ouachita Mountains chert and novaculite in the Middle Caddo point assemblage is comparable to the assemblages of both Early Caddo and Late-Historic Caddo arrow points at the Sanders site (see Table 21).

The large bifacial knives and blades are made from cherts, including Ouachita Mountains chert $(\mathrm{n}=2)$, and a dark gray Central Texas chert $(\mathrm{n}=1)$. This latter large blade is $143 \times 58 \times 11 \mathrm{~mm}$ in length, width, and thickness (Figure 43c). The bifacially worked beveled knives (Figure 43a) are made from local quartzite $(n=2)$, Ouachita Mountains quartzite $(n=1)$, and Ouachita Mountains cherts $(n=2)$. All three of the narrow bi-pointed knives (Figure 43b) are manufactured on Ouachita Mountains cherts; two are bifacially worked.

There are numerous end, side, and end-side scrapers in the Sanders site collection at the NMNH (Table 22). Side scraper comprise 57 percent of the scrapers, and 36 percent of the side scrapers have bilateral retouched/use worn areas.

Table 22. Scraping tools from the Sanders site in the NMNH collections.

\begin{tabular}{lcccc}
\hline & & \multicolumn{2}{c}{ Raw Material } & \\
Type & NOV & QTZ & OM cherts & N \\
\hline end scraper & 1 & - & 14 & 15 \\
side scraper & 2 & 1 & 23 & 26 \\
side scraper- & - & - & 15 & 15 \\
bilateral & - & - & 16 & 16 \\
end-side scraper & 3 & 1 & 68 & 72 \\
\hline Totals & & &
\end{tabular}

More than 94 percent of the scrapers are made from high quality Ouachita Mountains cherts that are available in Red River gravels (see Table 22). The remainder are made from novaculite (4 percent) and a local coarse-grained quartzite (1 percent).

There is a bifacially worked adze in the NMNH collections from the Sanders site that is made of a Ouachita Mountains brownish-gray chert. The chipped stone adze is 26 × $20.5 \times 8.0 \mathrm{~mm}$ in length, width, and thickness.

One drill/perforator is made from a local quartzite, while the others (including a drill on a micro-flake, with a $1.5 \mathrm{~mm}$ bit width) are made on Ouachita Mountains cherts. The bi-pointed drills/perforators (see 


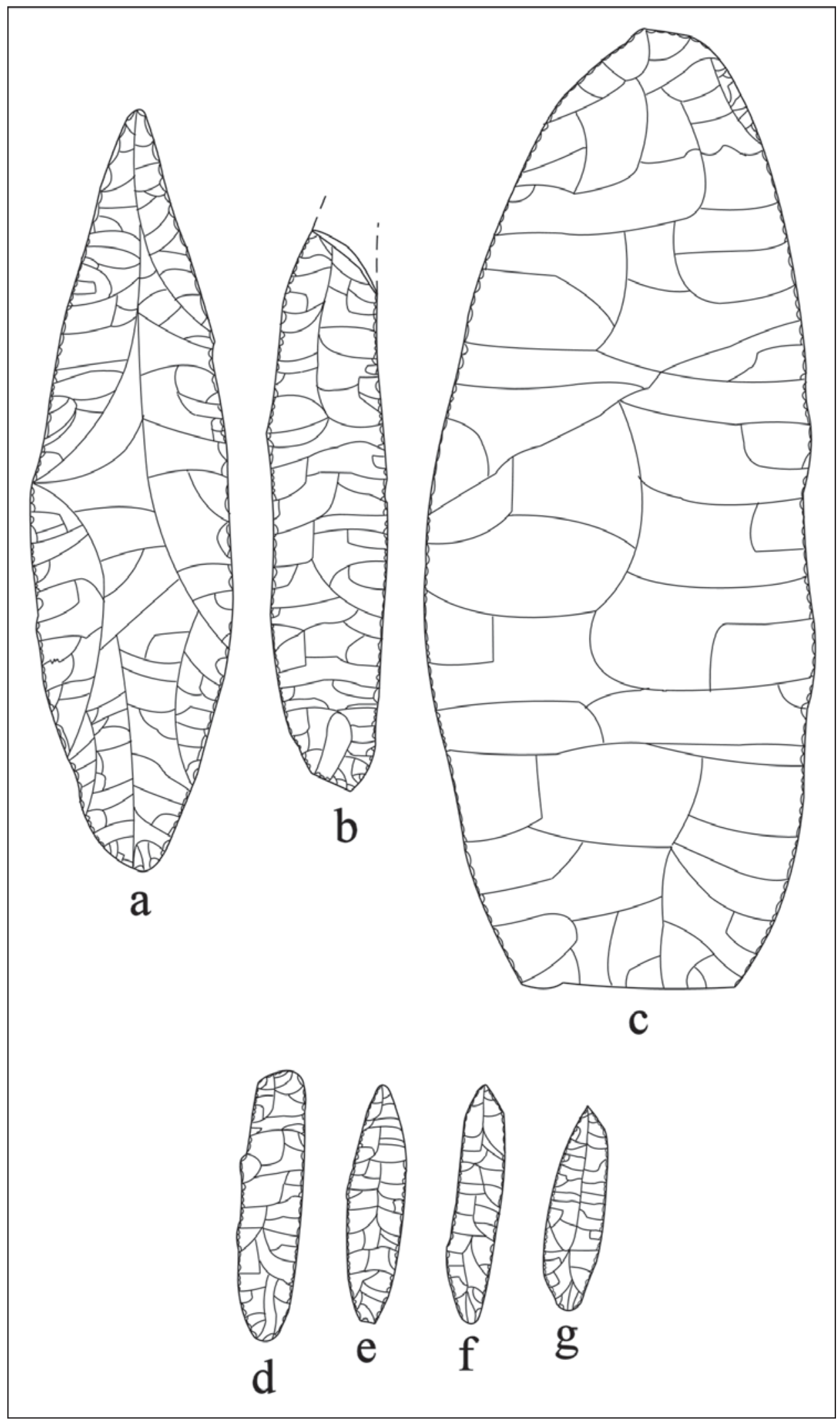

Figure 43. Chipped stone tools in the NMNH from the Sanders site: a, beveled knive; b, bi-pointed knive; c, large Central Texas blade; d-g, bi-pointed drills. 
Figure 43d-g) have either unifacial $(n=3)$ or bifacial $(n=2)$ retouching/use wear. Four are made from Ouachita Mountains cherts and one is on a local quartzite.

\section{Ground Stone Tools and Ornaments}

Ground stone tools from the Sanders site include several celts (Figure 44a-b) or celt fragments and slate gorgets. The six celts (A570667, A513224) are made from Ouachita Mountains greenstone ( $n=4)$, siliceous shale, and quartzite. These celts have polished bifacial bits. One of the celts was a funerary object in Burial 1. Other ground stone tools in the collection include abraders and a mano.

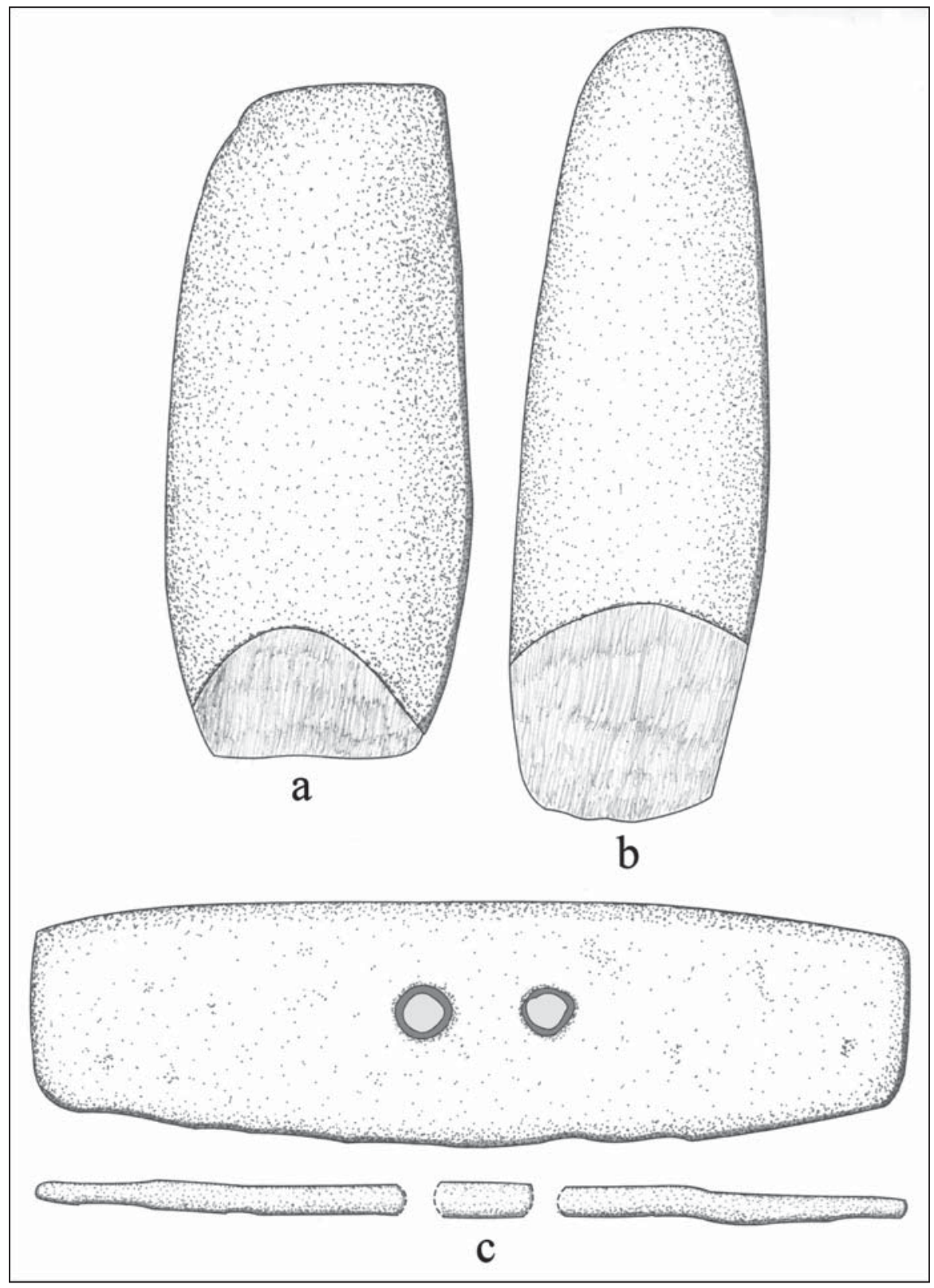

Figure 44. Ground stone tools and ornaments from the Sanders site in the NMNH collections: a-b, celts; c, gorget. 
One slate gorget was collected by Harris (1953:19) from the eastern part of the Sanders site. It has two suspension holes drilled in the center of the piece (see Figure 44c). There is a fragment of another slate gorget (A513250) in the collection.

\section{Pieces of Cooper and Turquoise}

The NMNH collections from the Sanders site include a rounded but unmodified piece of turquoise (22 x $10 \times 7 \mathrm{~mm}$ in length, width, and thickness), probably from the Cerrillos Hills source in north central New Mexico (Hull et al. 2014:Figure 1). Jurney and Young (1995:23 and Figure 6) note that a small turquoise bead, a pendant, and a piece of raw turquoise had been collected from the surface of the Sanders site by the Bill Young family; these were not found in any of the defined surface artifact clusters we have recognized at the Sanders site. There is also a $12 \times 7 \times 4 \mathrm{~mm}$ piece of copper (from the Great Lakes or the Appalachian Mountains) in the collection (A570668).

\section{Bone Tools and Bone Beads}

There are several animal bone tools in these Sanders site collections. They include two modified deer bone fragments with cut/grooved lines, two deer antler tine flaker fragments, and four deer ulna awls or awl fragments (Figure 45a-c); there are also three burned bone awl tips. There is also a bi-pointed polished bone awl or needle that is $105.5 \mathrm{~mm}$ in length, $6.0 \mathrm{~mm}$ in width, and $4.5 \mathrm{~mm}$ in thickness (Figure 45d), as well as two fish spine needles, and a notched bison bone rib (Figure 45e). The collection also has two bison scapula hoe fragments (A513239).

A few tubular and cut bone beads are in the Sanders site collections. These range from $20-31 \mathrm{~mm}$ in length and 4-6 $\mathrm{mm}$ in diameter $(\mathrm{n}=5)$ to $12-14 \mathrm{~mm}$ in length and $7-8 \mathrm{~mm}$ in diameter $(\mathrm{n}=2)$.

\section{Marine Shell Items}

Marine shell items in the Sanders site collection at the NMNH include three large (7-10 $\mathrm{mm}$ in diameter) conch shell beads, and four Olivella sp. shell beads (11-12 $\mathrm{mm}$ in length and 5-6 $\mathrm{mm}$ in diameter). About 50 conch shell beads were placed as funerary offerings in Burial 6 at the Sanders site excavated by Harris. There is also a small cut marine shell pendant about $31.9 \mathrm{~mm}$ in length, $9.9 \mathrm{~mm}$ in width, and $4.0 \mathrm{~mm}$ in thickness (Figure 46a), and two gorget fragments.

\section{Mussel Shell Items}

One mussel shell artifact is a cut piece of a mussel shell saw (see Figure 46b). The fragment is $34 \mathrm{~mm}$ in length and $3.5 \mathrm{~mm}$ in thickness. There are also three $(8-11 \mathrm{~mm}$ in diameter) large pearl beads in the collection from the site. Finally, the collection contains two mussel shell hoes and five mussel shell scrapers/shredders.

\section{European Trade Goods}

\section{Gunflint}

A single 18th century blade gunflint was examined in the NMNH collections from the Sanders site (A513220). It is made from a dark grayish-brown chert and has edge trimming on all four sides of the piece. 


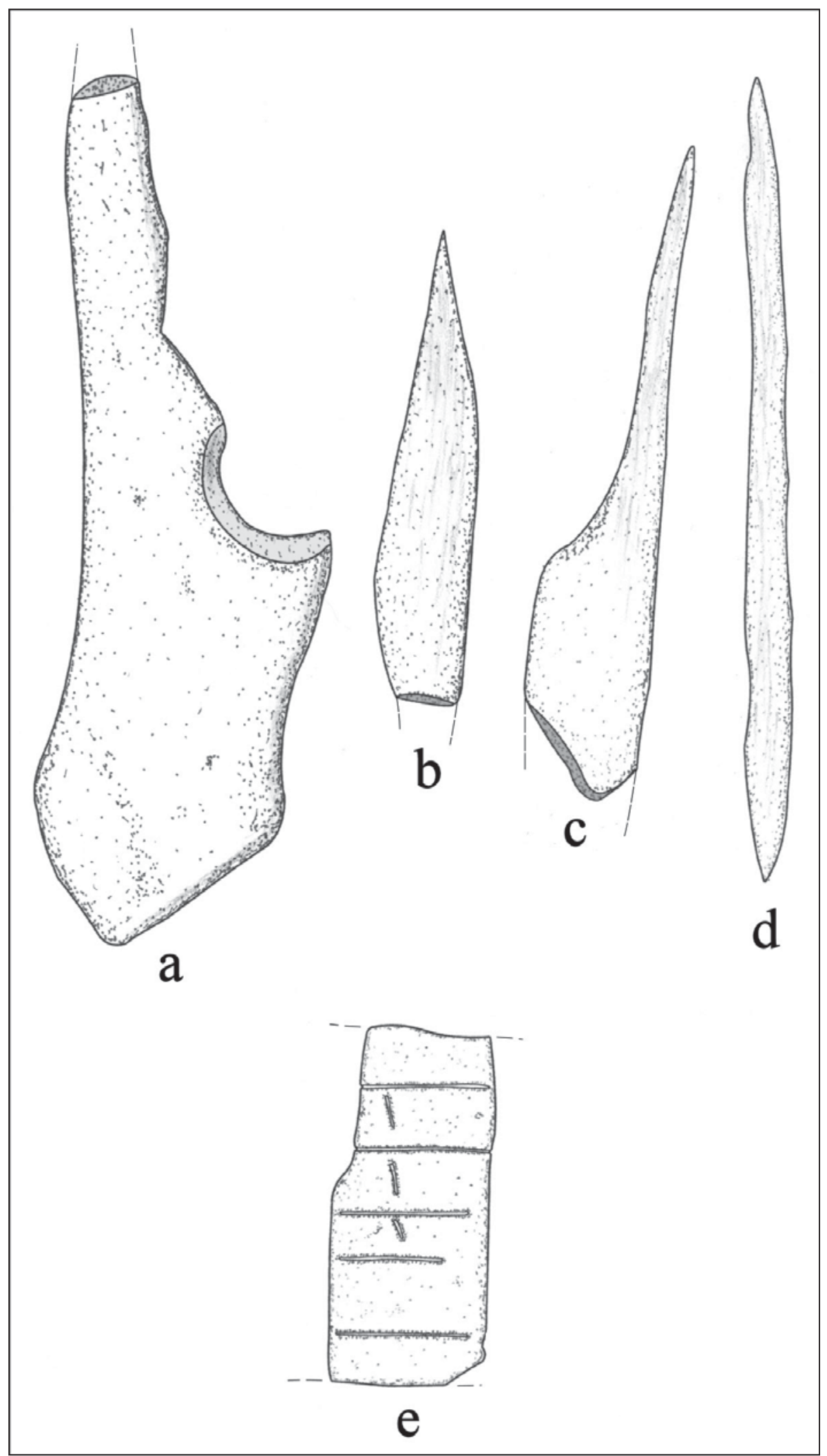

Figure 45. Bone tools from the NMNH collections from the Sanders site (41LR2). 


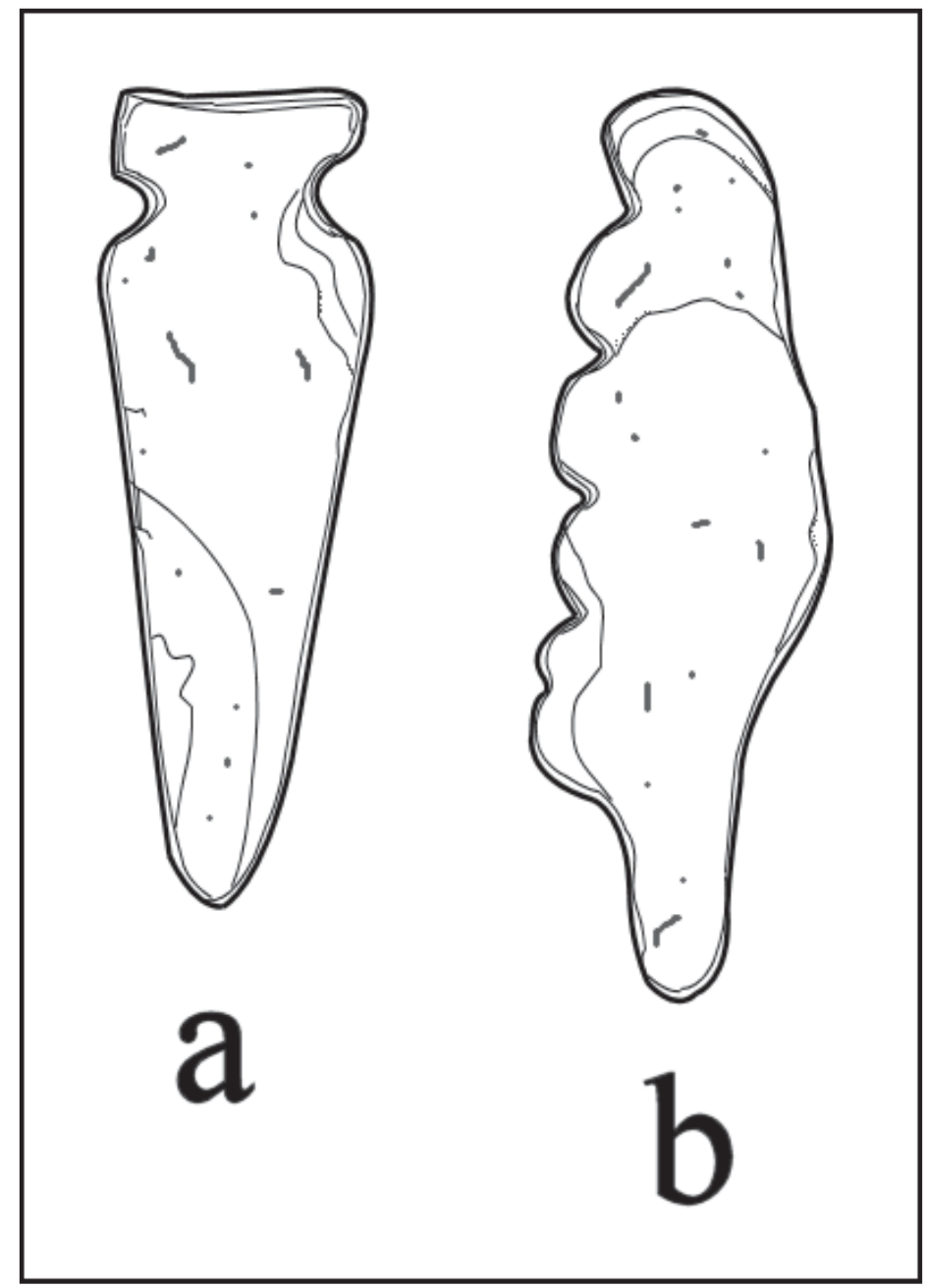

Figure 46. Marine shell and mussel shell artifacts from the NMNH collections from the Sanders site: a, marine shell pendant (A570673); b, mussel shell saw fragment (A513241).

\section{Kettle}

There is one folded and cut piece of a cupreous kettle fragment in the Long collection (A570669); it may have been part of a broken or unfinished tinkler. The piece is $29 \times 27 \mathrm{~mm}$ in length and width, and only $1.1 \mathrm{~mm}$ in thickness. The rim of another kettle is in the Harris collection (A513256).

\section{Other Trade Goods}

Other European trade goods in the NMNH collection from the Sanders site include brass tinklers $(\mathrm{n}=8)$, a one Real (1759-1788) Spanish coin, four iron spikes, and 50+ white and blue glass beads. The glass beads were strung on a necklace worn by the individual excavated by Harris that he referred to as Burial 2 .

\section{Trade Pipe}

Two white ball clay pipe sherds was found in the historic area at the Sanders site by Harris (1953:20). The bowl of one of the pipe sherds has the modeled head of a sheep or lamb. 


\section{SUMMARY AND CONCLUSIONS}

The Sanders site (41LR2) is an expansive ancestral Caddo settlement on an alluvial terrace landform near the confluence of Bois d'Arc Creek and the Red River in the Post Oak Savanna of East Texas. The site is best known for the series of single and multiple Caddo burials excavated in 1931 by The University of Texas from Mound No. 1 (East Mound) (Jackson et al. 2000; Krieger 1946), but it was understood even at that time that there were extensive habitation archaeological deposits at the site, although how these were related to Caddo mound construction, burial interments, and other mound uses had not been considered in any detail. The archaeological investigations reported on herein hope to change that perspective, because our focus has been on the character of the material culture remains found in trenching and extensive surface collections in non-mound contexts at the site, based on (1) examination of 1931 UT trenching material culture remains, (2) analysis of the various artifact collections held by The University of Texas at Austin, Texas Archeological Research Laboratory and the National Museum of Natural History at the Smithsonian Institution, most of which are comprised of surface collections, and (3) the 2014 collection (from surface investigations and limited shovel testing) and detailed analysis of well-provenienced surface artifacts from ca. 400 acres of the Sanders site on lands owned by Julia Trigg Crawford. This work has identified more than 30 distinct clusters of artifacts on the surface of the site, and these are both south and east of Mounds No. 1 and No. 2 and the midden deposits on a ridge between the two mounds (cf. Krieger 1946).

The recovered artifacts from the various analyzed assemblages collected from the Sanders site indicate that the site was occupied as early as the Late Archaic period, but there is a more substantial Woodland period component(s) marked by Gary dart points and possibly Scallorn arrow points. The first of the principal ancestral Caddo components apparent in non-mound contexts is part of the Middle Caddo period Sanders phase occupation (estimated to date from ca. A.D. 1100-1300) best known through excavations in Mounds No. 1 and No. 2. Although there is some doubt concerning the temporal extent of the last ancestral Caddo occupation at the Sanders site, our best temporal estimate is that it dates from the late 17th century to ca. A.D. 1740 .

\section{Characteristics of the Material Culture Assemblage from the Sanders Site}

The material culture assemblage from the non-mound areas at the Sanders site is dominated by sherds from plain ware, utility ware, and fine ware vessels. A total of 1126 decorated sherds are in the various collections analyzed in this article, 56.2 percent of which are from fine ware vessels and 43.8 percent are from utility wares (Table 23). The overall percentage of engraved and red-slipped fine ware sherds is substantial. In a database of 390 ceramic sherd assemblages from across East Texas (Perttula n.d.), only six assemblages have higher proportions of fine ware sherds (i.e., $>58$ percent) than do the non-mound sherd assemblages from the Sanders site. Four of these six assemblages are in the upper Sabine River basin and have components generally contemporaneous with, and stylistically comparable to, the late 17th-early 18th occupation at the Sanders site. The two remaining assemblages include an 18th century occupation at an East Texas mission (41SA25) and a late 17th century Titus phase occupation associated with a cemetery (41TT13).

The substantial proportions of fine ware vessel sherds indicates that there were apparently no spatial/intrasite or social distinctions in non-mound areas in the manufacture, use, and discard of fine ware vessels. In other words, fine ware vessels were not limited in their use to high status persons in the ancestral Caddo settlement, were not primarily made and used for mound rituals and ceremonies, and were not primarily included as funerary offerings with individuals interred in Mounds No. 1 and No. 2 at the site (cf. Krieger 1946).

Utility ware sherds are dominated by those with incised and fingernail punctated elements (see Table 23). Most of these sherds are from Canton Incised and Monkstown Fingernail Impressed vessels that are part of the Middle Caddo period, Sanders phase, occupation at the site. Lip notched Sanders Plain sherds, the pinched sherds, and the various incised-punctated sherds, can also be included with the Sanders phase 
Table 23. Decorative methods in the sherds from the various non-mound collections at the Sanders site.

\begin{tabular}{|c|c|c|}
\hline Decorative method & $\mathrm{N}$ & Percentage \\
\hline \multicolumn{3}{|l|}{ Utility ware } \\
\hline Appliqued & 28 & 2.5 \\
\hline Appliqued-incised & 1 & 0.1 \\
\hline Appliqued-punctated & 1 & 0.1 \\
\hline Brushed & 5 & 0.4 \\
\hline Brushed-Incised & 1 & 0.1 \\
\hline Corn Cob Impressed & 3 & 0.3 \\
\hline Incised & 284 & 25.3 \\
\hline Incised-Punctated & 31 & 2.8 \\
\hline Lip Notched & 9 & 0.8 \\
\hline Neck Banded & 29 & 2.6 \\
\hline Pinched & 5 & 0.4 \\
\hline Punctated, cane & 2 & 0.2 \\
\hline Punctated, circular & 16 & 1.4 \\
\hline Punctated, fingernail & 62 & 5.5 \\
\hline Punctated, tool & 16 & 1.4 \\
\hline Sub-total, utility ware & 493 & 43.8 \\
\hline \multicolumn{3}{|l|}{ Fine ware } \\
\hline Engraved & 398 & 35.4 \\
\hline Engraved-punctated & 1 & 0.1 \\
\hline Red-slipped & 217 & 19.2 \\
\hline Red-slipped-appliqued & 1 & 0.1 \\
\hline Red-slipped-punctated & 4 & 0.4 \\
\hline Trailed & 12 & 1.1 \\
\hline Sub-total, fine ware & 633 & 56.2 \\
\hline Totals & 1126 & 100.0 \\
\hline
\end{tabular}

component. Utility wares that can confidently be associated with the much later ancestral Caddo occupation include the brushed, brushed-incised, corn cob impressed, neck banded (both grog and shell-tempered varieties of Nash Neck Banded), and the shell-tempered punctated sherds (from Emory Punctated-Incised vessels).

The fine ware sherds in non-mound contexts at the Sanders site are dominated by both engraved and redslipped decorative elements (see Table 23). The Sanders phase grog- and bone-tempered fine ware ceramics are dominated by sherds from Sanders Engraved and Sanders Plain vessels.

Trailed sherds from Keno Trailed vessels, accounting for only 1.9 percent of the fine ware sherds in the collections (see Table 23), are part of the late 17th-18th century Caddo occupation, one with both grog/bonetempered Womack Engraved and shell-tempered Avery Engraved, Hudson Engraved, and Simms Engraved vessel sherds. Based on the number of sherds, Womack Engraved vessel sherds are the most abundant fine ware in non-mound contexts at the site, regardless of the age of the engraved fine wares. The grog/bonetempered scroll engraved sherds (i.e., Bois d'Arc Engraved) are likely also part of this ceramic assemblage, given their stylistic similarity to certain Womack Engraved decorative motifs, but further work is warranted to establish its temporal relationship with certainty. 
The manufacture of red-slipped vessels was common in both the Sanders phase and late 17th-early 18th century components, although the earlier red-slipped vessels were grog- and bone-tempered (Sanders Plain) while the later red-slipped sherds were from shell-tempered Clement Redware vessels. The few red-slippedpunctated sherds ( 0.6 percent, see Table 23 ) are from the punctated variety of Maxey Noded Redware vessels.

Most of the sherds from the ceramic vessels made and used at the Sanders site were tempered with grog or crushed sherds (Table 24), with a secondary use of crushed and burned bone and crushed and burned mussel shell. The shell-tempered vessel sherds are part of the late 17th-early 18th century Caddo occupation, while the use of grog and bone temper for vessel manufacture characterizes both the Sanders phase and late 17th-early 18th century Caddo settlements. This presents a considerable if not virtually insurmountable challenge at the present time in sorting out the entire grog- and bone-tempered plain and decorated sherd assemblage (at least the utility wares anyway) by component.

Table 24. Temper frequency in sherds from the various non-mound collections at the Sanders site.

\begin{tabular}{lcc}
\hline Temper & $\mathrm{N}$ & Percentage \\
\hline grog & 2075 & 75.0 \\
bone & 353 & 12.8 \\
shell & 337 & 12.2 \\
\hline Totals & 2765 & 100.0 \\
\hline
\end{tabular}

There are two forms of ceramic pipes and pipe sherds in the Sanders site material culture assemblage from non-mound contexts. The earlier form, associated with the Middle Caddo period occupation, is the Haley variety of long-stemmed Red River pipe. Long-stemmed ceramic pipes were also among the grave goods in Burials 6 and 8 in Mound No. 1 at Sanders (see Jackson et al. 2000:62, 68). The later form, part of the Historic Caddo period occupation, is the elbow pipe form. This form occurs in both plain (with a rounded elbow or lower stem) and engraved (with a stem spur) styles. The engraved elbow pipes have cross-hatched zone decorative elements as well as cross-hatched triangle elements (see Figure 42); these decorative elements are stylistically related to certain engraved motifs on Womack Engraved vessels. A sherd from a siliceous stone pipe is present in the King Harris collection from the Sanders site, along with a sherd from the bowl of a Catlinite pipe, and an L-shaped stone pipe was a funerary offering in Burial 1 (see Jackson et al. 2000:53).

Chipped stone and ground stone tools in the Sanders site collections are dominated by high-quality gray, dark brown, dark gray, very dark gray, and black Ouachita Mountains cherts that were collected in local Red River gravels. Other Ouachita Mountains lithic raw materials that were used by ancestral peoples included novaculite (also well represented in the chipped stone tools), a greenish-gray Atoka Formation quartzite, slate, greenstone, and siliceous shale. Local raw materials in the tool assemblage and collected lithic debris includes Ogallala quartzite and earth-toned cherts.

Not counting fragments, identifiable arrow points from the Sanders site outnumber dart points by a ratio of 9.4:1 (Table 25). That there are only Late Archaic (ca. 5000-2500 years B.P.) and Woodland period (ca. 2500-1150 B.P.) dart points in the extensive Sanders site collections is probably an indication of the age of the Red River alluvial terrace landform that was occupied by aboriginal peoples rather than that earlier Archaic and Paleoindian groups were not using and foraging in this part of the Red River basin. Gary dart points - the classic marker for the Woodland period in East Texas - is by far the most common Woodland period dart point style in the dart point assemblage (Table 25). Furthermore, more than 92 percent of the identifiable dart points from the Sanders site are Woodland period diagnostics. 
Table 25. Projectile points in the various collections from the Sanders site.

\begin{tabular}{lrr}
\hline Type & N & Percentage \\
\hline Arrow point & & \\
Alba & 19 & 4.9 \\
Alba/Bonham & 1 & 0.3 \\
Bonham & 12 & 3.1 \\
Cuney & 3 & 0.8 \\
Hayes & 14 & 3.6 \\
Homan/Colbert & 5 & 1.3 \\
cf. Keota & 1 & 0.3 \\
Maud-Fresno & 306 & 79.8 \\
Scallorn & 14 & 3.6 \\
Sequoyah & 1 & 0.3 \\
Washita & 9 & 2.3 \\
Sub-total & 385 & 100.0 \\
& & \\
Dart point & & \\
Woodland period styles & & \\
$\quad$ Darl & 2 & 4.9 \\
$\quad$ Kent & 3 & 7.3 \\
$\quad$ Gary & 32 & 7.4 \\
$\quad$ Trinity & 1 & 100.0 \\
$\quad$ Late Archaic styles & 3 & \\
$\quad$ Sub-total & 41 & \\
\hline
\end{tabular}

Of the earlier stemmed arrow point styles represented in the collections from the Sanders site, the Alba, Bonham (also found in burial contexts, see Jackson et al. 2000, Burial 2, Burial 4, and Burial 5 materials), Hayes, and Scallorn types are most common (see Table 25); similar corner-notched and expanding stem arrow points were recovered in Burials 4, 5, and 19 in Mound No. 1 at Sanders (see Jackson et al. 2000). The late 17th-early 18th century arrow points at the Sanders site include the Cuney, Washita, and triangular Maud-Fresno points with concave or flat bases. The Maud-Fresno points comprise 80 percent of the arrow points in the collection (see Table 25). One side-notched arrow point resembling a Washita point was recovered in Burial 14 in Mound No. 1 (see Jackson et al. 2000:78).

Among the other chipped stone tools in the various collections from the Sanders site, both flake tools $(n=73)$ and scrapers $(n=121)$ are quite common, but it is likely that the number of flake tools is significantly underrepresented in the assemblages because flakes were not commonly collected from the site except in the 2014 investigations. There are end scrapers, side scrapers with one or two working edges, and end-side scrapers. Other chipped stone tools from the site include drills, bi-pointed drills (also found in Middle Caddo period burials at the site, Burial 1, see Jackson et al. 2000:53), perforators, a denticulate, gouges, adzes, beveled knives and bi-pointed knives, and a large Central Texas biface blade.

Ground stone tools in the assemblage are less varied than the chipped stone tools. They include celts (also found in Middle Caddo Burial 12, see Jackson et al. 2000), slate gorgets, abraders, and mano/pitted stones.

There are also several kinds of bone tools in the TARL and NMNH collections from the Sanders site, including awls, needles, and bison scapula hoes; such hoes were found in Burial 20 as well as midden contexts 
at the site (see Jackson et al. 2000:67, 78-79). Bone awls are also found in Middle Caddo burials (Burials 6 and 9), and a bone needle was one of the grave goods in Burial 18 at the Sanders site (see Jackson et al. 2000:62, 69, and 85).

There are also marine shell and mussel shell artifacts from surface contexts in settlement areas at the Sanders site. These include marine shell pendants, shell gorgets, conch shell beads (from Burial 6 excavated by R. King Harris at the site), Olivella sp. beads, pearl beads, mussel shell hoes, scrapers, and a mussel shell saw. It is suspected, although it cannot be demonstrated on the basis of available evidence, that these marine shell and mussel shell artifacts are associated with the Middle Caddo period occupation at Sanders, given the abundance of marine shell beads $(n=5203)$, conch shell dippers and whole conch shells $(n=5)$, pendants and discs $(n=16)$, and gorgets $(n=22)$ in burials of that age at the site (see Jackson et al. 2000:40-49).

\section{Late Archaic and Woodland Period components}

The Sanders site was not heavily used by aboriginal peoples during the Late Archaic and Woodland periods. The evidence for occupation during these periods, between ca. 5000 B.P. and ca. 1150 B.P., is limited to (at present) various dart points and biface preforms (discarded before dart points could be completed). The fact that Gary points are by far the most common dart point type in the assemblage (see Table 25) indicates that the Sanders site was used by aboriginal peoples more often during the Woodland period, perhaps primarily for hunting activities, than during the preceding Late Archaic period.

\section{Middle Caddo Period component}

The Middle Caddo period component at the Sanders site represents the type site of the Sanders phase (or focus) as first defined by Krieger (1946:201-218). In formulating the character of the Sanders phase, Krieger focused on the burials and funerary offerings excavated in Mound No. 1 (East Mound) by UT in 1931, as well as artifacts recovered in the midden deposits in Mound No. 1 and the saddle between Mounds No. 1 and No. 2. Krieger (1946:201) noted that "the surface collections are almost wholly distinct from the grave and midden artifacts, and represent other known culture complexes;" these materials are part of the late 17 th-early 18 th century component discussed in this article.

The Middle Caddo period component in non-mound contexts is extensive, indicating that there was a substantial population living at the Sanders site and that the site was not simply a mound center and cemetery for the burial of high status individuals in Mound No. 1. The ceramic assemblage that can be associated with this component, which is estimated (roughly) to date from ca. A.D. 1100-1300 (see Bruseth 1998), includes both the utility wares Canton Incised and Monkstown Fingernail Impressed and the fine wares Sanders Engraved, Sanders Plain, and Maxey Noded Redware. There are also long-stemmed Red River clay pipes, and Alba, Bonham, and Hayes arrow points (see Table 25).

\section{Late 17th-Early 18th Century component}

Trade goods from European sources are one of the key material culture categories present in the final ancestral Caddo occupation at the Sanders site. These materials have been found in at least one burial excavated by R. King Harris, as well as from surface contexts in occupation areas well south of the two mounds at the Sanders site. European trade goods found at Sanders include gunflints, glass beads (from the surface and from Burial 2 excavated by King Harris), metal kettle pieces, white ball clay trade pipe sherds, brass tinklers, a 1774 Spanish coin (obviously from what may have been the latest ancestral Caddo occupation of the site), and iron spikes. Aboriginal materials thought to be associated with these European trade goods include the many triangular arrow points (Maud-Fresno) in the collections, as well as probably most of the 
scraping tools. The abundance of hunting tools and scrapers at the Sanders site strongly suggests that the Caddo inhabitants were heavily invested in the procurement and processing of hides (deer and bison) for the burgeoning fur trade. Also included in the material culture assemblage for this component are plain and decorated elbow pipes along with the well-represented plain and decorated shell-tempered pottery - including the utility wares Nash Neck Banded and Emory Punctated-Incised and the fine wares Avery Engraved, Hudson Engraved, and Simms Engraved, as well as Clement Redware-and the grog- and bone-tempered Womack Engraved vessel sherds; Womack Engraved is the principal fine ware type. Radiocarbon dates, and perhaps also TL dates on diagnostic decorated ceramic sherds recovered in controlled subsurface contexts, are very much needed to establish the beginning age of this component, as it is important to determine if this occupation by Caddo peoples had already been established at the site prior to the appearance and their adoption of European trade goods, as well as how long this occupation was in place before it was abandoned.

\section{FUTURE PROSPECTS}

With the permission of the Crawford family, further archaeological research at the Sanders site is planned to better understand its intra-site character, the nature of each of the surface artifact clusters, and the age range of the principal ancestral Caddo occupations. As it stands at the moment, this archaeological research will consist of several inter-related parts:

- the completion of an extensive geophysical survey (i.e., primarily utilizing the magnetometer) of the habitation areas at the site, with the purpose of identifying geophysical anomalies that can be correlated with ancestral Caddo structures, midden deposits, other kinds of cultural features, and any courtyard/plaza areas;

- additional controlled surface collections at each of the defined surface artifact clusters, and the identification of any new artifact clusters, in the areas south and east of Mounds No. 1 and No. 2. Such surface collections will bolster the sample sizes of the material culture assemblages from the defined surface artifact clusters, thereby permitting ready comparisons of their functional, stylistic, and temporal character;

- completing a series of shovel tests within each of the defined surface artifact clusters, so as to assess their subsurface archaeological character and identify midden deposits below the plow zone, as well as determine the potential for cultural features to be preserved in the different artifact clusters;

- and excavate a series of $1 \times 1 \mathrm{~m}$ units in the defined surface artifact clusters that are assessed as having a good potential for cultural feature preservation and abundant ancestral Caddo material culture remains, including animal bone and plant remains. These excavations will be designed to identify cultural features in the archaeological deposits, thus shedding light on the occupational character of the surface artifact clusters; recover controlled samples of material culture remains in the archaeological deposits; and obtain dateable organic remains from known archaeological contexts at the site for AMS radiocarbon dating of ancestral Caddo habitation areas at the Sanders site.

\section{ACKNOWLEDGMENTS}

We are very grateful for the support of our continuing archaeological investigations at the Sanders site provided by the landowner, Julia Trigg Crawford. We also appreciate access to the Sanders site collections at the Texas Archeological Research Laboratory, The University of Texas (TARL), provided by Ardi Karlter and Jonathan Jarvis. Dorothy Lippert of the Repatriation Office in the National Museum of Natural History, Smithsonian Institution (NMNH), arranged access to the King Harris and Joseph Long collections from the Sanders site in the NMNH. Ed Jelks provided useful information on the probable location of the Historic Caddo archaeological deposits at the Sanders site. 


\section{END NOTES}

1. The analytical worth of Krieger (2000) may be called into question, most particularly by Krieger, himself, who wrote on the first page of the typescript study on file at TARL - subsequently published after his death - that "This is a piece of foolishness \& not to be used as reference by anyone---the author 1-8-40."

\section{REFERENCES CITED}

Allen, G. L., Jr., P. Allen, J. F. Cochran, L. F. Duffield, R. E. Forrester, Jr., E. D. Helm, I. R. Lobdell, D. Lubell,

R. E. Padgett, and R. L. Tapscott

1967 Stone Tools. In "The Gilbert Site: A Norteno Focus Site in Northeast Texas," edited by E. B. Jelks. Bulletin of the Texas Archeological Society 37:191-211.

Bell, R. E., E. B. Jelks, and W. W. Newcomb (assemblers)

1967 A Pilot Study of Wichita Indian Archeology and Ethnohistory. Final Report for Grant GS-964, National Science Foundation, Washington, D.C.

Brown, J. A.

1996 The Spiro Ceremonial Center. The Archaeology of Arkansas Valley Caddoan Culture in Eastern Oklahoma. 2 Vols. Memoir No. 29. Museum of Anthropology, University of Michigan, Ann Arbor.

Bruseth, J.E.

1998 The Development of Caddoan Polities along the Middle Red River Valley of Eastern Texas and Oklahoma. In The Native History of the Caddo: Their Place in Southeastern Archeology and Ethnohistory, edited by T. K. Perttula and J. E. Bruseth, pp. 47-68. Studies in Archeology 30. Texas Archeological Research Laboratory, The University of Texas at Austin.

Bruseth, J. E., D. E. Wilson, and T. K. Perttula

1995 The Sanders Site: A Spiroan Entrepot in Texas? Plains Anthropologist 40(153):223-236.

Chelf, C.

1939 A Group Burial from Lamar County. Information Circular No. 6. Texas Memorial Museum, Austin.

Duffield, L. F. and E. B. Jelks

1961 The Pearson Site: A Historic Indian Site at Iron Bridge Reservoir, Rains County, Texas. Archaeology Series No. 4. Department of Anthropology, The University of Texas at Austin.

Emerson, T. E. and R. E. Hughes

2000 Figurines, Flint-Clay Sourcing, the Ozark Highlands, and Cahokian Acquisition. American Antiquity 65(1):79-101 .

Emerson, T. E., R. E. Hughes, M. R. Hymes, and S. R. Wisseman

2003 The Sourcing and Interpretation of Cahokia-Style Figurines in the Trans-Mississippi South and Southeast. American Antiquity 68(2):287-313.

Flynn, P.

1976 A Study of Red-Filmed Pottery from the Clement Site (Mc-8), McCurtain County, Oklahoma. Bulletin of the Oklahoma Anthropological Society 25:127-134.

Hamilton, D. L.

1997 Observations on Caddoan Burial Practices at the Sanders Site (41LR2). Bulletin of the Texas Archeological Society 68:115-134. 
Hanna, H., Jr.

1950 Three Burials from Mound 2, T. M. Sanders Site. The Record 8(4):16-19. Dallas Archeological Society, Dallas.

Harris, R. K.

1953 Two Recent Trips to Sites in Fannin and Lamar Counties. The Record 11(5):19-20. Dallas Archeological Society, Dallas.

Harris, R. K. and I. M. Harris

1967 Trade Beads, Projectile Points, and Knives. In A Pilot Study of Wichita Indian Archeology and Ethnohistory, assembled by R. E. Bell, E. B. Jelks, and W. W. Newcomb, pp. 129-162. Final report for Grant GS-964, National Science Foundation, Washington, D.C.

Harris, R. K., I. M. Harris, J. C. Blaine, and J. Blaine

1965 A Preliminary Archeological and Documentary Study of the Womack Site, Lamar County, Texas. Bulletin of the Texas Archeological Society 36:287-363.

Hoffman, M. E.

1967 Ceramic Pipe Style Chronology Along the Red River Drainage in Southwestern Arkansas. The Arkansas Archeologist 8(1):4-14.

Housewright, R.

1940 A Multiple Burial in Lamar County. The Record 2(8):37-39. Dallas Archeological Society, Dallas.

Hull, S., M. Fayek, F. J. Mathien, and H. Roberts

2014 Turquoise trade of the Ancestral Puebloan: Chaco and beyond. Journal of Archaeological Science 45:187195.

Jackson, A. T.

n.d. Laboratory Study of the Material Culture, T. M. Sanders Site, Lamar County, Texas. MS on file, Texas Archeological Research Laboratory, The University of Texas at Austin.

Jackson, A. T., M. S. Goldstein, and A. D. Krieger

2000 The 1931 Excavations at the Sanders Site, Lamar County, Texas: Notes on the Fieldwork, Human Osteology, and Ceramics. Archival Series 2. Texas Archeological Research Laboratory, The University of Texas at Austin.

Jurney, D. H. and W. Young

1995 Southwestern Pottery and Turquoise in Northeastern Texas. Caddoan Archeology Newsletter 6(2):15-28.

Krieger, A. D.

1946 Culture Complexes and Chronology in Northern Texas, with Extensions of Puebloan Datings to the Mississippi Valley. Publication No. 4640. The University of Texas, Austin.

2000 The Pottery of the Sanders Farm. In The 1931 Excavations at the Sanders Site, Lamar County, Texas: Notes on the Fieldwork, Human Osteology, and Ceramics, by A. T. Jackson, M. S. Goldstein, and A. D. Krieger, pp. 131-144. Archival Series 2. Texas Archeological Research Laboratory, The University of Texas at Austin.

2009 Archaeological Horizons in the So-Called Caddo Area. Archival Series 3. Texas Archeological Research Laboratory, The University of Texas at Austin.

Lohse, J. C., S. L. Black, and L. M. Cholak

2014 Toward an Improved Archaic Radiocarbon Chronology for Central Texas. Bulletin of the Texas Archeological Society 85:251-279. 
Maples, W. R.

1962 A Morphological Comparison of Skeletal Material from Sanders Focus and from Fulton Aspect. Master's thesis, Department of Anthropology, The University of Texas at Austin.

Pearce, J. E. and A. T. Jackson

1931 Notes on Field Work T. M. Sanders Farm, Lamar County, Texas, July 23 to August 29, 1931. MS on file, Texas Archeological Research Laboratory, The University of Texas at Austin.

Perttula, T. K.

1997 Sabine River and Middle Red River Ceramics: Musings on the Ceramic Data used in Schambach's "Continuing the Discussion of the Spiroans and Their Entrepots." Caddoan Archeology 8(3):9-18.

2011 The Ceramic Artifacts from the Lang Pasture Site (41AN38) and the Place of the Site within an Upper Neches River Basin Caddo Ceramic Tradition. In Archeological Investigations at the Lang Pasture Site (41AN38) in the Upper Neches River Basin of East Texas, assembled and edited by T. K. Perttula, D. B. Kelley, and R. A. Ricklis, pp. 145-320. Archeological Studies Program Report No. 129, Texas Department of Transportation, Environmental Affairs Division, Austin.

2013 Analysis of a Small Sample of Caddo Ceramic Sherds from the T. M. Sanders Site (41LR2), Lamar County, Texas. Journal of Northeast Texas Archaeology 39:1-5.

n.d. East Texas Caddo Ceramic Sherd Database. Journal of Northeast Texas Archaeology 51, in press.

Perttula, T. K. and P. S. Marceaux

2011 Archeological Survey Investigations on the Crawford Property and a Portion of the T. M. Sanders Site (41LR2) in the New Proposed Right-of-Way for the Keystone XL Pipeline, Lamar County, Texas. Letter Report No. 280. Archeological \& Environmental Consultants, LLC, Austin.

Perttula, T. K., B. Nelson, and M. Walters

2014 Renewed Archaeological Investigations at the Sanders Site (41LR2), Lamar County, Texas. Journal of Northeast Texas Archaeology 47:25-30.

Perttula, T. K., M. B. Trubitt, and J. S. Girard

2012 The Use of Shell-Tempered Pottery in the Caddo Area of the Southeastern United States. Southeastern Archaeology 30(2):242-267.

Peyton, A.

2013 Interim Report: Results of Archaeological Significance Testing at the Sanders Site (41LR2), Lamar County, Texas. SWCA Environmental Consultants, Austin.

Ressel, D.

1979 Soil Survey of Lamar and Delta Counties, Texas. United States Department of Agriculture, in cooperation with Texas Agricultural Experiment Station, Washington, D.C.

Rodning, C. B.

2014 Cherokee Towns and Calumet Ceremonialism in Eastern North America. American Antiquity 79(3):425443.

Schambach, F. F.

1995 A Probable Spiroan Entrepot in the Red River Valley in Northeast Texas. Caddoan Archeology Newsletter 6(1):9-25.

1998 Pre-Caddoan Cultures of the Trans-Mississippi South. Research Series 53. Arkansas Archeological Survey, Fayetteville.

1999 Deconstructing the "Sanders Focus" and "Sanders Phase": A Reply to Perttula Regarding the Taxonomy and Significance of the So-Called Sanders Focus, or Sanders Phase Pottery of Northeast Texas and Southeast Oklahoma. Caddoan Archeology 9(3-4):3-55. 
2000a The Significance of the Sanders Site in the Culture History of the Mississippi Period Southeast and the Southern Plains. In The 1931 Excavations at the Sanders Site, Lamar County, Texas: Notes on the Fieldwork, Human Osteology, and Ceramics, by A. T. Jackson, M. S. Goldstein, and A. D. Krieger, pp. 1-7. Archival Series 2. Texas Archeological Research Laboratory, The University of Texas at Austin.

2000b Spiroan Traders, the Sanders Site, and the Plains Interaction Sphere: A Reply to Bruseth, Wilson, and Perttula. Plains Anthropologist 45(171):17-33.

Story, D. A., B. Barber, E. Cobb, H. Cobb, R. Coleman, K. Gilmore, R. K. Harris, and N. Hoffrichter

1967 Pottery Vessels. In "The Gilbert Site: A Norteno Focus Site in Northeast Texas," edited by E. B. Jelks. Bulletin of the Texas Archeological Society 37:112-187.

Suhm, D. A. and E. B. Jelks (editors)

1962 Handbook of Texas Archeology: Type Descriptions. Special Publication No. 1, Texas Archeological Society, and Bulletin No. 4, Texas Memorial Museum, Austin. Reprinted in 2009, Gustav's Library, Davenport, Iowa.

Teltser, P. A.

1993 An Analytic Strategy for Studying Assemblage-Scale Ceramic Variation: A Case Study from Southeast Missouri. American Antiquity 58(3):530-543.

Wilson, D.

1993 The Sexual Division of Labor at the Sanders Site (41LR2), Lamar County Texas. Caddoan Archeology Newsletter 4(3):6-13.

1994 Division of Labor and Stress Loads at the Sanders Site (41LR2), Lamar County, Texas. Bulletin of the Texas Archeological Society 65:129-160.

1995 Dental Paleopathologies in the Sanders Site (41LR2) Population from Lamar County. Journal of Northeast Texas Archaeology 5:29-59.

1997 Dental Paleopathology in the Sanders (41LR2) and Mitchell (41BW4) Populations from the Red River Valley, Northeast Texas. Bulletin of the Texas Archeological Society 68:147-159.

Wilson, D., and D. Cargill

1993 Stable Isotope Analysis from the Sanders Site (41LR2). Caddoan Archeology Newsletter 4(3):3.

Wilson, D., and S. Derrick

1996 Cranial Modeling Among the Caddo. The Newsletter of the Friends of the Texas Archeological Research Laboratory 4(2):20-21.

Wilson, L.

1948 Two Small Pipes from the Sanders Site near Direct. The Record 6(7):30. Dallas Archeological Society, Dallas.

Wilson, L., and R. Housewright

1941 Scrapers from Sanders Site, Lamar County. The Record 3(4):19-21. Dallas Archeological Society, Dallas. 